\title{
25. GEOCHEMISTRY OF TETRAPYRROLE, TETRATERPENOID, AND PERYLENE PIGMENTS IN SEDIMENTS FROM THE GULF OF CALIFORNIA: DEEP SEA DRILLING PROJECT LEG 64, SITES 474, 477, 479, AND 481, AND SCRIPPS INSTITUTION OF OCEANOGRAPHY GUAYMAS BASIN SURVEY CRUISE LEG 3, SITES 10G AND 18G1
}

\author{
Earl W. Baker and J. William Louda, Organic Geochemistry Group, Florida Atlantic University, Boca Raton, Florida
}

\begin{abstract}
Results and discussion cover pigment analyses of 36 sediment samples recovered by Deep Sea Drilling Project Leg 64, and six samples from the Leg 64 site-survey cruise in the Guaymas Basin (Scripps Institution of Oceanography, Leg 3). Pigments investigated were tetrapyrroles, tetraterpenoids, and the PAH compound perylene.

Traces of mixed nickel and copper ETIO-porphyrins were ubiquitous in all sediment samples, except for the very surface (i.e., $<2 \mathrm{~m}$ sub-bottom), and their presence is taken as an indication of minor influxes of previously oxidized allochthonous (terrestrial) organic matter.

Phorbides and chlorins isolated from Site 479 sediment samples (i.e., the oxygen-minimum locale, northeast of the Guaymas Basin) well represent the reductive diagenesis ("Treibs Scheme"; see Baker and Palmer, 1978; Treibs, 1936) of chlorophyll derivatives. Three forms of pheophytin-a, plus a variety of phorbides, were found to give rise to freebase porphyrins, nickel phylloerythrin, and nickel porphyrins, with increasing depth of burial (increasing temperature).

Sediments from Sites $481,10 \mathrm{G}$, and $18 \mathrm{G}$ yielded chlorophyll derivatives characteristic of early oxidative alterations. Included among these pigments are allomerized pheophytin-a, purpurin-18, and chlorin- $\mathrm{p}_{6}$.

The high thermal gradient imposed upon the late Quaternary sediments of Site 477 greatly accelerated chlorophyll diagenesis in the adjacent overlying sediments, that is, the production of large quantities of free-base desoxophylloerythroetioporphyrin (DPEP) occurred in a section (477-7-5) presently only 49.8 meters sub-bottom. Present depth and age of these sediments are such that only chlorins and phorbides would be expected.

Carotenoid (i.e., tetraterpenoids) concentrations were found to decrease rapidly with increasing sub-bottom depth. Less deeply buried sediments (e.g., 0-30 m) yielded mixtures of carotenes and oxygen-substituted carotenoids. Oxygencontaining (oxy-, oxo-, epoxy-) carotenoids were found to be lost preferentially with increased depth of burial.

Early carotenoid diagenesis is suggested as involving interacting reductions and dehydrations whereby dehydro-, didehydro-, and retro-carotenes are generated. Destruction of carotenoids as pigments may involve oxidative cleavage of the isoprenoid chain through epoxy intermediates, akin to changes in the senescent cells of plants.

Perylene was found to be a common component of the extractable organic matter from all sediments investigated. The generation of alkyl perylenes was found to parallel increases in the existing thermal regime at all sites. Igneous sills and sill complexes within the sediment profile of Site 481 altered (i.e., scrambled) the otherwise straightforward thermally induced alkylation of perylene.

The degree of perylene alkylation is proposed as an indicator of geothermal stress for non-contemporaneous marine sediments.
\end{abstract}

\section{INTRODUCTION}

A total of 42 core samples collected by DSDP Leg 64 and Leg 3 of the SIO Guaymas Basin Site Survey were analyzed for tetrapyrrole, tetraterpenoid, and perylene pigments.

The transformation of biotic chlorophyll into the relatively stable geologic pigments, the metalloporphyrins, is the main area of our continuing investigation. To that end, the large sample suite obtained from the oxygenminimum site (479) northeast of the Guaymas Basin, together with near-surface sediments $(0-1.5 \mathrm{~m}$ sub-bottom) from the Guaymas Basin site survey (SIO Leg 3, Sites $10 \mathrm{G}$ and $18 \mathrm{G}$ ) have afforded us the unique opportunity of examining organic-rich diatomaceous sediments which were deposited under reducing conditions. Though these studies are continuing, the preliminary data presented herein indicate that within the sediment profile at Site 479 the entire reductive diagenesis of chlo-

\footnotetext{
${ }^{1}$ Curray, J. R., Moore, D. G., et al., Init, Repts. DSDP, 64: Washington (U.S. Govt. Printing Office).
}

rophyll, except for the generation (release?) of vanadyl porphyrins, is present.

Samples from Sites 474, 477, 481, 10G, and 18G, presently at about 0.1 to 50 meters sub-bottom, yielded tetrapyrrole pigments characteristic of early oxidative diagenesis, as forwarded during the study of Japan Trench sediments (DSDP Legs 56 and 57; Baker and Louda, 1980a; Louda et al., 1980).

The tetraterpenoid pigments (i.e., carotenoids) are very prone to oxidative destruction, whether in vitro (Liaaen-Jensen, 1971), within senescent tissue (Chichester and Nakayama, 1965; Simpson et al., 1976), or in surface sediments (Fox, 1948). Further loss of tetraterpenoids, as pigments, may involve reduction (Watts and Maxwell, 1977), metabolism by benthic or infaunal organisms (Fox, 1948; Fox et al., 1944), and thermal degradation (Day and Erdman, 1963). Thus, given that carotenoids are relatively more prone to removal from the fossil record than are the chlorophyll derivatives, proposals which attempt to correlate these two pigment classes as diagenetic (especially paleoenvironmental) markers are forwarded. Enhanced preservation of both tetrapyrrole and tetraterpenoid pigments was found to 
coincide in upper Pliocene and Quaternary diatomaceous and siliceous silty clays from the San Miguel Gap, California (DSDP Leg 63, Site 467; Louda and Baker, 1981).

The presence of alkylated perylenes in marine sediment has been noted by several authors (Aizenshtat, 1973; Brassel et al., 1980; Louda and Baker, 1981). In the previous study we suggested that in marine sediments with relatively stable profiles (i.e., lack of significant reworking) the degree of perylene alkylation is directly related to the thermal history of the host setting (Louda and Baker, 1981). In the present study, the alkylated perylenes again have been found to increase in abundance in response to the imposed thermal regime. Further, Site 481 sediments, in which "normal" heat flow has been interrupted by the emplacement of several sills (see site chapters, this volume), yielded a rather haphazard trend in perylene alkylation patterns. Thus, the degree of perylene alkylation is proposed as an organic indicator of geothermal stress for marine sedimentary bitumen (cf. Baker and Louda, 1981).

\section{MATERIALS AND METHODS}

Detailed description of the analytical procedures employed during the present study have been presented elsewhere (Louda and Baker, 1981). Purification of metalloporphyrins was achieved by low-pressure liquid-chromatography (1.p.l.c.) over 13 to $24 \mu \mathrm{m}$ silica (Whatman LPS-1), rather than $175-\mu \mathrm{m}$ alumina, as in the previous report (cf. Louda and Baker, 1981).

Selected isolates, thought to contain conjugated carbonyl functions, were submitted to sodium borohydride $\left(\mathrm{NaBH}_{4}\right)$ reduction in ethanol for carotenoids, or $20 \%$ ethanol in diethyl ether for tetrapyrrole pigments, as before (Baker and Louda, 1980a; Louda and Baker, 1981). Discussion of the utility of $\mathrm{NaBH}_{4}$ in the analyses of carotenoids (Krinsky and Goldsmith, 1960; Liaaen-Jensen, 1971) and chlorophyll derivatives (Holt, 1959) appears elsewhere, as indicated.

Electronic absorption spectra were recorded with a Perkin-Elmer model 575 instrument, coupled to a Perkin-Elmer model C570-0729 derivative function accessory and calibrated with holmium oxide. Mass spectra were determined with a DuPont 21-491B instrument, as detailed elsewhere (Louda and Baker, 1981).

Quantitation of the three classes of studied pigments was based upon electronic spectroscopy, using the extinction coefficients and molecular weights given in Table 1 .

Chromatography over microcrystalline cellulose with increasing percentages of acetone in petroleum ether (b.p. $30-60^{\circ} \mathrm{C}$ ) afforded separation of crude pigment extracts into three main fractions. Fraction 1 , eluted with 0 to $5 \%$ acetone in petroleum ether, contained pheophytins, non-polar (i.e., phytylated or decarboxylated) phorbides, decarboxylated free-base and metalloporphyrins, carotenoids, and perylene. Fraction 2, eluted with 15 to $25 \%$ acetone in petroleum ether, contained the mono-carboxylic tetrapyrroles such as pheophorbide-a. Fraction 3, eluted with 50 to $100 \%$ acetone in petroleum ether, contained the polar chlorins (i.e., di- and tri-carboxylic acids). Separation of known chlorophyll derivatives (e.g., pheophytin-a, pheophorbide-a and chlorin- $\mathrm{e}_{6}$ ) proved these designations correct.

The structures of various tetrapyrrole and tetraterpenoid pigments are given as Appendices A and B, respectively.

Since others have implicated the formation of metallochlorins (Hodgson and Peake, 1961) or the transformation of copper-chlorins and copper-porphyrins into nickel or vanadyl porphyrins (Galimov et al., 1980) during the diagenesis of chlorophyll, a series of copper phorbides and copper porphyrins have been synthesized. Authentic pheophorbide-a (IV), pheophytin-b, chlorin-e 6 -TME (XVII), desoxomesopyropheophorbide-a (XII), desoxophylloerythrin-ME, and etioporphyrin-I were reacted with cupric sulfate, according to published methods (Jones et al., 1968). In essence, the tetrapyrrole in acetone has added to it a $1 / 4$ volume of $1 \mathrm{M}$ aqueous $\mathrm{CuSO}_{4}\left(\mathrm{CuCl}_{2}\right.$ in Jones et al., 1968); a few crystals of ascorbic acid were added, the reaction vessel was flushed with nitrogen, and the mixture was stirred in the dark at room temperature for 1 to $1 \frac{1}{2}$ hours. At the end of the reaction period, the acetone was removed with a stream of nitrogen, water was added, and the pigments were transferred to ethyl ether. Unreacted starting material was removed by extraction into an appropriate percentage of ice-cold aqueous $\mathrm{HCl}$ (see Smith, 1975). Only in the case of copper desoxomesopyropheophorbide-a ME (CuDOMPPaME) was a further chromatographic purification required. In this case, exposure of CuDOMPP-a ME to acid and atmospheric oxygen apparently caused aromatization, forming $\mathrm{Cu}$ desoxophylloerythrinME (CuDPE-ME) as a by-product. This product, CuDPE-ME, was removed from CuDOMPP-a-ME by l.p.l.c. over silica (described earlier), using isocratic elution with $2 \%$ acetone in petroleum ether. CuDOMPP-a-ME eluted first as a blue band, followed by CuDPE. $\mathrm{ME}$ as a red-to-magenta band.

A variety of authentic carotenoid pigments were obtained from commercial sources or were isolated from well-documented natural sources, as follows (see Straub, 1971 for structures; see also Appendix A for certain structures designated by roman numerals): $\beta$-carotene (XXII; $\beta, \beta$-carotene) was purchased from Carl Roth Laboratories, West Germany; echinenone (XXVIII; $\beta, \beta$-caroten-4-one) and canthaxanthin (XXIX; $\beta, \beta$-carotene-4, $4^{\prime}$-dione) were the generous gifts of F. Hoffman-LaRoche, Basel, Switzerland; isocryptoxanthin (XXX; $\beta, \beta$-caroten-4-ol) and isozeaxanthin $(\beta, \beta$-carotene-4,4' -diol) were prepared by the borohydride reduction of echinenone and canthaxanthin, respectively; lutein $\left(\beta, \Sigma\right.$-carotene-3, $3^{\prime}$-diol) and violaxanthin (zeaxanthin diepoxide; $5,6,5^{\prime}, 6^{\prime}$-diepoxy-5,6,5',6'-tetrahydro- $\beta, \beta$-carotene$3,3^{\prime}$-diol) were isolated from common spinach (Spinacea oleracea); and trans- and cis-fucoxanthin (XXXV; 5,6-epoxy-3,3',5'-trihydroxy$6^{\prime}, 7^{\prime}$-didehydro- $5,6,7,8,5^{\prime}, 6^{\prime}$-hexa-hydro- $\beta, \beta$-caroten-8-one-3' ${ }^{\prime}$-acetate) were isolated from the brown alga Sargassum sp., obtained locally.

Authentic tetrapyrrole pigments were formed from pheophytin-a (ex Spinacea oleracea chlorophyll-a, or purchased from Roth Laboratories, West Germany) according to published methods (Baker et al., 1968; Fischer and Stern, 1940; Fuhrhop and Smith, 1975).

\section{RESULTS AND DISCUSSION}

The geochemistry of chlorophyll derivatives, carotenoids, and perylene pigments was investigated in a total of 42 core samples from the Gulf of California.

Sample descriptions and pigment-yield data are presented as Table 2 . Analytical bias in the present study was given to the tetrapyrrole pigments; by this, we imply that absolute totals of carotenoid pigments may be to the low side of reality, because of co-elution of certain tetrapyrrole and tetraterpenoid pigments. We feel, however, that the trends and products of carotenoid geochemistry reported herein are representative and do not vary in quantitation by more than about $5 \%$.

The three classes of pigments (tetrapyrroles, tetraterpenoids, perylene) will be discussed in turn, followed by a section in which we attempt to unravel the geochemistry of each.

\section{Tetrapyrrole Pigments}

The diagenesis of chlorophyll derivatives is well documented within the sample suites examined from the present Gulf of California investigation. Results are especially significant within the various strata recovered at Site 479 , the oxygen-minimum site bordering the northeast Guaymas Basin.

\section{Pigment Yield}

Definite trends in tetrapyrrole pigment yield, both absolute and as a fraction of organic carbon (i.e., pigment yield index, PYI; see Table 2, footnote h), can be noted from examination of the data in Table 2. Within 
Table 1. Extinction coefficients and molecular weights of tetrapyrrole, tetraterpenoid, and perylene pigments.

\begin{tabular}{|c|c|c|c|c|}
\hline Pigment Class Compound & $\begin{array}{l}\text { Extinction }{ }^{\mathrm{a}} \\
\text { Coefficient }\end{array}$ & $\begin{array}{l}\text { Wavelength }{ }^{b} \\
(\mathrm{~nm})\end{array}$ & $\begin{array}{l}\text { Molecular Weight }{ }^{\mathrm{C}} \\
\text { (atomic mass units) }\end{array}$ & $\begin{array}{l}\text { Leg } 64 \text { tsolates } \\
\text { for Which These } \\
\text { Values Were Employed }\end{array}$ \\
\hline \multicolumn{5}{|l|}{ Tetrapyrrole } \\
\hline Pheophytin-a & $a=63.7^{e}$ & 667 & 870 & $\begin{array}{l}\text { Cellulose fraction } 1 \text {, } \\
\text { pheophytin-a }\end{array}$ \\
\hline Pheophorbide-a & $\Sigma_{\mathrm{m}} M=52.76^{\mathrm{e}}$ & 667 & 590 & $\begin{array}{l}\text { Cellulose fraction 2, } \\
\text { pheophorbides }\end{array}$ \\
\hline Chlorin-e6 & $\Sigma_{\mathrm{m} M}=53.25^{\mathrm{e}}$ & 665 & 596 & $\begin{array}{c}\text { Cellulose fraction } 3 \text {, } \\
\text { polar chlorins }\end{array}$ \\
\hline Octaethylchlorin & $\Sigma_{\mathrm{m}} M=73.2^{\mathrm{e}}$ & $\lambda_{\max }$ & $\begin{array}{l}\quad 480 \\
\text { (i.c., octa-methyl- } \\
\text { octa-ethyl-chlorin) }\end{array}$ & $\begin{array}{l}\text { Chlorins-636,-641: } \\
\text { Phorbides } \\
641 / 646.8\end{array}$ \\
\hline Desoxophylloerythrin & $\Sigma_{\mathrm{m}} M=6.54^{\mathrm{e}}$ & 619 & (i.e., C-32 DPEP) & Free-base porphyrins \\
\hline Ni Phylloerythrin & $\Sigma=1.7 \times 10^{4 f}$ & 589 & $\begin{array}{c}546 \\
\text { (i.e., C. } 32 \text { NiPE) }\end{array}$ & $\mathrm{Ni}$ phylloerythrin \\
\hline $\mathrm{Cu}$ and $\mathrm{Ni}$ Octaethylorphyrin & $\Sigma_{\mathrm{m}} M=29.9$ (avg.) $)^{e}$ & 550 & (i.e., C-32 NiDPEP) & Metalloporphyrins \\
\hline \multicolumn{5}{|l|}{ Tetraterpenoid } \\
\hline$\beta$-Carotene & $\left.E\right|_{\mathrm{cm}} ^{\%}=2592^{8}$ & 449 & 536 & $\beta$-carotene \\
\hline Echinenone & $\left.E\right|_{\mathrm{cm}} ^{\% \%}=2158^{8}$ & 455 & 550 & echinonone \\
\hline Cryptoxanthin & $\left.E\right|_{\mathrm{cm}} ^{\%}=2460^{8}$ & 452 & 552 & - \\
\hline Isozeoxanthin & $\left.E\right|_{\mathrm{cm}} ^{\%}=2400^{3}$ & 450 & 568 & - \\
\hline "Carotene-like" & $\left.E\right|_{\mathrm{cm}} ^{\%}=2500$ & $\lambda_{\max }$ & 536 & mixed carotenes \\
\hline "Carotenol-like" & $\left.E\right|_{\mathrm{cm}} ^{\%}=2400$ & $\lambda_{\max }$ & 552 & carotenols \\
\hline "Carotenone-like" & $\left.E\right|_{\mathrm{cm}} ^{\%}=2200$ & $\lambda_{\max }$ & 550 & carotenones \\
\hline "Carotene-diol-like" & $\left.E\right|_{\mathrm{cm}} ^{\%}=2400$ & $\lambda_{\max }$ & 568 & $\begin{array}{l}\text { carotene-diols and } \\
\text { epoxy-diols }\end{array}$ \\
\hline \multicolumn{5}{|l|}{ Polyaromatic hydrocarbon } \\
\hline Perylene & $\Sigma_{\mathrm{m}} M=40.0^{\mathrm{h}}$ & $\begin{array}{c}434.0 \\
(439.5)\end{array}$ & 252 & perylene(s) \\
\hline \multicolumn{5}{|c|}{ 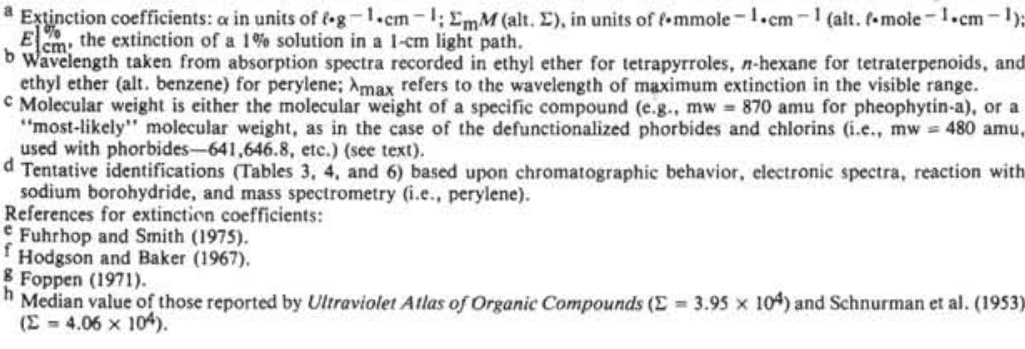 } \\
\hline
\end{tabular}

the near-surface sediments examined from Leg 3 of the Guaymas Basin Site Survey cruise (Sites 10G and 18G; see Table 2, footnote a) rapid losses of chlorophyll derivatives were found. At Site $10 \mathrm{G}$, only about half of the tetrapyrrole pigment, normalized to organic carbon (i.e., PYI), remains at $18.7 \mathrm{~cm}$, compared to the value obtained at $4.9 \mathrm{~cm}$. Site $10 \mathrm{G}$ is very close to DSDP Holes 481 and 481A, whereas Site $18 \mathrm{G}$ is nearer Site 477.

Comparing pigment yields and loss rates for chlorophyll derivatives between Sites $10 \mathrm{G}$ and 481/481A, and between $18 \mathrm{G}$ and 477 , we find that changes in either sedimentation or depositional environment have occurred between the time at which shallow sediments (i.e., recovered at less than 2 meters sub-bottom: Sites 10G, 18G) and the deeper DSDP core samples (Sites 477 and 481 ) were deposited.

Though no quantitative sedimentological study was performed on the site-survey samples studied here, Sample 18G-V appears to contain more coarse-grained material (sands) which most likely led to increased oxygenation of this sample during its early postdepositional history. Thus, if we ignore Sample 18G-V, the loss of tetrapyrrole pigment within Sites $18 \mathrm{G}$ and 477 , above the sill at 58 meters sub-bottom (see site reports, this volume, Pt. 1, hereafter "this volume"), is straightforward.

Comparisons between Sites $10 \mathrm{G}$ and 481/481A, again only to the region of the first (i.e., shallowest) igneous intrusion $(\sim 170 \mathrm{~m}$ sub-bottom; see site reports, this volume) indicate that the portion of organic carbon composed of chlorophyll derivatives has undergone temporal changes within the sediments spanning 0.049 to 47.5 meters sub-bottom. The largest PYI value obtained to date for tetrapyrrole pigments in marine sediments is just under 50, for Section 481-2-2 (see Table 2). Evidently, input of autochthonous material to this stratum was especially high and affected by little, if any, dilution by previously oxidized (especially terrestrial) organic materials.

Tetrapyrrole pigment loss within sediments recovered at Sites $\mathbf{4 7 4}$ and $\mathbf{4 7 9}$ is more reminiscent of the trends we observe in settings with moderate heat flow and free from igneous intrusive events.

Presented as Figure 1 is a comparison of the alteration in chlorophyll derivatives, normalized to organic carbon (i.e., PYI: cf. Table 2, footnote h) for Sites 10G, 18G, and 477, 474/474A, and 479. Site 10G (Fig. 1A) 
Table 2. Sample description and pigment yields, DSDP Leg 64.

\begin{tabular}{|c|c|c|c|c|c|c|c|c|}
\hline \multirow[b]{2}{*}{$\begin{array}{c}\text { Sample }{ }^{\mathrm{a}} \\
\text { (interval in } \mathrm{cm} \text { ) }\end{array}$} & \multirow[b]{2}{*}{$\begin{array}{c}\text { Deptha } \\
\text { (m sub-bottom) }\end{array}$} & \multirow[b]{2}{*}{ Lithologic Description ${ }^{b}$} & \multicolumn{6}{|c|}{$\begin{array}{l}\text { Pigment Yield } \\
\text { (\% dry wt.) }\end{array}$} \\
\hline & & & $\begin{array}{c}\text { Organic } \\
\text { Carbon } \\
\text { (\%o dry wt.) }\end{array}$ & $\begin{array}{l}\text { Water } \\
\text { Content } \\
(\%)\end{array}$ & $\begin{array}{c}\text { Tetrapyrrolec } \\
\text { (dominant class) } \\
(\mathrm{A} / \mathrm{g} / \mathrm{g})\end{array}$ & $\begin{array}{c}\text { Carotenoid }{ }^{f} \\
(\mu \& / g)\end{array}$ & $\begin{array}{c}\text { Perylene } 8 \\
(\mu g / g)\end{array}$ & $\begin{array}{c}\text { Tetrapyrroleh } \\
\text { PYI }\end{array}$ \\
\hline $10 \mathrm{G}-3,3.9-5.9$ & 0.049 & Olive-brown, hemipelagic, diatomaceous, clayey ooze & 2.58 & 87.6 & $69.500(\mathrm{Chl})$ & $+(?)$ & $+(?)$ & 26.94 \\
\hline $10 \mathrm{G}-5,7.9-9.8$ & 0.088 & Olive-brown, hemipelagic, diatomaceous, clayey ooze & 2.94 & 82.0 & $48.687(\mathrm{Chl})$ & $+(?)$ & $+(?)$ & 16.56 \\
\hline $10 \mathrm{G}-7,11.8-13.8$ & 0.128 & Olive-brown, hemipelagic, diatomaceous, clayey ooze & 3.73 & 75.6 & 55.453 (Chl) & $+(?)$ & $+(?)$ & 14.85 \\
\hline $10 \mathrm{G}-10,17.7-19.7$ & 0.187 & Olive-brown, hemipelagic, diatomaceous, clayey ooze & 1.04 & 51.5 & 14.732 (Chl) & 1.388 & 0.032 & 14.14 \\
\hline 18G-I, 1-10 & 0.050 & Olive-brown, hemipelagic, diatomaceous, clayey ooze & 3.03 & 83.6 & 51.786 (Chl) & $+(?)$ & $+(?)$ & 17.10 \\
\hline 18G-v, $100-170$ & 1.650 & Olive-brown, hemipelagic, diatomaceous, clayey ooze & 2.13 & 76.4 & 3.054 (Chl) & $+(?)$ & $+(?)$ & 1.41 \\
\hline $\begin{array}{l}474-2-3,120-150 \\
474-17-6,100-125\end{array}$ & $\begin{array}{r}6.2 \\
153.2\end{array}$ & Dusky-yellow-green, muddy, diatomaceous nannofossil ooze & 2.2 & $\begin{array}{l}49.5 \\
33.2\end{array}$ & $\begin{array}{l}6.946(\mathrm{Chl}) \\
0.497(\mathrm{Chl}+\mathrm{MPH})\end{array}$ & $\begin{array}{c}0.836 \\
\text { n.d. }\end{array}$ & $\begin{array}{l}1.742 \\
0.487\end{array}$ & $\begin{array}{l}3.16 \\
0.31\end{array}$ \\
\hline $474 \mathrm{~A}-7-2,110-140$ & 153.2 & Dusky-yellow-green, diatomaceous nannofossil silt (incl, turbidites) & 1.6 & 35.2 & $0.497(\mathrm{Chl}+\mathrm{MPH})$ & n.d. & 0.487 & 0.31 \\
\hline $474 \mathrm{~A}-28-2,120-150$ & 223.1 & Grayish-olive-green, clayey silt & 1.4 & $37^{\circ}$ & $0.242(\mathrm{MPH})$ & n.d. & 0.089 & 0.17 \\
\hline $474 \mathrm{~A}-32-2,120-150$ & 413.2 & Grayish-olive, clayey siltstone (incl, turbidites and muds) & 1.7 & 14.4 & 0.033 (MPH) & n.d. & $<0.001$ & 0.02 \\
\hline $474 \mathrm{~A}-41-3,120-150$ & $\begin{array}{l}451.2 \\
538.3\end{array}$ & $\begin{array}{l}\text { Olivergray, silty claystone (microofractured) } \\
\text { Grayish-olive-black, silty claystone }\end{array}$ & $\begin{array}{l}1.9 \\
0.7\end{array}$ & $\begin{array}{l}19.6 \\
24.9\end{array}$ & $\begin{array}{l}0.171(\mathrm{MPH}) \\
0.082(\mathrm{MPH})\end{array}$ & $\begin{array}{l}\text { n,d. } \\
\text { n.d. }\end{array}$ & $\begin{array}{l}0.118 \\
0.001\end{array}$ & $\begin{array}{l}0.09 \\
0.12\end{array}$ \\
\hline $477-5-1,120-140$ & 30.7 & Grayish-olive, diatomaceous ooze & 2.6 & 61.6 & 21.017 (Chl) & 3.054 & 0.935 & 8.08 \\
\hline $477-7-1,132-142$ & 49.7 & $\begin{array}{l}\text { Olive-gray, nannofossil-bearing, diatomaceous coze (incl. turbidites, } \\
\text { sands) }\end{array}$ & 1.8 & $50^{*}$ & $9.764(\mathrm{FB})$ & n.d. & n.d.(?) & 5.42 \\
\hline $477-16-5,58-88$ & 121.6 & Brownish-gray, clayey siltstone & 0.7 & 35.8 & n.d. - & n.d. & (?) & - \\
\hline $477-20-1,115-135$ & 154.1 & Dark-grayish-black, carbonaceous claystone (incl. coaly fragments) & 1.4 & 20.0 & n.d. - & n.d. & (?) & - \\
\hline $479-3-2,110-130$ & 15.0 & Olive-brown, diatomaceous mud & 2.8 & $75^{\circ}$ & 41.052 (Chl) & 25.434 & 5.244 & 14.66 \\
\hline $479-5-3,125-150$ & 35.6 & Olive-brown, muddy, diatomaceous ooze & 2.7 & 67.2 & 21.937 (Chl) & 8.968 & 4.527 & 8.12 \\
\hline $479 \cdot 7-5,110-140$ & 57.6 & Olive-brown, muddy, diatomaceous ooze & 2.7 & 64.0 & $28.478(\mathrm{Chl})$ & 9.696 & 3.637 & 10.55 \\
\hline $479-9-2,115-140$ & 72.0 & Olive-brown, diatomaceous mud & 3.0 & $65.2 \mathrm{X}$ & 8.404 (Chl) & 1.701 & 10.995 & 2.80 \\
\hline $479-13-1,110-140$ & 108.6 & Olive-brown, muddy, diatomaceous ooze & 2.9 & 66.8 & 9.343 (Chl) & 0.137 & 3.369 & 3.22 \\
\hline $479-15-5,110-140$ & 133.6 & Grayish-olive, muddy, diatomaceous ooze & 2.9 & 63.6 & 16.484 (Chl) & 1.774 & 7.323 & 5.68 \\
\hline $479-17-5,120-150$ & 156.6 & Olive-brown, muddy, diatomaceous ooze & $2.8 \mathrm{X}$ & 67.4 & 15.398 (Chl) & 0.034 & 17.075 & 5.50 \\
\hline $479-19-5,115-140$ & 171.6 & Olive-brown, muddy, diatomaceous ooze & $2.7 \mathrm{X}$ & 50.8 & 7.128 (Chl) & 0.028 & 4.394 & 2.64 \\
\hline $479-22-5,110-140$ & 200.1 & Olive-brown, muddy, diatomaceous ooze & 2.6 & 44.8 & $1.890(\mathrm{Chl}>\mathrm{FB})$ & n.d. & 1.184 & 0.73 \\
\hline $\begin{array}{l}479-27-4,120-150 \\
479-29-5\end{array}$ & 246.1 & Olive-brown, muddy, diatomaceous ooze & 2.5 & 48.8 & $1.794(\mathrm{Chl}+\mathrm{FB})$ & n.d. & 1.088 & 0.72 \\
\hline $\begin{array}{l}479-29-5,120-150 \\
479-34-5,110-140\end{array}$ & 268.2 & Brownish, muddy, diatomaceous ooze & 2.6 & 47.1 & $1.527(\mathrm{Chl}>\mathrm{PH})$ & n,d. & 2.263 & 0.59 \\
\hline $\begin{array}{l}479-34-5,1110-140 \\
499-37.5,130-140\end{array}$ & 314.1 & Olive-gray, muddy, diatomaceous ooze & 3.0 & 46.8 & $1.766(\mathrm{PH}>\mathrm{Chl})$ & n.d. & 3.336 & 0.59 \\
\hline $\begin{array}{l}479-93-3,130-140 \\
499-39-4,110-140\end{array}$ & 342.8 & Grayish-olive, diatomaceous, silty clay & 2.8 & 61.4 & 0.929 (FB > MPH) & n.d. & 8.227 & 0.33 \\
\hline & $\begin{array}{l}360.1 \\
393.7\end{array}$ & Grayish-olive, diatomaceous, mud-ooze & 3.5 & $\begin{array}{l}53.6 \\
40.8\end{array}$ & $\begin{array}{l}1.188 \text { (FB }>M P H) \\
1561(\mathrm{FB}>\mathrm{MPHO}\end{array}$ & n.d. & $\begin{array}{l}9.805 \\
5.192\end{array}$ & $\begin{array}{l}0.34 \\
0.60\end{array}$ \\
\hline $\begin{array}{l}479-43-1,120-140 \\
479-47-4,110-140\end{array}$ & $\begin{array}{l}343.7 \\
436.1\end{array}$ & $\begin{array}{l}\text { Grayish-olive, ,iatomaceous, mud } \\
\text { Olive-gray claystone }\end{array}$ & $\begin{array}{l}2.6 \\
1.2\end{array}$ & $\begin{array}{l}40.8 \\
24.5\end{array}$ & $\begin{array}{l}1.561(\mathrm{FB}>\mathrm{MPH}) \\
0.958(\mathrm{MPH}>\mathrm{FB})\end{array}$ & $\begin{array}{l}\text { n.d. } \\
\text { n.d. }\end{array}$ & $\begin{array}{l}5.192 \\
0.952\end{array}$ & $\begin{array}{l}0.60 \\
0.76\end{array}$ \\
\hline $481-2-2,125-150$ & 7.6 & Olive-gray, diatomaceous ooze $(\sim 1 \mathrm{~m}$ below redox boundary) & 1.4 & $72^{\circ}$ & $69.520(\mathrm{Chl})$ & d.n.a. & d.n.a. & 49.66 \\
\hline $481-8 \cdot 2,110-140$ & 36.1 & $\begin{array}{l}\text { Olive-brown, muddy, diatomaceous ooze } \\
\text { Olater boundary }\end{array}$ & 1.7 & 47.2 & $21.752(\mathrm{Chl})$ & 1.610 & $+(x)$ & 12.80 \\
\hline $481-11-1,125-150$ & 47.5 & $\begin{array}{l}\text { Light-olive-gray, diatomaceous, silty clay (part of turbidite } \\
\text { sequence) }\end{array}$ & 1.1 & 43.4 & $22.094(\mathrm{Chl})$ & $+(\pi)$ & $+(x)$ & 20.08 \\
\hline $481 \mathrm{~A}-8-2,110-150$ & 111.1 & Grayish-olive, diatomaceous ooze-mud & 2.0 & 45.6 & $0.045(\mathrm{MPH})$ & n.d. & 2.126 & 0.02 \\
\hline $481 \mathrm{~A}-10-2,110-150$ & 130.1 & Olive-gray, diatomaceous mud & 1.3 & 41.5 & $0.037(\mathrm{MPH})$ & n.d. & 1.002 & 0.03 \\
\hline $481 \mathrm{~A}-13-6,0-14$ & 163.5 & Brownish-black, fissile claystone & 1.4 & 30.8 & n.d. - & n.d. & ind. $(\boldsymbol{x})$ & - \\
\hline $481 \mathrm{~A}-22-4,122-150$ & 247.2 & Dark-yellow-brown, diatomaceous mudstone & 2.5 & 49.4 & $0.291(\mathrm{MPH}>\mathrm{FB})$ & n.d. & 3.901 & 0.12 \\
\hline $481 \mathrm{~A}-24-5,110-140$ & 267.6 & Olive-gray, silty claystone & 1.3 & 31.6 & $0.020(\mathrm{MPH})$ & n.d. & 0.526 & 0.02 \\
\hline $481 \mathrm{~A}-26-5,120-150$ & 286.7 & Olive-gray, diatomaceous, silty claystone & 1.4 & 30.8 & $0.033(\mathrm{MPH})$ & n.d. & 1.088 & 0.02 \\
\hline $481 \mathrm{~A}-30-5,110-140$ & 324.6 & $\begin{array}{l}\text { Light-olive-brown, diatomaceous mudstone (part of turbidite } \\
\text { sequence) }\end{array}$ & 1.1 & 34.9 & $0.075(\mathrm{MPH})$ & n.d. & 2.538 & 0.07 \\
\hline
\end{tabular}

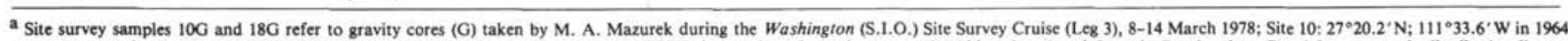
meters water depth; Site $18: 27^{\circ} 0.9^{\prime} \mathrm{N} ; 111^{\circ} 21.5^{\prime} \mathrm{W}$ in 2009 meters water depth. DSDP designations from site summaries (this volume) and Organic Geochemistry Panel frozen-sample distribution list. b $10 \mathrm{G}$ and $18 \mathrm{G}$, generalized description after similar samples reported by Simoneit et al. (1979). DSDP sample descriptions from site summaries (this volume).

$\mathrm{c}_{1} 10 \mathrm{G}$ and $18 \mathrm{G}$, organic carbon determined by the courtesy of $\mathrm{K}$. S. Schorno, Phillips Petroleum. DSDP samples organic-carbon values determined by B. R. T. Simoneit (X $=$ extrapolated from nearest sample). d Percent water reflects wet, occluded, and adsorbed water (i.e., excludes true water of hydration), deter mined for replicate aliquots by drying at $106-108^{\circ} \mathrm{C}$ for $18 \mathrm{hr}$, and repeated until stable $\left({ }^{\circ}=\right.$ from site summaries, this volume; $\mathrm{X}=$ extrapolated).

e Total tetrapyrrole pigment determined as follows: Chlorin dominated (Chl); the sum of individual fractions from cellulose chromatography. Fraction 1 eluted with 0-5\% acetone in petroleum ether and composed of phytyl esters and decarboxylated derivatives of 7-proprionic porphyrins and dihydroporphyrins; Fraction 2 eluted with 15-25\% acetone in petroleum ether, essentially only mono-carboxylic chlorophyll derivatives; Fraction 3 eluted with 100\% acetone plus traces of methanol, di- and poly-carboxylic pigments ("polar chlorins") added with subsequent isolates of free-base and metalloporphyrins. Porphyrin dominated (Ph); the sum of all isolates of phorbides, chlorins, free-base porphyrins, and metalloporphyrins (Cu, Ni) and nickel phylloerythrin (cf. Table 2). Calculations based on the following co-

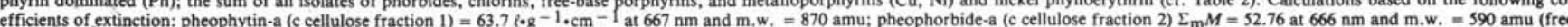
acid); chlorin-e (cellulose fraction 3) $\Sigma_{\mathrm{m}} M=53.25$ at $665 \mathrm{~nm}$ and m.w. $=569 \mathrm{amu}$ (free acid); desoxophylloerythrin (c free-base porphyrins) $\Sigma_{\mathrm{m}} M=6.54$ at $619 \mathrm{~nm}$ and $\mathrm{m}$.w. $=476$ amu (for DPEP); nickel mesoporphyrins-1X (c metalloporphyrins) $\Sigma_{\mathrm{m}} M=34.82$ at $550-560 \mathrm{~nm}$ and $\mathrm{m}$. $\mathrm{w} .=532$ amu (for $\mathrm{C}-32$ NiDPEP); nickel phylloerythrin, $\Sigma_{\mathrm{m}} M=17.1$ (cf. Hodgson and Baker, 1967 ) and m.w. $=546$ amu (for C-32 NiPE). Values from Fuhrhop and Smith (1975), except as noted. Ethyl ether solvent. Abbreviation code: n.d. = none detected, $+=$ present, ()$=$ value not determined, ind. $=$ indicated, d.n.a. $=$ data not available, sample ruined.

f Total carotenoid determined by summing individual yields of all isolates. Carotene-like spectra, $\left.E\right|_{\mathrm{cm}} ^{\%}=2500$, and m.w. $=536$ amu (carotenes, m.w. $=552$ (caroten-ols), m.w. $=568$ (carotene-diols); caroten-

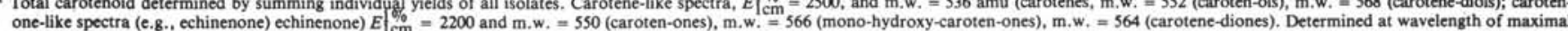
extinction in $n$-hexane solvent.

8 Total perylene equals sum of all isolates. $\Sigma_{\mathrm{m}} M=40.0$ (median value of extinction coefficients reported by Schnurmann et al., 1953, and Atlas of Ultra-Violet Spectroscopy, Vol. 10.

h PYI, pigment yield index, determined by dividing percent organic carbon into the yield of tetrapyrrole pigment expressed in $\mu \mathrm{g}$ per $\mathrm{g}$ sediment (ef., Louda et al., 1980), both values being taken on a dry-weight basis (cf., Baker and Louda, 1980b).

data (cf. Table 2) indicate an approximately $50 \%$ loss of tetrapyrrole pigment within the first 0.2 meters of sediment accumulation. Rapid loss of chlorophyll derivatives from the fossil record is attributed to oxidative destruction of the tetrapyrrole chromophore (both herein and previously; cf. Baker and Louda, 1980a, b; Louda et al., 1980; Orr et al., 1958). The profile of pigment yield (PYI) versus depth obtained for Site 10G (Fig. 1A) indicates that loss of tetrapyrrole during diagenesis occurs with two major inflections, or "break-points," rather than just one, as forwarded previously (Baker and Louda 1980a,b). That is, in the uppermost sediments (e.g., 0-2 m, sub-bottom) oxidation and the oxicto-anoxic shift appear to govern the amount of chloro- phyll derivatives (i.e., intact phorbides) available for continued diagenesis within underlying anoxic sediments. Following this initial period of rapid oxidation, the continued loss of tetrapyrrole pigments more likely appears to be governed by the action of anaerobic biota, strict reductive chemistries, and increasing thermal stress, as found for the Japan Trench sediments (DSDP Leg 56; Baker and Louda, 1980a). During this second phase, as discussed in the following section, defunctionalization of phorbides occurs. The third phase of diagenesis begins once in situ temperatures have become high enough to cause aromatization of phorbides to free-base porphyrins, and chelation of the latter with metal (e.g., $\mathrm{Ni}$. 

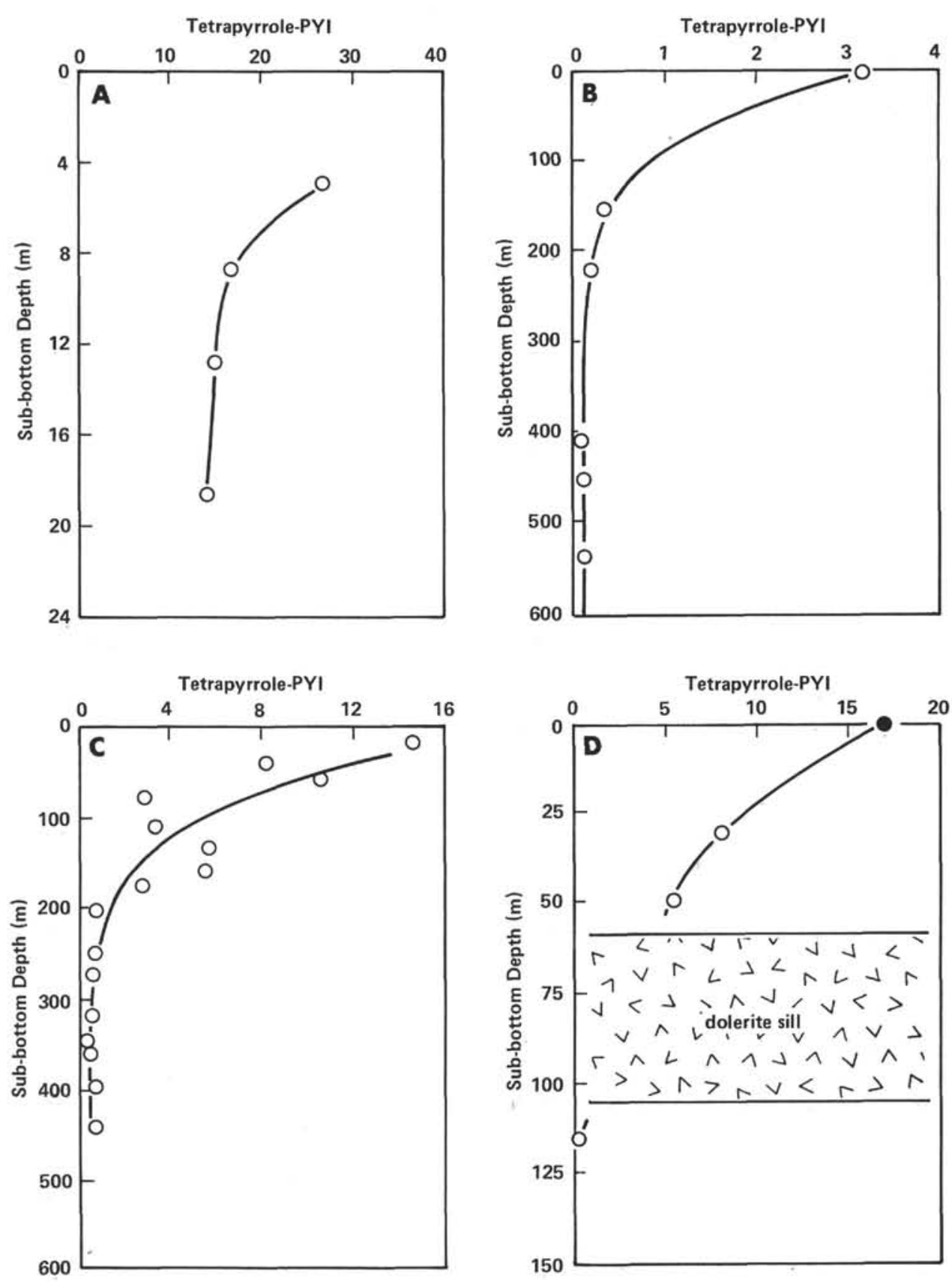

Figure 1. Pigment yield index versus sub-bottom depth for DSDP Leg 64 sample suites. A. Site 10G, SIO site survey. B. Holes 474/474A. C. Site 479. D. Site 18G (solid circle), SIO site survey, and Site 477. PYI defined as a unitless value obtained by dividing pigment yield in $\mu \mathrm{g}$ sediment, dry, by the percent organic carbon, dry, of the sediment.)

Using the foregoing scenario, interpretation of pigment-yield trends obtained from other sites becomes possible. Holes 474/474A yielded the tetrapyrrole-yield profile given as Figure 1B. Again, rapid loss is noted in the uppermost strata; however, it must be pointed out that even the initial PYI values are low (e.g., 3.16 for 474-2-3; see Table 2 and Fig. 1B) which indicates extremely strong oxidation of autochthonous chlorophyll, input of previously oxidized organic matter, or both. Because Holes 474/474A are located at the base of a submarine fan (see site reports, this volume), we feel that prolonged oxidation of chlorophyll derivatives through resedimentation has occurred. Further, a minor influx of terrestrially derived material is indicated by copper porphyrins in trace amounts within these sediments (cf. Louda and Baker, 1981; Palmer and Baker, 1978).

Data from analyses of Site 479 sediments (Fig. 1C) show that loss of tetrapyrrole pigment, as a portion of the organic carbon, essentially ceases at about 200 meters sub-bottom, and that this cessation coincides with the beginning of active aromatization, which yields porphyrins (see Table 2). Fluctuations in pigment loss from 15 to 150 meters sub-bottom are attributed to both 
seasonal and long-term alterations in initial deposition, that is, the relative inputs of autochthonous versus allochthonous organic matter and oxicity of depositional environments (see site reports, this volume).

Sites $18 \mathrm{G}$ and 477 yielded the combined profile given as Figure 1D, if one ignores Sample 18G-V, as discussed above. Here, the rapid loss of tetrapyrrole pigment is seen to tend toward that point where stabilization might have occurred; however, the complete downhole picture has been interrupted by an igneous sill complex between 58 and 105.5 meters sub-bottom, destroying tetrapyrrole pigments in the lower sections (see also site reports, this volume).

Though not given as a figure, pigment-yield trends for the combination of Sites $10 \mathrm{G}$ and 481/481A indicate the initial rapid oxidative loss of tetrapyrrole pigment, mentioned above (cf. Fig. 1A), the fluctuation of initialorganic-input quality (i.e., compare to Site 479; Fig. $1 \mathrm{C})$, and the interruption of the overall diagenetic trend by igneous intrusions (i.e., compare to Site 477 ; see site reports).

Because of high sedimentation rates at these active margin sites, the diagenesis of chlorophyll has been compressed on a temporal basis. Thus, the foregoing discussion covers rather short-term (i.e., Quaternary), high-temperature diagenesis $\left(\sim 95-161^{\circ} \mathrm{C} / \mathrm{km}\right.$; see site reports, this volume). Previously, the combined profile obtained from the passive-margin sites studied from the Japan Trench transect (DSDP Legs 56 and 57; Baker and Louda, 1980; Louda et al., 1980) show that similar phenomena occur during long-term (i.e., Miocene) lowtemperature diagenesis $\left(\sim 10^{\circ} \mathrm{C} / \mathrm{km}\right.$; see Vol. 56-57, Site Summaries, Scientific Party, 1980). Temporal suppression of the break-point in pigment loss (i.e., stabilization) was attributed to both low sedimentation rates and a low thermal gradient (cf. Baker and Louda, 1980a; Louda et al., 1980), as compared to the Gulf of California sediment strata under discussion here.

\section{Individual Tetrapyrroles}

Underlying the trends in the relative loss or survival of total tetrapyrrole assemblages, as discussed above, is the presence or absence of specific chlorophyll derivatives which form via alternate diagenetic pathways. These compounds thus may serve also as markers of paleoenvironment, geothermal history, and organic sources. The mole-percent composition of tetrapyrrolepigment assemblages isolated from Leg 64 and Leg 64 site survey core samples is presented as Table 3 . Because of the large number of samples investigated, only Sample 10G-10 from the site-survey sample suite was completely analyzed for all three pigment classes (tetrapyrrole, tetraterpenoid, and perylene). Further analyses of the remainder of samples from Sites $10 \mathrm{G}$ and $18 \mathrm{G}$ are planned.

During analysis, the first chromatographic separation was based upon three polarity classes and was performed over microcrystalline cellulose (see materials and methods section, this chapter). We report as part of Table 3 the percent non-polar (i.e., phytylated and totally decarboxylated) phorbides and chlorins and its com- plement, the polar (i.e., carboxylated) fraction. A priori, we expected to observe initial increases in the polar fraction at the expense of the non-polar (phytyl-ester) fraction, followed by an increase in the non-polar fraction because of decarboxylation of phorbide and chlorin free acids. This pattern did not emerge directly, and these relationships are still under study.

During rechromatography (silica l.p.l.c.) of the nonpolar fraction obtained from cellulose chromatography two, and in the shallowest sediments (10G-10, 479-3-2, 481-8-2), three major forms of pheophytin-a were isolated. Referring to Table 3, the form we have designated as pheophythin-a 2 was found to co-elute with authentic pheophytin-a (I). The electronic spectral characteristics of the non-metallotetrapyrrole pigments isolated from Leg 64 core samples are presented as Table 4. The electronic spectra of all three forms of pheophytin-a (i.e., 1, 2 , and 3 ) were found to be exceedingly similar, not only in the position of absorption maxima, but also in the absorption ratios of Soret to band I and band I to band IV. Until further studies are performed, the subtle differences in the electronic spectra of these pigments cannot be considered diagnostic (see Appendix B).

Partially allomerized (i.e., the 10-oxy-analog: III) authentic pheophytin-a was submitted to silica 1.p.l.c. and allowed classification of the isolate designated pheophytin-a3 as the allomer. The least-polar of these three forms of pheophytin-a (i.e., 1) was tentatively identified as pyro-pheophytin-a (i.e., having lost the C-10 carbomethoxy moiety; II). It should be pointed out that each of the pheophytins-a isolated may be composed of a mixture of the respective dihydrophytylpheophorbide-a plus the true phytyl ester form; that is, prior studies have shown the existence of pheophytin-a in which the isolated double bond of the phytyl ester had been reduced (see Baker, 1970; Baker and Smith, 1973).

Sediments from the oxygen-minimum site (479) yielded an array of phorbides thought by the authors to represent a diagenetic continuum between pheophytin-a (I) and free-base desoxophylloerythroetioporphyrin (DPEP: $\mathrm{XV})$; that is, the sequential stages in the defunctionalization of pheophytin-a (I).

Referring to Tables 3 and 4, the compound designated Phorbide-658.5 is believed to be 7-ethyl-7-desproprio-meso-(alt. 2-methyl-2-desvinyl)-pyropheophorbide-a (X) or a very similar analog. The electronic spectrum of Phorbide-658.5 (Table 4; Fig. 2A) matches that reported for the 9-keto-mesopheophorbide-a series (Fischer and Stern, 1940). Upon treatment of Phorbide-658.5 with $\mathrm{NaBH}_{4}$ in $20 \%$ ethanolic ethyl ether, a reduction product with Soret absorption at $392.0 \mathrm{~nm}$ and visible bands at 498.0 (IV), 588(II), and 642.0 (I) $\mathrm{nm}$ was obtained. The position of absorption maxima, visible band order (i.e., I > IV > II), and the lack of fine structure between 500 and $575 \mathrm{~nm}$ all match the electronic spectrum obtained for desoxomesopyropheophorbide-a (XII: see Fig. 2A; cf. Appendix B, this chapter; Baker and Louda, 1980a). Chromatographically, Phorbide-658.5 eluted prior to pheophytins-a1 and -a2, prior to known isocryptoxanthin (i.e., a carotenol: XXX), and following both 
DPEP and echinenone (i.e., a carotenone: XXVIII). All data indicate that this pigment is a mesopyropheophorbide-a, lacking the carboxyl moiety.

Phorbide-641 (see Tables 3 and 4; Fig. 2B) was tentatively identified as desoxomesopyropheophorbide-a (cf. $\mathrm{X}$ ) and also is most likely the 7-ethyl-7-desproprio form. Tentative identification of Phorbide-641 rests upon the arguments given above during discussion of Phorbide658.5. Removal of the 2 -vinyl group as an auxochrome to the main phorbide chromophore may occur via reduction to 2-ethyl, oxidation to 2-formyl, 2-acetyl, 2methyl, or 2-H (i.e, desvinyl). The oxo-derivatives (i.e., formyl, acetyl) would, of course, require reduction in order to yield a meso-phorbide-type electronic spectrum. This point is considered below.

Phorbide- 686.5 at first was designated by the authors as a chlorin or purpurin, because of the unusual electronic spectrum obtained (Table 4; Fig. 2C); however, upon borohydride treatment, the reduction product yielded an electronic spectrum identical to the 9-oxydeoxo-pheophorbides-a we reported previously (Baker and Louda, 1980a; cf. Appendix B, herein). Further, the visible spectrum reported for a variety of 2-desvinyl-2acetyl-9-keto-phorbides (Fischer and Stern, 1940) matches that of the Phorbide- 686.5 isolate. The bifurcated Soret reported here (Table 4; Fig. 2C) is also reminiscent of, but not identical to, that reported for pheophytin-d (Holt, 1966; Goedheer, 1966; Smith and Benitz, 1955), the 2-desvinyl-2-formyl analog of pheophytin-a. As discussed later, we feel that Phorbide-686.5 is an oxidation product of pheophytin-a (I) formed during or just following sedimentation (i.e., pre- or syn-depositional), and that it is not a pheophytin-d derivative.

Phorbide 646.8, based upon electronic spectral and chromatographic characteristics, appears to be a 9-oxy9-deoxo-2-vinyl-phorbide of the chlorophyll-a series. Proper knowns are not available at this time, but elution during l.p.l.c. further indicates the lack of the 10-carbomethoxy group. Whether this compound exists as the 7-phytyl (alt. dihydrophytyl) ester or the 7-ethyl-7-desproprio-analogs awaits mass spectrometric verification.

The above dihydroporphyrins have all been tentatively identified as phorbides in varying stages of defunctionalization, beginning with pheophytin-a, and eventually giving rise to DPEP via aromatization of desoxomesopyropheophorbide-a (DMOPP-a: XII). Verification of structure for a few, or all, of the compounds mentioned above should allow substantiation of the diagenesis of chlorophyll as originally proposed (see Treibs, 1936; cf. Baker and Palmer, 1978).

As we proposed previously (cf. Baker and Louda, 1980a; Louda et al., 1980), a major pathway in the early diagenesis of tetrapyrrole pigments appears to involve oxidative cleavage of the isocyclic ring forming purpurin-18 (XIX) and chlorins of the $-\mathrm{e}_{6}$ (XVII) or $-\mathrm{p}_{6}$ (XX) type. The total extract of Sample 481-2-2, 125-150 cm, an olive-gray diatomaceous ooze from 7.6 meters subbottom in the Guaymas Basin, yielded an electronic spectrum (i.e., total pigments) with a large and pronounced shoulder at about 692 to $700 \mathrm{~nm}$. This sample was not analyzed for all pigment classes, rather for only one or two of the main chlorins in order to optimize purification and yield. Following the initial chromatography over cellulose, the long-wavelength-absorbing species were found concentrated in the monocarboxylic acid fraction (i.e., cellulose fraction 2 , see materials and methods section), while the polar fraction (i.e., cellulose fraction 3), containing di- and tri-carboxylic acid chlorins yielded an electronic spectrum very reminiscent of chlorin- $\mathrm{p}_{6}$ (XX: cf. Appendices A and B).

Methyl esterification of these fractions with diazomethane (according to Baker and Louda, 1980) was performed, and each fraction was rechromatographed over silica gel. The compound tentatively identified as purpurin-18 (XIX: Fig. 2D), as the methyl ester, eluted with $15 \%$ acetone in petroleum ether, as did the tri-methyl ester of chlorin- $\mathrm{p}_{6}$ (XX: Fig. 2D) during a separate chromatography. The formation and identification of these compounds is described elsewhere (Baker and Louda, 1980a; Louda et al., 1980) and discussed in the following section on diagenesis.

Chlorin-636 (Tables 3 and 4) is an enigma at present. This pigment was isolated in trace amounts and, except for Sample 481-8-2 (see Table 3), always from those sediments containing free-base porphyrins (DPEP). Chlorin-like pigments exhibiting band I absorption at $636 \mathrm{~nm}$ in ethyl ether and accompanying free-base DPEP (XV) have previously been isolated from sediments recovered from the deep-sea terrace off Japan (DSDP/Site 438; Baker and Louda, 1980) and the outer continental borderlands of Baja California (DSDP Site 471; Louda and Baker, in press). In both of these reports, we draw a parallel between the existence of "chlorin-636" and free-base DPEP (XV) and suggest that chlorin-636 may be a secondary chlorin (cf. Blummer and Omenn, 1961) derived from DPEP (XV) by oxidation during sediment reworking. This still appears to be the best explanation, even though it is perplexing that the three forms of chlorin-636 (i.e., Sites 438 and 471 , mentioned above, and those reported in Table 3 , this report) yield electronic spectra which do not exactly resemble each other.

The designation "chlorin-660-complex," given in Table 3, refers to isolates which yield chlorin-like electronic spectra (e.g., Soret $=405 \mathrm{~nm}$, band II $=605 \mathrm{~nm}$, and band $\mathrm{I}=660 \mathrm{~nm}$, in ethyl ether), but which cannot be purified further by the chromatographic or acidextraction methods used herein (see materials and methods section). Electronic spectra of these isolates always exhibit a high background in the spectral range of 325 to about $600 \mathrm{~nm}$. The resultant spectra resemble those reported for humic acids (see, e.g., Brassel et al., 1980 ), yet with somewhat more detail. Chlorin-660complex is routinely isolated in the fastest-migrating fraction during gel-permeation chromatography (GPC) through Sephadex-LH-20R (i.e., at or near the exclusion limit of $\sim 4000$ daltons), thus suggesting a macromolecular complex. Much further study on this complex (compound?) is required. In a previous report (Louda and Baker, 1981) we mentioned that vanadyl porphyrins appear to arise via a route quite different from nickel porphyrins (cf. Baker, Palmer, Huang, et al., 1978; 
Table 3. Mole-percent composition of tetrapyrroles isolated from DSDP Leg 64 sediment samples.

\begin{tabular}{|c|c|c|c|c|c|c|c|c|c|c|}
\hline \multirow[b]{2}{*}{$\begin{array}{c}\text { Sample }{ }^{\mathrm{a}} \\
\text { (interval in cm) }\end{array}$} & \multicolumn{10}{|c|}{ Mole Percent, Based on Total Tetrapyrrole Assemblages ${ }^{a, b}$} \\
\hline & $\begin{array}{l}\text { Pheophytin-al } \\
\text { (pyro- } \\
\text { pheophytin-a) }\end{array}$ & $\begin{array}{l}\text { Pheophytin-a2 } \\
\text { ("true"" } \\
\text { pheophytin-a) }\end{array}$ & $\begin{array}{l}\text { Pheophytin-a3 } \\
\text { (pheophytin-a } \\
\text { allomer) }\end{array}$ & $\begin{array}{l}\text { "Phorbide". } \\
663\end{array}$ & $\begin{array}{c}\text { "Phorbide". } \\
658.5\end{array}$ & $\begin{array}{l}\text { "Phorbide". } \\
646.8\end{array}$ & $\begin{array}{l}\text { "Phorbide"- } \\
641\end{array}$ & $\begin{array}{c}\text { "Chlorin"- } \\
651\end{array}$ & $\begin{array}{l}\text { "Chlorin"- } \\
636\end{array}$ & $\begin{array}{l}\text { Purpurin- } \\
\text { 18-like }^{\mathrm{d}}\end{array}$ \\
\hline $\begin{array}{l}\text { 10G-3, 3.9-5.9 } \\
10 \mathrm{G}-5,7.9-9.8 \\
10 \mathrm{G}-7,11.8-13.8 \\
10 \mathrm{G}-10,17.7-19.7\end{array}$ & 9.4 & 15.4 & 11.3 & & & & & & & 0.8 \\
\hline $\begin{array}{l}\text { 18G-I, 1-10 } \\
\text { 18G-V, } 160-170\end{array}$ & & & & & & & & & & \\
\hline $\begin{array}{l}474-2-3,120-150 \\
474-17-6,100-125 \\
474 \mathrm{~A}-7-2,110-140 \\
474-28-2,120-150 \\
474 \mathrm{~A}-32-2,120-150 \\
474 \mathrm{~A}-41-3,120-150\end{array}$ & 5.0 & 20.0 & & & 3.0 & $\begin{array}{l}1.0 \\
1.0\end{array}$ & 2.9 & & 2.0 & 0.8 \\
\hline $\begin{array}{l}477-5-1,120-140 \\
477-7-1,132-142 \\
477-16-5,58-88 \\
477-20-1,115-135\end{array}$ & 2.1 & 6.9 & & 2.4 & $<0.1$ & & 23.3 & & $\begin{array}{r}<0.1 \\
1.1\end{array}$ & 2.0 \\
\hline $\begin{array}{l}479-3-2,110-130 \\
479-5-3,125-150 \\
479-7-5,110-140\end{array}$ & $\begin{array}{l}2.8 \\
3.0 \\
2.5\end{array}$ & $\begin{array}{l}11.3 \\
11.5 \\
11.5\end{array}$ & 6.8 & 0.9 & & & $<0.1$ & & & 0.7 \\
\hline $479-9-2,115-140$ & 1.3 & 6.0 & & & 1.3 & & 0.3 & & 0.1 & \\
\hline $479-13-1,110-140$ & 0.2 & & & 3.0 & 1.0 & 0.8 & 0.1 & & $<0.1$ & \\
\hline $479-15-5,110-140$ & & & & & 1.5 & 1.0 & 1.0 & & 1.0 & \\
\hline $479-17-5,120-150$ & & & & & 2.6 & 0.8 & & & & \\
\hline $479-19-5,115-140$ & & & & & 2.0 & 1.0 & 0.2 & & & \\
\hline $479-22-5,110-140$ & & & & & 1.1 & 2.0 & & 1.3 & & \\
\hline $479-27-4,120-150$ & & & & & 1.3 & 0.1 & & & $<0.1$ & \\
\hline $479-29-5,120-150$ & & & & & & 1.6 & 1.1 & & & \\
\hline $479-34-5,110-140$ & & & & & & $<0.1$ & 0.5 & & 1.2 & \\
\hline $479-37-5,130-140$ & & & & & & & 1.7 & & & \\
\hline $479-39-4,110-140$ & & & & & & & 1.9 & & & \\
\hline $479-43-1,120-140$ & & & & & & & 4.7 & & & \\
\hline $479-47-4,110-140$ & & & & & & & 2.5 & & & \\
\hline $481-2-2,125-150$ & & & & & & & & & & ++ \\
\hline $481-8-2,110-140$ & 3.9 & 2.4 & 6.8 & & & & & & $<0.1$ & 1.7 \\
\hline $481-11-1,125-150$ & & & & & & & & & & \\
\hline $481 \mathrm{~A}-8-2,110-150$ & & & & & & $\sim 0.3$ & & & & \\
\hline $481 \mathrm{~A}-10-2,110-150$ & & & & & & & & & & \\
\hline $481 \mathrm{~A}-13-6,0-14$ & & & & & & & & & & \\
\hline $481 \mathrm{~A}-22-4,122-150$ & & & & & & & 6.1 & & & \\
\hline $481 \mathrm{~A}-24-5,110-140$ & & & & & & & & & & \\
\hline $481 \mathrm{~A}-26-5,120-150$ & & & & & & & & & & \\
\hline $481 \mathrm{~A}-30-5,110-140$ & & & & & & & & & & \\
\hline
\end{tabular}

Mackenzie et al., 1980); that is, vanadyl porphyrins appear to be released from a complexed or non-extractable portion of the organic matrix only after sufficient thermal stress has been imposed (e.g., $70^{\circ} \mathrm{C}+$ in Miocene strata; cf. Louda and Baker, 1981). Perhaps the "chlorin-660-complex" reported herein is the precursor of such a tetrapyrrole containing polycondensed macromolecule. Large-molecular-weight porphyrin complexes have been reported by others (Blumer and Rudrum, 1970).

Free-base desoxophylloerythroetioporphyrin (XV: DPEP) was found to have been formed from phorbide precursors in two main situations during the present investigation.

In the previous report (Louda and Baker, 1981), it was pointed out that the reactions of aromatization (i.e., generation of free-base porphyrins from phorbides) and chelation (i.e., formation of metalloporphyrins, viz. nickel, from free-base porphyrins) usually overlap in the geologic record. Thus, during the examination of the aromatization reaction one must consider only the chromophores involved-namely dihydroporphyrin and porphyrin. Figure 3 is the plot of percent dihydroporphyrins (i.e., free-base phorbides and chlorins) and the complement, percent porphyrins (i.e., free-base and metallo-species versus sub-bottom depth and present in situ temperatures obtained for sediments from the oxygenminimum site (479). The region of most active aromatization was found to occur within sediments presently at about 25 to $38^{\circ} \mathrm{C}$ (see Fig. 3). Previously, aromatization was found to have only barely begun at about $11^{\circ} \mathrm{C}$ in Miocene sediments from the Japan Trench inner wall (Baker and Louda, 1980a) and to have been most active in Pliocene and Miocene sediments from the San Miguel Gap, California borderlands, throughout the temperature range of about 15 to $38^{\circ} \mathrm{C}$ (Louda and Baker, 1981). Thus, with the data herein, an upper temperature limit of $40^{\circ} \mathrm{C}$ for the existence of phorbides and chlorins (i.e., before aromatization is completed) in marine sediments is revealed. The initiation of the aromatization re- 
Table 3. (Continued).

\begin{tabular}{|c|c|c|c|c|c|c|c|c|c|c|c|}
\hline \multirow[b]{2}{*}{$\begin{array}{l}\text { Chlorin- } \\
\text { P6-like }\end{array}$} & \multirow[b]{2}{*}{$\begin{array}{l}\text { Phorbide- } \\
686.5\end{array}$} & \multicolumn{5}{|c|}{ Mole Percent, Based on Total Tetrapyrrole Assemblages ${ }^{a, b}$} & \multicolumn{2}{|c|}{$\begin{array}{c}\text { Mole Percent of } \\
\text { Dihydroporphyrins }{ }^{\mathrm{c}}\end{array}$} & \multicolumn{3}{|c|}{ Mole Percent of Total Tetrapyrroles } \\
\hline & & $\begin{array}{l}\text { Chlorin- } \\
678\end{array}$ & $\begin{array}{l}\text { Chlorin-660 } \\
\text { "Complex" }\end{array}$ & $\begin{array}{l}\text { Free-base } \\
\text { Porphyrins } \\
\text { (7-ethyl- } \\
\text { 7-desproprio) }\end{array}$ & $\begin{array}{l}\text { Nickel } \\
\text { Phylloerythrin } \\
\text { (7-ethyl- } \\
\text { 7-desproprio) }\end{array}$ & $\begin{array}{l}\text { Metallo- } \\
\text { porphyrins }\end{array}$ & $\begin{array}{l}\text { Non-polar } \\
\text { Phorbides } \\
\text { and Chlorins }\end{array}$ & $\begin{array}{c}\text { Polar } \\
\text { Phorbides } \\
\text { and Chlorins }\end{array}$ & $\begin{array}{l}\text { Phorbides } \\
\text { and Chlorins }\end{array}$ & Free-Base & $\begin{array}{c}\text { Ni Phyllo- } \\
\text { erythrin and } \\
\text { Metalloporphyrins }\end{array}$ \\
\hline & & & & & & & 15.5 & 84.5 & 100 & & \\
\hline & & & & & & & 26.2 & 63.8 & 100 & & \\
\hline & & & & & & & 9.7 & 90.3 & 100 & & \\
\hline & & & & & & & 36.9 & 63.1 & 100 & & \\
\hline & & & & & & & $\begin{array}{l}29.5 \\
16.2\end{array}$ & $\begin{array}{l}70.5 \\
83.8\end{array}$ & $\begin{array}{l}100 \\
100\end{array}$ & & \\
\hline & & 38.8 & & 2.4 & & 0.3 & 71.8 & 28.2 & 97.3 & 2.4 & 0.3 \\
\hline & & 2.7 & 73.9 & & 13.2 & 9.3 & na & na & 77.5 & & 22.5 \\
\hline & & & 25.0 & & 38.0 & 36.0 & na & na & 26.0 & & 74.0 \\
\hline & & & & & 21.5 & 78.5 & & & & & 100 \\
\hline & & & & & 12.2 & 87.8 & & & & & 100 \\
\hline & & & & & 52.0 & 49.0 & & & & & 100 \\
\hline & 3.4 & & & $<0.1$ & 1.0 & $<0.1$ & 17.9 & 82.1 & 99.0 & $<0.1$ & 1.0 \\
\hline & & & & 75.6 & & & na & na & 24.4 & 75.6 & \\
\hline & & & & & & & 21.6 & 78.4 & 100 & & \\
\hline & 11.9 & & & & & & 26.3 & 73.7 & 100 & & \\
\hline & & & & & & $<0.1$ & 14.8 & 85.2 & $>99.9$ & & $<0.1$ \\
\hline & & & & 0.5 & & 0.2 & 9.6 & 90.4 & 99.7 & 0.5 & 0.2 \\
\hline & & & 0.6 & 2.6 & 0.3 & & 5.3 & 94.7 & 97.1 & 2.6 & 0.3 \\
\hline & & 0.4 & & 1.1 & 0.2 & & 6.9 & 93.1 & 98.7 & 1.1 & 0.2 \\
\hline & & & & 0.5 & 0.6 & $<0.1$ & 4.5 & 95.5 & 98.7 & 0.5 & $<0.7$ \\
\hline & & & 87.0 & 1.4 & 5.8 & 2.7 & 5.3 & 94.7 & 90.1 & 1.4 & 8.5 \\
\hline & & & 81.3 & 9.7 & 3.1 & 1.5 & 6.7 & 93.3 & 85.7 & 9.7 & 4.6 \\
\hline & & & 56.5 & 7.8 & 8.4 & 4.9 & na & na & 78.9 & 7.8 & 13.3 \\
\hline & & & 68.8 & 13.1 & 7.4 & 8.0 & na & na & 71.5 & 13.1 & 15.4 \\
\hline & & & 38.2 & 28.8 & 12.5 & 17.8 & na & na & 40.9 & 28.8 & 30.3 \\
\hline & & & 2.4 & 28.8 & 19.2 & 47.9 & na & na & 4.1 & 28.8 & 67.1 \\
\hline & & & & 37.0 & 24.0 & 37.1 & na & na & 1.9 & 37.0 & 61.1 \\
\hline & & & & 56.1 & 9.9 & 29.3 & na & na & 4.7 & 56.1 & 39.2 \\
\hline & & & & 45.7 & 12.0 & 39.8 & na & na & 2.5 & 45.7 & 51.8 \\
\hline \multirow{9}{*}{$\begin{array}{l}++ \\
3.1\end{array}$} & & & & & & & na & na & 100 & & \\
\hline & & & & & & $<0.1$ & 18.0 & 82.0 & $>99.9$ & & $<0.1$ \\
\hline & & & & & & & 21.5 & 78.5 & 100 & & \\
\hline & & & & & 59.0 & 40.7 & na & na & 0.3 & & 99.7 \\
\hline & & & & & 50.0 & 50.0 & na & na & & & 100 \\
\hline & & & & & 39.9 & 54.0 & na & na & 6.1 & & 93.9 \\
\hline & & & & & 51.2 & 48.8 & na & na & & & 100 \\
\hline & & & & & 78.3 & 21.7 & na & na & & & 100 \\
\hline & & & & & 55.3 & 44.7 & na & na & & & 100 \\
\hline
\end{tabular}

action rests primarily on the time-temperature relationships of thermal reactions. That is, in sediments which are deposited slowly and into regions of low heat flow, aromatization requires much longer geologic time for initiation (e.g., $11-15^{\circ} \mathrm{C}$, Miocene; cf., Louda and Baker, 1981). This contrasts with the rapidly deposited sediments and high thermal gradients of the Gulf of California in which much shorter times but higher temperatures were found to be required for the aromatization of phorbides (e.g., $25^{\circ} \mathrm{C}$, Quaternary).

Section 477-7-1, an olive-gray, nannofossil-bearing, diatomaceous ooze of late Pleistocene age, recovered 8.2 meters above a $\mathbf{4 7 . 5}$ meter thick igneous sill, was found to contain large quantities of free-base DPEP. The formation of such large quantities (i.e., $7.38 \mu \mathrm{g}$ free-base DPEP per gram sediment, dry wt.; cf. Tables 2 and 3 ) of free-base porphyrin is attributed to geologically short-term elevated temperature (e.g., $50-100^{\circ} \mathrm{C}$ ) processes caused by a very high thermal gradient at this site and not by the implacement of the sill, which occurred prior to the deposition of this stratum (see site summaries, this volume). That this diagenesis did not result in the formation of metalloporphyrins is somewhat perplexing. That is, compression of the time scale of aromatization to this degree assuredly must have surpassed also the activation energy required for chelation. Specifically, we have already shown herein and previously (Louda and Baker, 1981) that these reactions overlap somewhat in their respective time-temperature requirements. However, the fact that chelation has not occurred reinforces the observation that the geochemistry of chlorophyll obeys the time-temperature interdependence of organic reactions (cf. Baker and Palmer, 1978; Louda and Baker, 1981).

Nickel phylloerthyrin (cf. XVI: i.e., 9-oxo-NiDPEP) as the decarboxylated form was found to be prevalent in the deeper sections of Sites 474, 479, and 481 (see Table 3). Nickel phylloerythrin (XVI: NiPE) yielded an electronic spectrum with Soret absorption at $404.5 \mathrm{~nm}$ and an alpha band at $589.5 \mathrm{~nm}$ in ethyl ether. The lack of fine structure between about 450 and $570 \mathrm{~nm}$, position of absorption maxima, and overall spectral shape (i.e., quality) match that reported for synthetic NiPE (Hodgson and Baker, 1967) and for other geologic NiPE isolates (cf. Louda and Baker, 1981). The presence of the 9-keto function in this pigment was verified by treatment with sodium borohydride and yielded a product exhibiting Soret absorption at $393 \mathrm{~nm}$ and visible bands 
Table 4. Electronic absorption spectra and spectral characteristics of non-metallotetrapyrrole pigments isolated from DSDP Leg 64 core samples.

\begin{tabular}{|c|c|c|c|c|c|c|c|c|c|c|c|}
\hline \multirow{3}{*}{$\begin{array}{l}\text { Pigment Class: } \\
\text { Compound/Designation }{ }^{a} \\
\text { (tentative identification) }\end{array}$} & \multicolumn{8}{|c|}{$\begin{array}{l}\text { Absorption Maxima } \\
(\mathrm{nm})\end{array}$} & \multirow{3}{*}{$\begin{array}{l}\text { Visible Band Order } \\
\text { (decreasing extinction) }\end{array}$} & \multirow{2}{*}{\multicolumn{2}{|c|}{$\begin{array}{c}\text { Band } \\
\text { Ratios }^{c}\end{array}$}} \\
\hline & \multirow{2}{*}{$\begin{array}{c}\text { Soret } \\
\text { Band(s) }\end{array}$} & \multicolumn{7}{|c|}{ Visible Bands } & & & \\
\hline & & v & IV & III & IIa & II & Ia & I & & $\mathrm{S} / \mathrm{I}$ & I/IV \\
\hline \multicolumn{12}{|l|}{ Phorbides, Chlorins } \\
\hline $\begin{array}{l}\text { Pheophytin-al } \\
\text { (pyro-pheophytin-a) }\end{array}$ & 410.2 & 474 & 504.0 & 535.5 & 561 & 610.0 & - & 667.0 & I,IV,III,II,V,IIa & 1.8 & 5.0 \\
\hline $\begin{array}{l}\text { Pheophytin-a2 } \\
\text { ("true" pheophytin-a) }\end{array}$ & 410.5 & 474 & 504.5 & 534.5 & 561 & 610.0 & - & 666.5 & I,IV,III,II,V,IIa & 1.9 & 5.3 \\
\hline $\begin{array}{l}\text { Pheophytin-a3 (allomer) } \\
\text { (10-oxy-pheophytin-a) }\end{array}$ & 409.5 & 470 & 505.0 & 535.0 & 559 & 610.0 & - & 667.0 & I,IV,III,II,V,IIa & 1.8 & 5.5 \\
\hline $\begin{array}{l}\text { Phorbide-663 } \\
\text { (10-oxy-mesopheophytin-a?) }\end{array}$ & 406.5 & (470) & 503.5 & 534.0 & $(560)$ & 606 & - & 663.0 & I,IV,III,II,V,IIa & 2.8 & 4.8 \\
\hline Phorbide-658.5 & 406.5 & (465) & 498.0 & 532.0 & $(555)$ & 599.5 & (635) & 658.5 & I,IV,III,II,(V),(Ia),(IIa) & 2.8 & 6.7 \\
\hline Phorbide- 646.8 & 393.5 & - & 486 & - & (552.4) & 590 & - & 646.8 & I,IV,II,III & 3.4 & 5.8 \\
\hline Phorbide-641 & 392.0 & - & 498 & $(525-530)$ & - & $586-590$ & - & 641.0 & I,IV,II,III & - & - \\
\hline Chlorin-636 & $358<398.0$ & - & - & (545) & - & 585 & - & 636.0 & I,II,(III) & 7.6 & - \\
\hline Chlorin-686.5 & $357>406$ & - & - & - & $(575-580)$ & 625 & - & 686.5 & I,II,IIa & - & - \\
\hline Chlorin-678 & $354>406$ & - & - & - & $(580-590)$ & 623 & - & 678 & $\mathrm{I}, \mathrm{II}, \mathrm{IIa}$ & - & - \\
\hline Purpurin-18(?) & $(360)<407.5$ & (478) & 506 & 542 & - & (640) & - & 695.5 & I,III,II,IV,V & 3.2 & 7.5 \\
\hline Chlorin-p6(?) & 406.5 & - & 503 & 533 & 565 & 611 & - & 670.5 & I,IV,III,II,IIa & 2.1 & 5.0 \\
\hline \multicolumn{12}{|l|}{ Free-base Porphyrin } \\
\hline DPEP-series & 397.5 & - & 497.5 & 531.0 & - & 566.0 & (589) & 619.5 & IV,I,II,III,Ia,Ila & 28.0 & 0.47 \\
\hline
\end{tabular}

a Pigment designation: dihydroporphyrins classified as phorbide or chlorin (i.e., isocyclic-ring present or absent, respectively), as well as tentative identification, on the basis of electronic absorption spectra, liquid chromatographic behavior, and comparison to various known pigments (see text; cf. Baker and Louda, 1980). Numerical designation (e.g., Chlorin-636) refers to the position in nanometers, of the band I absorption maximum recorded in ethyl ether solvent.

b Absorption spectra recorded in ethyl ether and calibrated versus a holmium oxide standard.

${ }^{c}$ Ratios of absorption maxima determined by correction to background (i.e., absorption above the best-fit curve drawn through absorption minima).

at 515 and $552 \mathrm{~nm}$. In the previous report, nickel desoxophylloerythrin free-acids were found to coexist with the decarboxylated analogs in sediments from the Baja California borderlands (DSDP Site 471). Further, sediments from the San Miguel Gap (DSDP Site 467) were found to contain free-base porphyrins, both as the freeacid and decarboxylated forms (DPE and DPEP; cf. $\mathrm{XVI}, \mathrm{XV}$ ), whereas metalloporphyrin acids were essentially lacking (Louda and Baker, 1981). Thus, we now see that the order of decarboxylation, loss of the 9-keto moiety, aromatization, and chelation is variable. However, both decarboxylation and deketonization generally do occur prior to aromatization and chelation. Therefore, by inference, one must assume that much, but not all, of tetrapyrrole decarboxylation is through low-temperature processes, which may perhaps include microbial activities.

Metalloporphyrins were isolated from the majority of the more deeply buried (e.g., $d>50 \mathrm{~m}$ ) sediments at all sites investigated, except for Site 477 (see Table 3). In the case of Site 477, sediments recovered beneath the igneous sill (58-105.5 m sub-bottom) were determined to be void of recognizable pigments of all classes studied (see Table 2). This is in line with the total pyrolysis of organic matter for these sediments, as reported elsewhere (see site reports, this volume).

According to chromatographic mobility and electronic spectral data (Table 5), the majority of the metalloporphyrins appear to be mixtures of $\mathrm{Cu}$ and $\mathrm{Ni}$ etioporphyrins and the NiDPEP-series. Deconvolution of these complex mixtures is forthcoming as mass spectrometric analyses proceed, and will be published elsewhere. In the previous study we developed and presented the techniques for the separation, recognition, and description of mixtures of allochthonous $\mathrm{Cu}$ and Ni ETIO-porphyrins versus autochthonous (formed in situ) NiDPEPporphyrins (see Louda and Baker, 1981). At present, the metalloporphyrins isolated in near-trace quantities from Sites 474,477 , and 481 appear to be composed mostly of $\mathrm{Cu}$ and Ni ETIO-porphyrins and may represent allochthonous (i.e., performed, terrestrially derived) input (cf. Louda and Baker, 1981; Palmer and Baker, 1978). Conversely, the deeper sections from Site 479 (e.g., $d>200$ m sub-bottom; 479-22-5) appear to be primarily of the NiDPEP type formed via in situ diagenetic processes acting upon autochthonous chlorophyll derivatives.

\section{Tetraterpenoid Pigments}

Carotenoid pigments previously have been isolated from DSDP core samples recovered from the Cariaco Trench (DSDP Site 147; Watts and Maxwell, 1977), the Blake-Bahama Basin (DSDP Hole 391A; Cardoso et al., 1978), the Japan Trench (DSDP Sites 434, 436, and 440; Baker and Louda, 1980a; Brassell et al., 1980; Louda et al., 1980) and the San Miguel Gap, California (DSDP Site 467; Louda and Baker, 1981).

\section{Pigment Yield and Observed Trends}

Carotenoid contents of Leg 64 core samples are given in Table 2.

Carotenoid pigments are known to be extremely susceptible to oxidative destruction (see, e.g., Liaaen-Jen- 

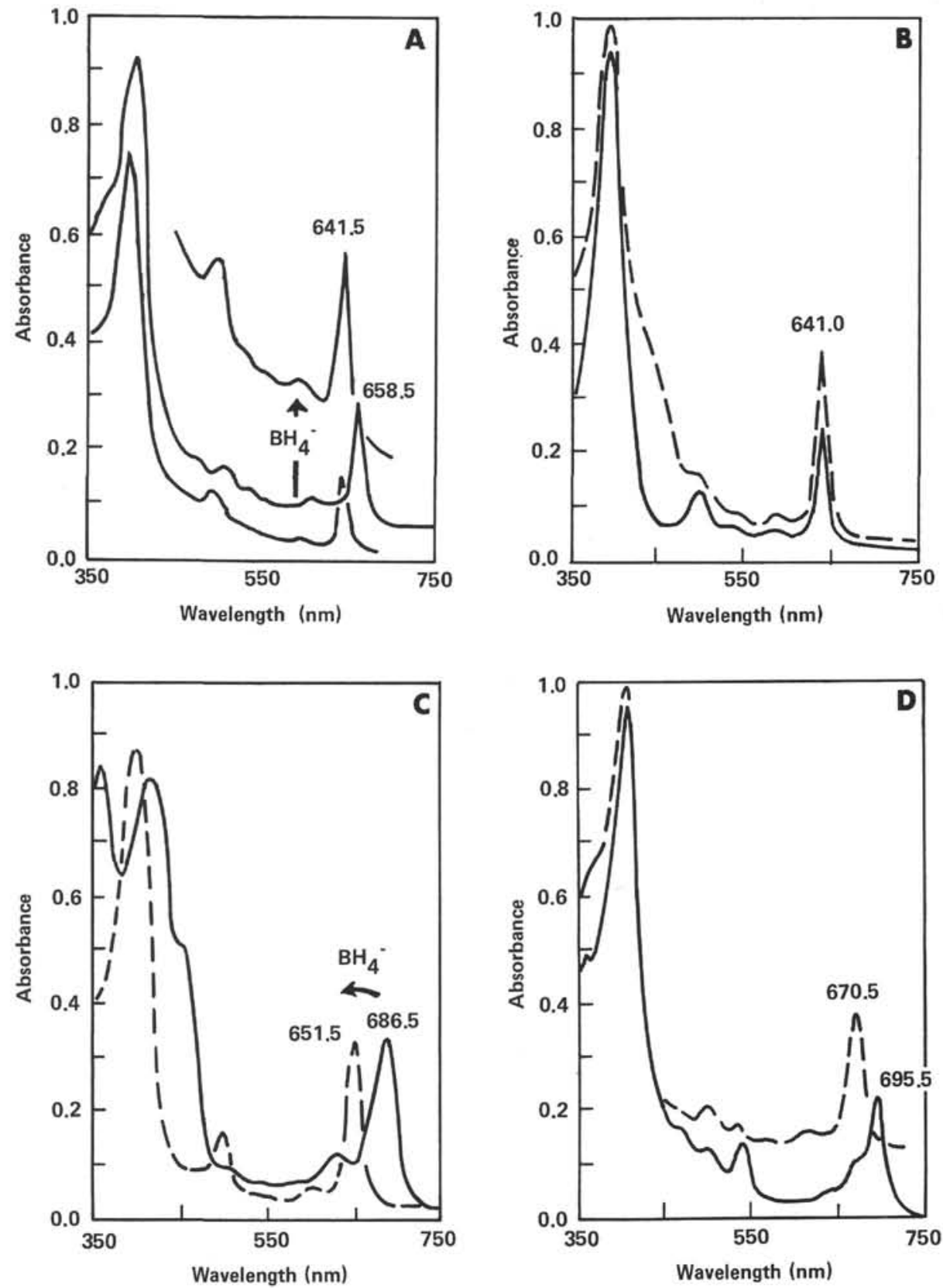

Figure 2. Electronic absorption spectra of selected phorbides, chlorins, and purpurins isolated from DSDP Leg 64 samples. A. Phorbide-658.5, prior to and following borohydride reduction, as indicated. B. Phorbide- 641 (dashed line) compared to authentic desoxomesopyropheophorbide-a (solid line). C. Phorbide-686.5 before (solid line) and after (dashed line) borohydride reduction. D. Partially purified purpurin-18 (solid line) and chlorin-p6 (dashed line) as the methyl esters.

sen, 1971, and references therein) and is thought to occur initially through the formation of epoxides (Simpson et al., 1976), a point to which we shall return later.

Very few studies exist which trace the fate of carotenoids in sediments to beyond the first meter or two of burial. Three samples examined from the Cariaco Trench sediments of DSDP Site 147 yielded 28.5, 2.0, and $0.6 \mathrm{ppm}$ carotenoids (dry wt.) for samples from 3 , 40 , and 75 meters sub-bottom, respectively (Watts and Maxwell, 1977). Sediments recovered from 139, 166, and 212 meters sub-bottom at DSDP Site 440 on the inner wall of the Japan Trench during Leg 57 are reported to contain 275,207 , and $2.8 \mathrm{ng}$ carotenoids per gram of dry sediment, respectively (Brassell et al., 1980). Four equal sections of a 4 -ft $(\sim 1.2 \mathrm{~m})$ core from the Channel Island region off the Southern California coast have been reported as yielding $0.24,0.06,0.05$, and $0.03 \mathrm{mg}$ carotenoids per $100 \mathrm{~g}$ dry weight of sediment, respectively (Fox et al., 1944). In the previous report (Louda and Baker, 1981), we reported that, even though carotenoids were essentially absent from more and less deeply buried strata, sediments from the San Miguel Gap (DSDP Site 467) recovered at 70 and 165 meters yielded 53.0 and $80.9 \mathrm{ng} \beta$-carotene (XII) per gram of dry sedi- 


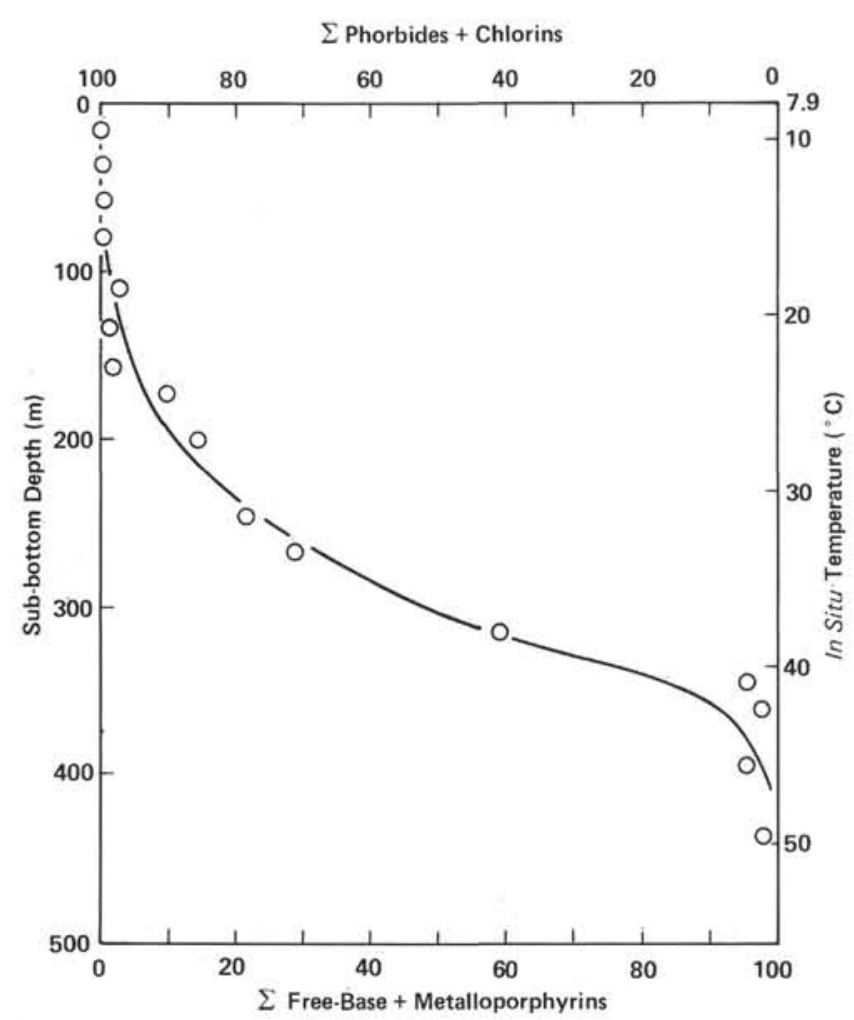

Figure 3. Tetrapyrrole aromatization profile derived from DSDP Site 479 samples (see text).

Table 5. Electronic spectra of metalloporphyrins isolated from DSDP Leg 64 core samples.

\begin{tabular}{|c|c|c|c|c|c|c|}
\hline \multirow{2}{*}{$\begin{array}{c}\text { Sample }{ }^{\mathrm{a}} \\
\text { (interval in cm) }\end{array}$} & \multicolumn{5}{|c|}{$\begin{array}{c}\text { Absorption Maxima }{ }^{\mathrm{b}} \\
(\mathrm{nm})\end{array}$} & \multirow{2}{*}{$\begin{array}{c}\text { Mole Percent } \\
\text { of Total } \\
\text { Metalloporphyrins }{ }^{\mathrm{d}}\end{array}$} \\
\hline & Solvent & Soret & $\beta$-band & $\alpha$-band & $\alpha / \beta^{c}$ & \\
\hline $474-2-3,120-150$ & Ethyl Ether & 393.5 & - & 556.6 & - & 100.0 \\
\hline $474-17-6,100-125$ & Benzene & 398.0 & 523.0 & 558.5 & 1.52 & 100.0 \\
\hline $474 A-7-2,110-140$ & Benzene & 397.5 & 522.5 & 558.0 & 1.44 & 100.0 \\
\hline \multirow[t]{2}{*}{$474 \mathrm{~A}-28-2,120-150$} & Benzene & 398.5 & 525.5 & 561.0 & 1.70 & 46.0 \\
\hline & & 396.0 & 516.5 & 552.0 & 2.33 & 54.0 \\
\hline \multirow[t]{2}{*}{$474 \mathrm{~A}-32-2,120-150$} & Benzene & 398.0 & 523.0 & 560.5 & 1.61 & 36.8 \\
\hline & & 396.0 & 516.0 & 551.5 & 2.07 & 63.2 \\
\hline \multirow[t]{2}{*}{$474 A-41-3,120-150$} & Benzene & 398.0 & 526.0 & 560.5 & 1.72 & 63.7 \\
\hline & & 396.5 & 517.0 & 552.0 & 2.10 & 36.2 \\
\hline $477-5-1,120-140$ & Ethyl Ether & 393.5 & - & 554.0 & - & 100.0 \\
\hline $479-7-5,110-140$ & Benzene & 396.0 & - & 555.0 & - & 100.0 \\
\hline $479-9-2,115-140$ & Benzene & 397.0 & 522.5 & 556.0 & 1.60 & 100.0 \\
\hline $479-19-5,115-140$ & Benzene & 398.0 & 521.5 & 556.0 & 1.80 & 100.0 \\
\hline $479-22-5,110-140$ & Benzene & 398.0 & 522.0 & 556.0 & 1.56 & 100.0 \\
\hline $479-27-4,120-150$ & Benzene & 398.0 & 521.5 & 554.5 & 1.80 & 100.0 \\
\hline $479-29-5,120-150$ & Ethyl Ether & 396.5 & 520.5 & 554.0 & 1.68 & 100.0 \\
\hline \multirow[t]{2}{*}{$479-34-5,110-140$} & Benzene & 398.0 & 524.5 & 561.0 & 1.56 & 21.9 \\
\hline & & 396.5 & 516.6 & 552.5 & 2.13 & 78.1 \\
\hline \multirow[t]{2}{*}{$479-37-5,130-140$} & Benzene & 398.0 & 524.0 & 560.0 & 1.56 & 23.9 \\
\hline & & 395.5 & 515.5 & 552.0 & 2.19 & 76.1 \\
\hline $479-39-4,110-140$ & Benzene & 396.0 & 516.2 & 553.8 & 2.16 & 100.0 \\
\hline $479-43-1,120-140$ & Benzene & 396.5 & 516.5 & 553.5 & 2.09 & 100.0 \\
\hline \multirow{2}{*}{$479-47-4,110-140$} & Benzene & 398.5 & 525.5 & 560.5 & 1.75 & 12.6 \\
\hline & & 396.5 & 516.5 & 553.5 & 2.11 & 87.4 \\
\hline $481-8-2,110-140$ & Benzene & 397.5 & 520 & 555 & 1.5 & 100.0 \\
\hline \multirow[t]{2}{*}{$481 \mathrm{~A}-10-2,110-150$} & Benzene & 398.0 & 526.0 & 561.0 & 1.64 & 57.9 \\
\hline & & 396.5 & 516.5 & 552.5 & 2.20 & 42.1 \\
\hline \multirow[t]{2}{*}{$481 \mathrm{~A}-22-4,122-150$} & Benzene & 398.5 & 524.5 & 560.5 & 1.64 & 56.2 \\
\hline & & 397.0 & 517.0 & 552.5 & 2.25 & 43.8 \\
\hline $481 \mathrm{~A}-24-5,110-140$ & Benzene & 398.0 & 523.0 & 559.0 & 1.79 & 100.0 \\
\hline $481 \mathrm{~A}-26-5,120-150$ & Benzene & 398.0 & 524.5 & 560.0 & 1.67 & 100.0 \\
\hline $481 \mathrm{~A}-30-5,110-140$ & Benzene & 397.5 & 520.0 & 555.0 & 1.66 & 100.0 \\
\hline
\end{tabular}

${ }^{a}$ Refer to Table 2 for sample description, depth, and pigment yields. Refer to Table 3 for mole-

b $\begin{aligned} & \text { percent composition of tetrapyrrole pigments. } \\ & \text { Calibration by reference to holmium oxide standard. }\end{aligned}$

c Calculated by measuring peak height after background correction.

d Determined as the amounts of metalloporphyrin collected from low-pressure liquid chromatographic fractions (see text). ment. This apparent increase was attributed to changes in depositional conditions occurring from the time when these deeper (i.e., $165 \mathrm{~m}$ ) and shallower (i.e., $\leq 70 \mathrm{~m}$ ) sediments were deposited, as the result of sea-level fluctuation in the late Pliocene to Pleistocene.

In the present study, the uppermost eight core samples investigated from Site $\mathbf{4 7 9}$ (see Table 2) provided an excellent example of the destruction of tetraterpenoid pigments with increased depth of burial in marine sediments (see Table 2). Figure 4 is a plot of the carotenoid PYI (i.e., pigment yield index $=\mu \mathrm{g}$ pigment $/ \mathrm{g}$ sediment, dry wt. divided by the percent organic carbon, dry wt.; cf. Table 2, note h; Baker and Louda, 1980) versus depth and present in situ temperatures. Extremely rapid loss of carotenoids, as part of the organic matter, was found for the first 72.0 meters, below which only carotenes survive until all carotenoids have been destroyed, as pigments, by 200.0 meters sub-bottom. The higher yield of carotenoid from Section 479-15-5 (see Table 2), both on an absolute basis and when related to organic carbon content (cf. Fig. 4, data point at 133.6 meters), most likely represents the existence of more-favorable conditions (e.g., expansion of the OMZ anoxicity) during the time when these sediments were deposited.

On the bases of electronic spectra, chromatographic position in comparison to several known compounds

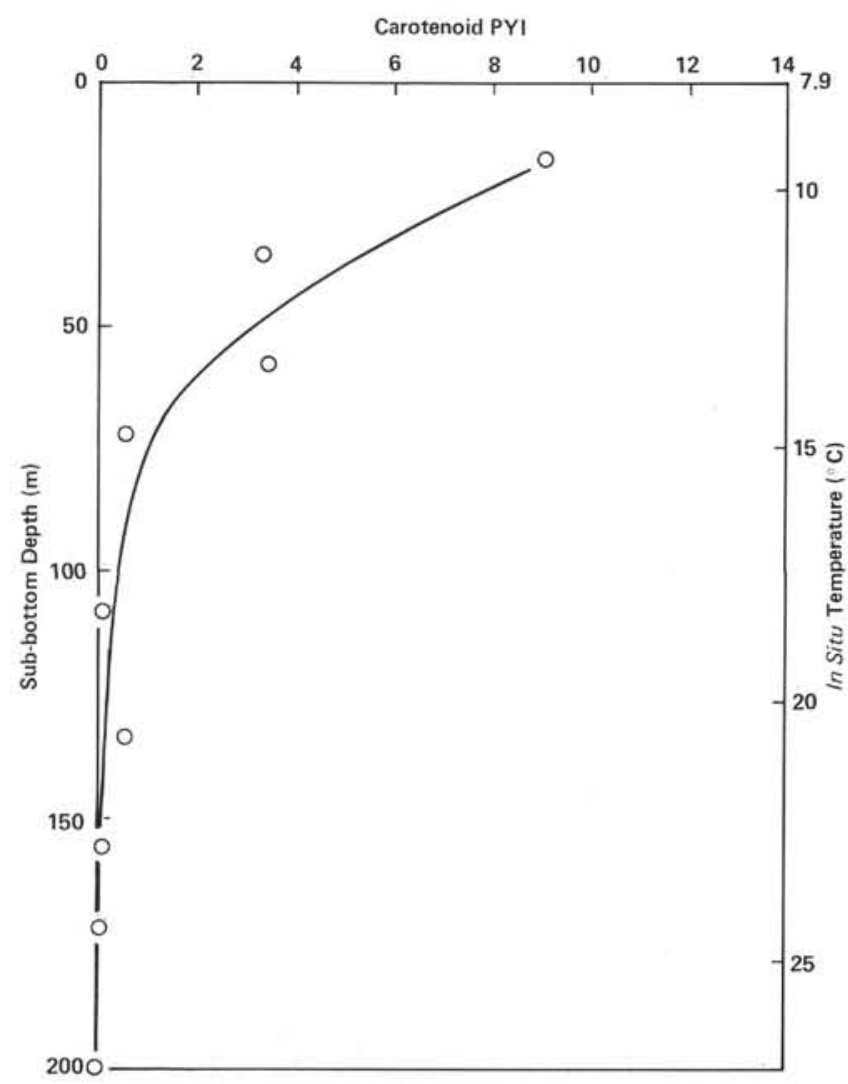

Figure 4. Pigment yield index (defined in Fig. 1 caption) for carotenoid pigments isolated from DSDP Site 479 sediments. 
(see materials and methods section), and reduction with sodium borohydride (i.e., test for conjugated carbonyl groups), carotenoids have been classified as several types. The mole-percent composition of carotenoid mixtures isolated from Leg 64 samples is presented as Table 6 .

During 1.p.l.c. over silica of non-polar fractions (i.e., eluted from cellulose with 0 to $5 \%$ acetone in petroleum ether, cellulose fraction-1; cf. materials and methods section), distinctive patterns of carotenoid composition developed. $\beta$-Carotene (XII), perylene, and metalloporphyrins eluted as separate bands during the initial development with petroleum ether. Resolution of these components was greatly enhanced by using benzene/petroleum ether $(1: 1, \mathrm{~V} / \mathrm{V})$ as the injecting solvent and replacing petroleum ether with $n$-pentane/petroleum ether $(2: 3, \mathrm{~V} / \mathrm{V})$. Re-equilibration of the column, following a $20 \%$ methanol in acetone flush, for periods of 20 to 30 minutes also enhanced separation of the hydrocarbon pigments (cf. Hajibrahim et al., 1978).

Electronic absorption spectra of mixed carotene isolates and purified sub-fractions are given as Table 7. Because the "carotene" fraction isolated via 1.p.l.c. over silica did not always match authentic all-trans- $\beta$-carotene (XII), it was of interest to study this fraction further in order to separate any isomeric forms (e.g., $\alpha$, cis$\beta$, etc.) or less-conjugated $\beta$-carotene derivatives (e.g., di-, tetrahydro- $\beta$-carotenes).

Rechromatography of the total carotenes (i.e., total $\mathrm{C}$ in Table 7) was performed using 1.p.l.c. (see materials and methods section), over activated alumina. In several cases (e.g., 10G-10, 474-2-3, 479-7-5; Table 7), three fractions were obtained. The first $\left(C_{1}\right)$ was almost colorless, being only a very pale yellow, and exhibited main absorption maxima (Band II, $\lambda_{1}$; Table 7) at 438.0 or $444.0 \mathrm{~nm}$ for sections $10 \mathrm{G}-10$ or $474-2-3$, respectively.
The more deeply buried (cf. Table II) Sections 479-7-5 and 479-9-2 yielded even less conjugated $C_{1}$ fractions with their main maxima at 404.5 and $405.0 \mathrm{~nm}$, respectively. These non-polar carotenes are most likely reduction products (cf. Watts and Maxwell, 1977).

Two closely eluting, yet well separated (i.e., $>80 \%$ ), forms of $\beta$-carotene (XII) were also isolated from the total carotenes. All-trans- $\beta$-carotene (XII: $\mathrm{C}_{3}$; Table 7) was found to be the major component in all cases, except for Section 10G-10, the isolate from which was not well enough resolved to comment on. The intermediate eluting carotene $\left(C_{2}\right)$ was tentatively identified as being predominantly central $\left(15,15^{\prime}\right)$-mono-cis- $\beta$-carotene. This designation rests upon the overall resemblance in spectral quality to central-monocis- $\beta$-carotene (cf. Weedon, 1969), the hypsochromic shift of the main maximum $\left(\lambda_{1}\right)$ from 449.5 (i.e., all-trans- $\beta$-carotene) to 443.5 $\mathrm{nm}$, and the presence of a marked "cis-peak" $\left(\lambda_{2}\right)$ at $337.5 \mathrm{~nm}$ in $n$-hexane. The ratios of extinction between the main absorption band $\left(\lambda_{1}\right)$ and the "cis-peak" $\left(\lambda_{2}\right)$-that is $\lambda_{1} / \lambda_{2}$ (see Table 7)-calculated for these isolates were about 3.1 to 7.0 for the cis- $\beta$-carotene isolates, and from 26.0 to 47.0 for the all-trans isolates. Measuring these peak ratios from the published spectra (see Weedon, 1969; Zechmeister, 1960) of central monocis and all-trans- $\beta$-carotene (XII), we obtained $\lambda_{1} / \lambda_{2}$ values of 2.3 to 2.4 and about 50 , respectively.

A group of six to 12 individual carotenoids, depending upon the sample, eluted at the beginning of isocratic elution with $2 \%$ acetone in petroleum ether during l.p.l.c. over silica. This grouping was found to be present in all samples examined from depths of less than 57.6 meters sub-bottom (see Table 6). This cluster appears to consist of two isomers of mutatochrome (XXVII: 5,8 -epoxy-5,8-dihydro- $\beta, \beta$-carotene); two main

Table 6. Mole-percent composition of carotenoid assemblages isolated from DSDP Leg 64 core samples.

\begin{tabular}{|c|c|c|c|c|c|c|c|c|c|}
\hline \multirow[b]{2}{*}{$\begin{array}{c}\text { Sample } \\
\text { (interval in cm) }\end{array}$} & \multicolumn{8}{|c|}{ Mole-Percent Composition ${ }^{b}$} & \multirow{2}{*}{$\begin{array}{c}\text { Ratio of } \\
\text { Carotenes to } \\
\text { Oxy- plus } \\
\text { Oxocarotenoids }\end{array}$} \\
\hline & Carotenes & $\begin{array}{l}\text { Apo- } \\
\text { carotenoids } \mathrm{c}\end{array}$ & $\begin{array}{l}\text { Dehydro- } \\
\text { carotenes }\end{array}$ & Lycopene & Echinenone & $\begin{array}{l}\text { Cantha- } \\
\text { xanthin }\end{array}$ & Carotenols & $\begin{array}{l}\text { Carotene- } \\
\text { diols }\end{array}$ & \\
\hline 10G-10, 17.7-19.7 & 45.5 & & $11.6^{\mathrm{f}}$ & & 11.3 & & 9.0 & 21.6 & 1.38 \\
\hline $\begin{array}{l}474-2-3,120-150 \\
477-5-1,120-140\end{array}$ & $\begin{array}{l}50.1 \\
56.0\end{array}$ & & $12.6^{\mathrm{f}}$ & $14.0^{f}$ & ind. & 18.3 & $\begin{array}{l}4.6 \\
3.9\end{array}$ & $\begin{array}{l}14.3 \\
26.1\end{array}$ & $\begin{array}{l}1.68 \\
2.33\end{array}$ \\
\hline $479-3-2,110-130$ & 54.0 & 1.6 & 5.0 & 1.4 & 2.6 & & 4.4 & 31.0 & 1.63 \\
\hline $479-5-3,125-150$ & 67.1 & ind. & 4.0 & & 0.8 & & 2.0 & 26.0 & 2.47 \\
\hline $479-7-5,110-140$ & 35.9 & 1.4 & 3.1 & & 0.9 & & 1.2 & 57.4 & 0.82 \\
\hline $479-9-2,115-140$ & 92.1 & ind. & & & & & 4.8 & 3.1 & 11.66 \\
\hline $479-13-1,110-140$ & $(100.0)$ & & & & & & ind. & ind. & $<\infty$ \\
\hline $479-15-5,110-140$ & 76.9 & & & & & & 10.7 & 12.4 & 3.33 \\
\hline $479-17-5,120-150$ & 100.0 & & & & & & & & $\infty$ \\
\hline $479-19-5,115-140$ & 100.0 & & & & & & & & $\infty$ \\
\hline $481-8-2,110-140$ & 24.6 & & & & 1.78 & & 13.1 & 43.6 & 0.71 \\
\hline
\end{tabular}

a Refer to Table 1 for sample description.

b Calculated using extinction coefficients and molecular weights as given in Table 1, note f, and in text. Symbols: blank indicates absent; ind. means indicated.

c Apo-carotenoids refers to tentatively identified apo-carotenals and deoxo-apo-carotenals and mutachrome (see text).

d Dehydrocarotenes refers to the sum of individual isolates of dehydro-, didehydro-, and retro-dehydrocarotenes (see text).

e Calculated as the sum of hydrocarbon carotenoids divided by the sum of oxygen-containing carotenoids. This value does not directly equate to hypophasic-epiphasic ratios (i.e., H/E) reported by others (see text).

$\mathrm{f}$ Represents a total fraction including the indicated types for very small isolates or those which were retained for future study.

8 Represents approximately equal amounts of echinenone and an unidentified keto-carotenoid reminiscent of a di- or tetrahydro-echinenone (i.e., $\lambda_{\max }=438 \mathrm{~nm}$ ). 
Table 7. Electronic absorption spectra of "carotenes" and purified carotenes. ${ }^{\text {a }}$

\begin{tabular}{|c|c|c|c|c|c|c|c|c|}
\hline \multirow[b]{2}{*}{$\begin{array}{c}\text { Sample }{ }^{b} \\
\text { (interval in cm) }\end{array}$} & \multirow[b]{2}{*}{ Fraction } & \multirow[b]{2}{*}{$\begin{array}{c}\text { Mole } \\
\text { Percent }\end{array}$} & \multicolumn{4}{|c|}{$\begin{array}{l}\text { Absorption Maxima }{ }^{\mathrm{d}} \\
(\mathrm{nm})\end{array}$} & \multirow{2}{*}{$\begin{array}{c}\text { Wavelength } \\
\text { Difference: } \\
\lambda_{2}-\lambda_{1}{ }^{\mathrm{e}} \\
(\mathrm{nm})\end{array}$} & \multirow{2}{*}{$\begin{array}{c}\text { Approximate } \\
\text { Ratio } \\
\lambda_{1} \lambda_{2} f\end{array}$} \\
\hline & & & $\begin{array}{c}\text { IV } \\
\text { "cis-peak" }\left(\lambda_{2}\right)\end{array}$ & III & $\begin{array}{c}\text { II } \\
\left(\lambda_{1}\right)\end{array}$ & 1 & & \\
\hline \multirow[t]{3}{*}{$10 \mathrm{G}-5,7.9-9.8$} & Tot. C & - & $335-340$ & (423) & 447.0 & 471.5 & $107-112$ & 33 \\
\hline & $\mathrm{Cl}$ & $18 \%$ & 338.0 & (421) & 444.0 & 468.0 & 106 & 5 \\
\hline & $\mathrm{C2}$ & $82 \%$ & $334-342$ & (426) & 449.5 & 474.5 & $107.5-115.5$ & 42 \\
\hline \multirow[t]{4}{*}{$10 \mathrm{G}-10,17.7-19.7$} & Tot. C & - & $335-340$ & (423) & 447.5 & 471.5 & $107.5-112.5$ & 40 \\
\hline & C1 & $6 \%$ & n.o. & (412) & 438.0 & 463.0 & - & - \\
\hline & $\mathrm{C} 2$ & $88 \%$ & 338.0 & (422) & 445.5 & 469.0 & 107.5 & 13 \\
\hline & $\mathrm{C} 3$ & $6 \%$ & $335-340$ & (426) & 449.5 & 474.5 & $109.5-114.5$ & 47 \\
\hline \multirow[t]{4}{*}{$474-2-3,120-150$} & Tot. C & - & obsc. & (424) & 445.5 & 470.0 & - & - \\
\hline & C1 & $12 \%$ & n.o. & (418) & 440.0 & 465.0 & - & - \\
\hline & $\mathrm{C} 2$ & $31 \%$ & 338.0 & (421) & 444.0 & 468.5 & 106 & 5 \\
\hline & C3 & $57 \%$ & $335-340$ & (425) & 449.5 & 474.5 & $109.5-114.5$ & 18 \\
\hline $477-5-1,120-140$ & Tot. C & - & 338.0 & (423) & 447.0 & 472.0 & 110.5 & 13 \\
\hline $479-3-2,110-130$ & Tot. C & - & $335-340$ & (425) & 448.5 & 474.5 & $108.5-113.5$ & 35 \\
\hline $479-5-3,125-150$ & Tot. C & - & $335-340$ & (424) & 448.5 & 473.5 & 108-113 & 34 \\
\hline \multirow[t]{4}{*}{$479-7-5,110-140$} & Tot. C & $\bar{a}$ & $335-340$ & (423) & 448.0 & 473. & $108-113$ & 28 \\
\hline & $\mathrm{Cl}$ & $3 \%$ & n.o. & 384.0 & 405.0 & 428.0 & - & - \\
\hline & $\mathrm{C} 2$ & $12 \%$ & 337.5 & (421) & 443.5 & 468.0 & 106 & 7 \\
\hline & $\mathrm{C} 3$ & $85 \%$ & $335-350$ & (427) & 449.5 & 475.5 & $99.5-114.5$ & 38 \\
\hline \multirow[t]{4}{*}{$479-9-2,125-140$} & Tot. C & - & obsc. & (423) & 447.0 & 472.0 & - & - \\
\hline & $\mathrm{Cl}$ & $4 \%$ & & 338.0 & 404.5 & 429. & - & - \\
\hline & $\mathrm{C} 2$ & $9 \%$ & 338.0 & (422) & 444.5 & 472.5 & 106.5 & 6 \\
\hline & C3 & $87 \%$ & $335-350$ & (426) & 448.5 & 474.5 & $98.5-113.5$ & 32 \\
\hline \multirow[t]{3}{*}{$479-13-1,110-140$} & Tot. C & - & obsc. & obsc. & 445 & 472 & - & - \\
\hline & $\mathrm{Cl}$ & $16 \%$ & & 381.0 & 405.0 & 428.5 & - & - \\
\hline & $\mathrm{C} 2$ & $84 \%$ & obsc. & (423) & 445.5 & 470. & - & - \\
\hline \multirow[t]{3}{*}{$479-15-5,110-140$} & Tot. C & - & obsc. & (424) & 446.0 & 472.5 & - & - \\
\hline & $\mathrm{Cl}$ & $8 \%$ & obsc. & 408 & 437.5 & 468. & - & - \\
\hline & $\mathrm{C2}$ & $92 \%$ & $335-350$ & (426) & 449.0 & 474.0 & $99-114$ & 26 \\
\hline \multirow[t]{2}{*}{$479-17-5,120-150$} & Tot. C & - & obsc. & obsc. & obsc. & 470 & - & - \\
\hline & $\mathrm{Cl}$ & $100 \%$ & 338.0 & (421) & 445.0 & 470.0 & 107 & $<5$ \\
\hline $479-19-5,115-140$ & Tot. C & - & $335-350$ & (425) & 449.0 & 474.5 & - & - \\
\hline \multirow[t]{3}{*}{$481-8-2,110-140$} & Tot. C & - & obsc. & (422) & 446.0 & 472.5 & 108 & 8 \\
\hline & $\mathrm{Cl}$ & $10 \%$ & 337.5 & (421) & 443.5 & 468.0 & 106 & 3.1 \\
\hline & $\mathrm{C} 2$ & $90 \%$ & $336-345$ & (424) & 448.5 & 473.0 & $103.5-112.5$ & 10 \\
\hline \multicolumn{9}{|c|}{ 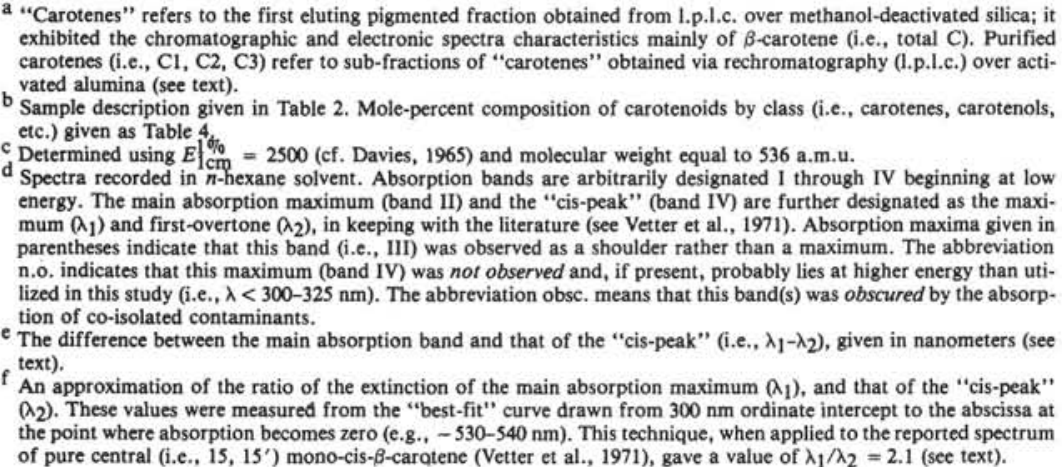 } \\
\hline
\end{tabular}

and several minor forms of dehydro-, didehydro-, and retro-dehydro- $\beta$-carotenes (e.g., XIV, XV); a monoepoxy $\beta$-carotene (XXVI); lycopene; echinenone (XXVIII: $\beta, \beta$-caroten-4-one); and one or more unidentified keto-carotenoids. For comparison, both fresh-viable and 2-month-post-mortum (dark storage, $20^{\circ} \mathrm{C}$ ) cultures of the diatom Synedra sp. (Carolina Biological Supply, U.S.A) were extracted, and pigments isolated according to the methods described herein (see materials and methods section). Of the pigments isolated from the Leg 64 diatomaceous sediment samples (i.e., within this grouping up to and including echinenone), only $\beta$-carotene (XXII) and one form (stereoisomer) of mutatochrome (XXVII) could be shown in recognizable amounts. Peaks in the region of the dehydro- and retro-carotenes appear to have increased slightly with the senescence and death of Synedra sp., but further study is required (Louda and Baker, unpublished results). Thus, it appears that of these early-eluting carotenoids only $\beta$-carotene (XXII) and mutatochrome (XXVII) are inherited directly from diatom sources, and the remainder either have other biotic sources or are diagenetic products.

The remainder of the carotenoids in the initial $2 \%$ acetone/petroleum ether eluate group were identified as dehydro-carotenes, $\beta$-carotene-monoepoxide (XXVI: 5,6 -epoxy-5,6-dihydro- $\beta, \beta$-carotene), and echinenone (XXVIII).

Of the dehydro-carotenes reported (Table 8), isolates number 2 and 3 vastly predominated $(>90 \%)$ and were present in essentially equal amounts. The band order, absorption maxima, and overall spectral characteristics lead us tentatively to identify these compounds as retrobisdehydro- $\beta$-carotenes (isolates $1-3$ ), bisdehydro- $\beta$-carotenes (isolates 4,5 ), and a single dehydro- $\beta$-carotene (6). In general, all of these forms were present in the sections reported as containing dehydrocarotenes (see Table 6).

Eluting between the dehydro-carotenes and echinenone was a compound tentatively identified as $\beta$-carotene-monoepoxide (XXVI: 5,6-epoxy-5,6-dihydro- $\beta, \beta$ - 
Table 8. Representative electronic absorption spectra of various carotenoids isolated from DSDP Leg 64 and Guaymas Basin Site Survey core samples. ${ }^{\mathrm{a}}$

\begin{tabular}{|c|c|c|c|c|c|c|c|}
\hline \multirow[b]{2}{*}{$\begin{array}{c}\text { Carotenoid }^{\mathrm{b}} \\
\text { (tentative identification) }\end{array}$} & \multirow[b]{2}{*}{ Solvent ${ }^{\mathrm{c}}$} & \multicolumn{5}{|c|}{$\begin{array}{l}\text { Absorption Maxima }{ }^{\mathrm{d}} \\
(\mathrm{nm})\end{array}$} & \multirow{2}{*}{$\begin{array}{c}\text { Band Order }{ }^{\mathrm{C}} \\
\text { (decreasing } \\
\text { extinction) }\end{array}$} \\
\hline & & $\begin{array}{c}\text { IV } \\
\left(\text { ("cis-peak, } " \lambda_{2}\right)\end{array}$ & IIIS & III & $\begin{array}{c}\text { II } \\
\left(\lambda_{1}\right)\end{array}$ & I & \\
\hline Mutatochrome 1 & hex & n.o. & - & (404) & 426.5 & 451.5 & II,I,III \\
\hline Mutatochrome 2 & hex & n.o. & - & (406) & 426.5 & 451.5 & II,I,(III) \\
\hline Dehydro- $\beta$-carotene-1 & hex & 370 & (404) & (454) & 478.0 & (506) & $\begin{array}{l}\text { II,(III),(I), } \\
\text { (IIIS),IV }\end{array}$ \\
\hline Bisdehydro- $\beta$-carotene-2 (f) & hex & 373 & (408) & (458) & 482.5 & 514.0 & $\begin{array}{l}\text { II,(III),I, } \\
\text { (IIS),IV }\end{array}$ \\
\hline Retro-dehydro-carotene-3 (f) & hex & 372 & - & $(462)$ & 482.5 & 514.5 & II,(III),I,IV \\
\hline Retro-dehydro-carotene-4 & hex & 336 & (402) & 456.0 & 482.0 & $(512)$ & $\begin{array}{l}\mathrm{II}=\mathrm{III} \text {,(IIIS) } \\
\text { (I),IV }\end{array}$ \\
\hline Retro-dehydro-carotene-5 & hex & $335=355<371$ & - & 459.0 & 486.5 & 520.5 & II,III,I,IV \\
\hline Retro-dehydro-carotene-6 & hex & - & (431) & 455.0 & 481.0 & 515.0 & III,II,(IIIS),I \\
\hline$\beta$-carotene-monoepoxide & hex & - & - & $(423.0)$ & 445.5 & 471.0 & II,III,(I) \\
\hline Echinenone (high-cis) & hex & 336 & - & - & 453.5 & (474) & II,(I),IV \\
\hline Echinenone & ETOH & 336 & - & - & 455.0 & (478) & II,(I),IV \\
\hline Echinenone, post BH4 & ETOH & 336 & - & 426 & 450.0 & 476.0 & II,III,I \\
\hline Unidentified-carotenone-1 & hex & obsc. & - & - & 454.0 & - & II \\
\hline Unidentified-carotenone-1 & $\mathrm{ETOH}$ & obsc. & - & - & 455.0 & - & II \\
\hline Unidentified-carotenone-1, post $\mathrm{BH} 4$ & ETOH & obsc. & - & (420) & 446.0 & 470 & II,I,(III) \\
\hline Unidentified-carotenone-2 & hex & obsc. & - & - & 448.5 & - & II \\
\hline Unidentified-carotenone-2 & ЕTOH & obsc. & - & - & 449.0 & - & II \\
\hline Unidentified-carotenone-2, post $\mathrm{BH} 4$ & ETOH & obsc. & - & $(420)$ & 442.0 & 469 & II,I,(III) \\
\hline Canthaxanthin & hex & - & - & - & 467.0 & - & II \\
\hline Carotenol-1 & hex & - & - & 423.5 & 445.0 & 471.5 & II,I,III \\
\hline Carotenol-2 & hex & - & - & $(425)$ & 450.0 & 474.5 & II,I,(III) \\
\hline Hydroxy-carotenone-1 & hex & - & - & - & 447.8 & (465) & $\mathrm{II},(\mathrm{d})$ \\
\hline Hydroxy-carotenone-1a & hex & - & - & - & 454.0 & (470) & II,(I) \\
\hline Hydroxy-carotenone-1b & hex & - & - & - & 454.0 & (470) & II,(I) \\
\hline Carotene-diol-1 & hex & - & - & $(430)$ & 452.0 & 478.0 & II,1,(III) \\
\hline Carotene-diol-2 & hex & (ca. 325-328) & - & 425.0 & 449.5 & 475.5 & II,I,III \\
\hline Carotene-diol-3 (ca. 5 isomers) & hex & obsc. & - & 425.0 & 451.0 & 475.0 & $\mathrm{II}, \mathrm{I}=\mathrm{III}$ \\
\hline Epoxy-carotene-diol-1a & hex & - & - & (426) & 447.0 & 472.5 & II,I,(III) \\
\hline Epoxy-carotene-diol-1 & ETOH & - & - & (425) & 446.0 & 473.0 & II,I,(III) \\
\hline Epoxy-carotene-diol-1b & hex & - & - & (425) & 446.0 & 474.0 & II,I,(III) \\
\hline Epoxy-carotene-diol-1b & ETOH & - & - & (423) & 446.0 & 473.5 & II,I,(III) \\
\hline
\end{tabular}

carotene). The absorption spectrum (Table 8) of this isolate matches the literature (cf. Foppen, 1971), and a hypsochromic shift, compared to all-trans- $\beta$-carotene (XXII), of about $5 \mathrm{~nm}$ is consistent with the introduction of the 5,6-epoxy grouping (cf. Vetter et al., 1971).

Echinenone (XXVIII: $\beta, \beta$-caroten-4-one) was found to be a major (i.e., $>10 \%$ ) carotenoid only in a nearsurface $(0.187 \mathrm{~m}$ sub-bottom) gravity core (10G-10; Tables 2 and 6). Echinenone (XXVIII) also was found to have disappeared with depth (15.0-57.6 m sub-bottom) at Site 479 (see Table 6). Identification of echinenone (XXVIII) was based on chromatographic position in reference to authentic echinenone (XXVIII), electronic spectroscopy (see Table 8 ), and a positive reaction to borohydride reduction, which yielded a product identical in all criteria to known isocryptoxanthin (XXX). That is, the reduction of echinenone (XXVIII) established carotene-like fine structure in the electronic spectrum with maxima at 450.0 and 476.0 and a sharp inflection at about $426 \mathrm{~nm}$ in ethanol. A marked peak at $336 \mathrm{~nm}$ may indicate that echinenone (XXVIII) from Site 479 and $10 \mathrm{G}$ sediments is a mixture of cis- and trans-isomers but is inconclusive at present.

Several minor peaks in 1.p.l.c. chromatograms of the pigments from less deeply buried sediments (e.g., 10G$10,479-2-3$ through $479-7-5)$ tentatively were identified as keto-carotenoids (carotenones) on the basis of electronic spectra lacking fine structure, positive reaction to borohydride (see Table 8), and chromatographic behavior.

Canthaxanthin (XXIX: $\beta, \beta$-carotene- $4,4^{\prime}$-dione) eluted just prior to the carotenols and exhibited a symmetrical absorption spectrum with the maximum at $467.0 \mathrm{~nm}$ in $n$-hexane (Table 8). Canthaxanthin (XXIX) could be verified only in Section 474-2-3 (Table 6), though impure isolates from Sections 10G-5, 10G-10, and 479-2-3 through 479-7-5 (cf. Tables 2 and 6) may yield canthaxanthin (XXIX) upon further study.

Other than the carotenes, the carotenols, carotenediols, and epoxy-carotene-diols formed the major carotenoids. Typically, one or two carotenols eluted between echinenone (XXIX) and pheophytin-a (I) from silica 1.p.1.c. The major carotenol in all cases (see Table 6) eluted with a retention time similar to that of known isocryptoxanthin (XXX: $\beta, \beta$-caroten-4-ol); however, on the basis of electronic spectra (Table 8) of carotenol-I, a more likely identification would be cryptoxanthin (XX$\mathrm{XI}$ : $\beta, \beta$-caroten-3-ol) for the major carotenol. A less common isolate (i.e., carotenol-II; Table 8) is more similar to isocryptoxanthin (XXX), or perhaps $\alpha$-cryptoxanthin $(\beta, \Sigma$-caroten-3'-ol).

Following elution of pheophytin-a (i.e., form 2:I), and often overlapping the tail of this tetrapyrrole, a variety of minor hydroxy-carotenones were isolated. Purity of these isolates was low, yet the spectral shape (i.e., lack of fine structure, with pronounced shoulder- 
ing at band I; see Table 8), is extremely reminiscent of compounds such as 4 '-hydroxy-echinenone (4'-hydroxy$\beta, \beta$-carotene-4-one).

Several carotene-diols eluted from silica 1.p.l.c. with long retention times between 5 and $10 \%$ acetone in petroleum ether. The lower solvent strength required to elute carotene-diols and the epoxy-carotene-diols than usually reported (e.g., 30-40\% acetone; cf. Fiksdahl et al., 1978) is probably a reflection of our use of $20 \%$ methanol in acetone as a column cleaner (i.e., flush). That is, methanol is known to deactivate chromatographic silica (see Purcell, 1958). Through comparing chromatographic mobility of the carotene-diols isolated from Leg 64 samples to those reported from other studies (e.g., see Fiksdahl et al., 1978; Hajibrahim et al., 1978 ) and to the known position of authentic chlorophyll-a on the system used herein with that reported by others (Fiksdahl et al., 1978), these compounds appear to be zeaxanthin-like (XXXII: $\beta, \beta$-carotene-3,3'-diol) and diatoxanthin-like (XXXIII: 7,8-didehydro- $\beta, \beta$-carotene-3,3'-diol) compounds. However, further study and mass spectrometric analyses are required before assigning definite structure.

The most polar carotenoids isolated have been assigned as epoxy-carotene-diols and poly-hydroxy compounds most likely containing acetylenic or allenic carbon bonds within the main skeleton. Similarities to diadinoxanthin (XXXIV: 5,6-epoxy-5,6-dihydro-7' ${ }^{\prime} 8^{\prime}$-didehydro- $\beta, \beta$-carotene- $3,3^{\prime}$-diol), heteroxanthin $\left(7^{\prime}, 8^{\prime}\right.$-didehydro- $\beta, \beta$-carotene-3,4,6,3' -tetrol), and neoxanthin $\left(5^{\prime}, 6^{\prime}\right.$-epoxy-6,7-didehydro- $5,6,5^{\prime}, 6^{\prime}$-tetrahydro- $\beta,-$ $\beta$-carotene-3,5,3' -triol) are noted. The highest degree of correlation, chromatographically and spectrally, between the epoxy-carotene-diol isolates (i.e., Ia and Ib; Table 8) is with diadinoxanthin (XXXIV), as similar compounds were isolated from the diatom Synedra sp. discussed earlier.

Fucoxanthin (XXXV: 5,6-epoxy-3,3', $5^{\prime}$-trihydroxy$6^{\prime}, 7^{\prime}$-didehydro- $5,6,7,8,5^{\prime} 6^{\prime}$-hexahydro- $\beta, \beta$-caroten8 -one- $3^{\prime}$-acetate) is easily identified via electronic spectroscopy, because of the rather complete loss of fine structure in ethanol solution as compared to spectra recorded in $n$-hexane or petroleum ether solvents. Fucoxanthin (XXXV), per se, could not be shown in even the shallowest diatomaceous oozes examined (i.e., 10G-5, 10G-10; see Table 2). This is most likely an expression of the lability of fucoxanthin (XXXV) to acids, alkali, and oxygen (see, e.g., Bonnett et al., 1969; Liaaen-Jensen, 1971). Thus, it is likely that many of the carotene-diols and epoxy-carotene-diols discussed herein are alteration products of fucoxanthin (XXXV), the most abundant diatom carotenoid (see Goodwin, 1976; Hager and Stransky, 1970).

The ratio of hypophasic to epiphasic carotenoids (i.e., $H / E, 95 \%$ methanol-petroleum ether partition; see Schwendinger and Erdman, 1963; Vallentyne, 1960) is routinely employed to assess the relative amounts of polar (e.g., carotenols, "xanthophylls") versus nonpolar (e.g., carotenes) carotenoids in biota as well as sediments. In general, marine organisms, zoo- as well as phytoplankton, store a predominance of oxygen-con- taining carotenoids ("xanthophylls") and yield $H / E$ values of $4: 1$ to $14: 1$ (cf. Vallentyne, 1960, and references therein). However, in sediments the $H / E$ values obtained for carotenoids are considerably less (Schwendinger and Erdman, 1963) and decrease with depth (Fox et al., 1944). That "these data clearly indicate a preferential degradation of xanthophylls" (Vallentyne, 1960) is now a rather well accepted fact. The data obtained during studies on Leg 64 samples reinforce this concept. Reported as part of Table 6 is the ratio of the sum of oxygen-containing carotenoids to the sum of the hydrocarbon carotenoids (i.e., carotenes). This value is not directly equal to the $H / E$ value, because the mono-oxo carotenoids, like echinenone, are primarily epiphasic to petroleum ether-95\% methanol partition (see Foppen, 1971; Kirnsky, 1963; Petracek and Zechmeister, 1956), but the principle and trends will be the same. All of the values obtained are substantially lower than for living phyto- and zooplankton and marine seston (cf. Vallentyne, 1960), and are greater than unity only in two cases (i.e., 479-7-5 and 481-2-2; Table 6). Only with the sample suite from Site 479 was more than one sample rich enough in tetraterpenoid pigments for complete analyses. Here, eight sections from 15.0 to 171.6 meters subbottom (Table 6) provided examination of the losses of the various carotenoid classes with depth. Oxygen-containing carotenoids were indeed more rapidly destroyed than were the carotenes. A point which will be further investigated is the possibility that carotenols and carotene-diols may become dehydrated and yield pigments such as the dehydro- and retro-didehydro-carotenes reported herein.

\section{Perylene}

The polyaromatic hydrocarbon perylene was found to be a ubiquitous component of all Leg 64 samples investigated, except those in which igneous activity has led to complete destruction of pigments (i.e., 477-16-5, 477-20-1, 481A-13-6; Table 2).

Perylene eluted just following $\beta$-carotene (XXII) during silica l.p.l.c. developed with $n$-pentane/petroleum ether $(2: 3, \mathrm{~V} / \mathrm{V})$. Electronic absorption maxima were $(\sim 360), 385.5,407.5,434.5 \mathrm{~nm}$, and $(\sim 370), 390.5$, $412.5,439.5 \mathrm{~nm}$, in ethyl ether and benzene, respectively. This matches authentic perylene and geologic isolates reported previously (Louda and Baker, 1981). Near-surface samples (10G-10, 474-2-3; Table 2) yielded much less perylene than the other, more deeply buried (e.g., $>6.2 \mathrm{~m}$ ) samples. This tends to reinforce the idea that, in surface sediments, perylene increases with depth (see, e.g., Wakeham et al., 1980). However, the lack of any significant downhole trend in the more deeply buried sediments from any site, even when perylene is normalized to organic carbon, indicates that perylene "production" must cease within the first several meters of burial and thereafter remain steady, reflecting the initial formation, or decrease.

Examining perylene yields from the sample suites reported (Table 2), we find random downhole fluctuations. This we take to reflect early diagenetic transformation or alteration in input, rather than continued 
diagenetic formation or increasing destruction. Figure 5 is a plot of perylene yield and organic-carbon content versus sub-bottom depth at Site 479 . No trend is immediately apparent, until shipboard analyses of hydrogen sulfide $\left(\mathrm{H}_{2} \mathrm{~S}\right)$ content (site reports, this volume) are examined. Because $\mathrm{H}_{2} \mathrm{~S}$ is lost with depth as metallic sulfides, etc., data are available only for the uppermost 100 to 125 meters; however, the coincidence of a low $\mathrm{H}_{2} \mathrm{~S}$ content with a perylene maximum at 72.0 meters and the marked perylene minima with high $\mathrm{H}_{2} \mathrm{~S}$ values may offer a clue as to the source and formation of perylene. That is, if this observed correlation is correct, then the potential for perylene generation or the source of (unknown) perylene precursors may derive from the activities of aerobic or microaerophilic marine benthic microbes, and is in line with suggestions by others (cf. Wakeham et al., 1979). Attempts to relate perylene quantities to the abundance of diatoms, clay, silt, wet water, organic carbon, temperature, and combinations of these proved futile. To date, no verified explanation as to the source of perylene exists. Erythroaphin, a terrestrial pigment of insects and fungi, has been offered as a possible perylene precursor (Aizenshtat, 1973). However, comparing other product-precursor pairs for geologic aromatics indicates that erythroaphin is a much more likely precursor to coronene (Baker and Louda, 1981). More likely precursors to perylene must include the less-complex perylene quinones such as cercosporin, which occurs in certain moulds (see Thomson, 1976). In this case-cercosporin-no carbon-carbon bonds need

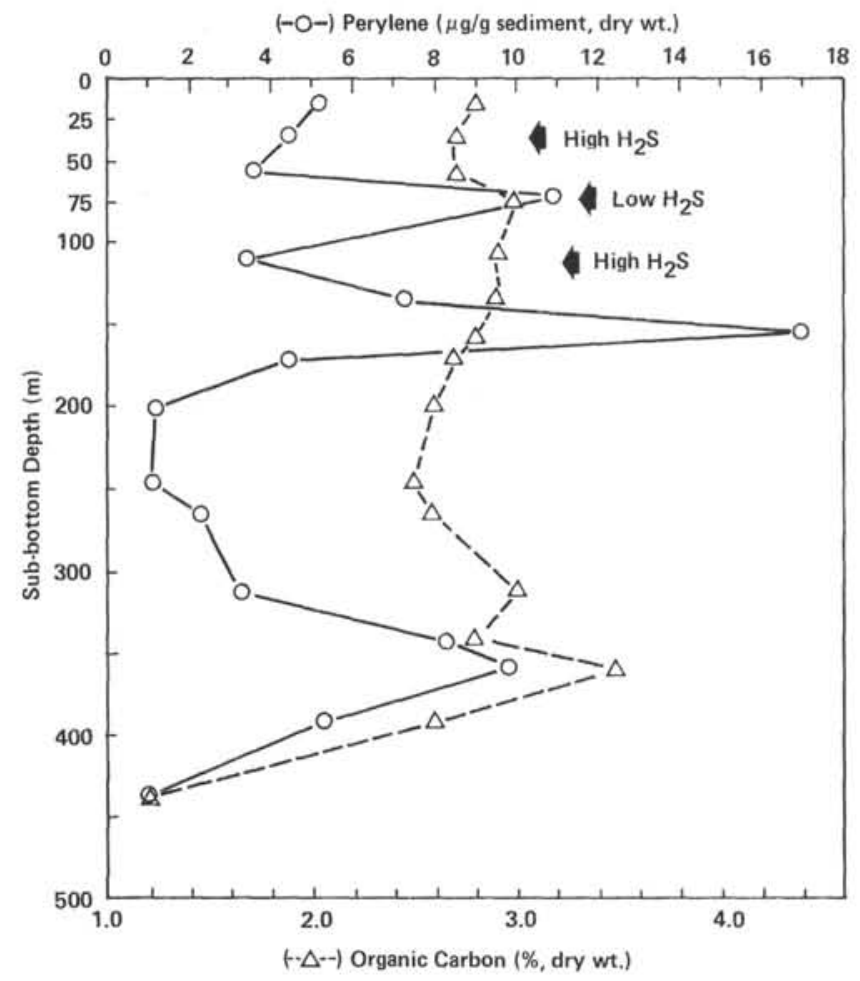

Figure 5. Perylene yield versus sub-bottom depth for sediments from DSDP Site 479. Organic-carbon and hydrogen sulfide data from site reports (this volume). to be broken, as in the case of erythroaphin, in order to yield perylene. To date, the precursor to perylene remains an enigma.

Two additional PAH compounds have been isolated from Site 479 sediments. Though work is still in progress on these pale-yellow-blue to blue-green, fluorescent materials, certain salient features can be elaborated. Both PAH " $A$ " and " $B$ " are more polar than perylene, requiring about $0.5 \%$ acetone in petroleum ether to elute from silica 1.p.l.c. During isocratic elution of this pair of unknowns, "A"' is less polar than " $\mathrm{B}$," and they separate well. Qualitatively, the electronic spectrum of each resembles a pigment with a perylene-like chromophore. Absorption maxima are located at 431.5 and 407.0 , and a shoulder is located at about $385 \mathrm{~nm}$, in benzene, for unknown "A." Unknown "B" has the similar maxima at 445.0 and 418.0 , and a shoulder at about $405 \mathrm{~nm}$. 14-eV mass spectra of both compounds show only three ions above $100 \mathrm{~m} / z$; these are 338 $\left(\mathrm{M}^{+}\right), 265(\mathrm{M}-73)$ and $352(\mathrm{M}+14$; a higher alkyl homo$\log ) \mathrm{m} / z$. High-energy mass spectra $(70 \mathrm{eV})$ yield these same ions as being major, but accompanied by 310 (M-28) and 292 (M-46), and a complex ion cluster at 279 (M-59) and 275 (M-63) $\mathrm{m} / \mathrm{z}$. The relationship of $\mathrm{M}+2$ peaks to $\mathbf{M}$, as well as fragment clusters, shows that only predominately monoisotopic elements are present. This then precludes the possibility of " $A$ " and " $B$ " being sulfide, halogen or metallo- (e.g., $\mathrm{Cu}, \mathrm{Ni}, \mathrm{Zn}$ ) complexes. Losses indicate the elements of $\mathrm{C}_{3} \mathrm{H}_{5} \mathrm{O}_{2}$ (alt. $\mathrm{C}_{4} \mathrm{H}_{9} \mathrm{O}$ ), most likely present as proprionic acid, methyl acetate, acetoxy plus a ring-conjugated oxo-moiety (i.e., ketone), or several possible cyclic ethers (epoxides). Infrared spectroscopy and derivatization studies are planned with these unknowns. These compounds appear to be perylene-based and may be less-conjugated analogs of such compounds as the quincyte dyes reported from the sediments of an Eocene lake (see Watts et al., 1977).

Though the source of perylene is unknown, one aspect of its geochemistry is rather straightforward. That is, perylene becomes more highly alkylated with increasing thermal stress (Baker and Louda, 1981; Louda and Baker, 1981). Presented as Table 9 are the mass spectra of perylene(s) isolated from Leg 64 samples. In general, it can be seen that the alkylated perylenes increase in abundance with increasing sub-bottom depth. In the previous report (Louda and Baker, 1981), we first related the alkylation of perylene to thermal stress. Figure 6 is a comparison of the downhole profiles obtained when the alkylation indices for perylene (cf. Table 9, note d) are plotted versus present in situ temperatures. For comparison, the profile obtained from Leg 63 investigations (Louda and Baker, 1981) is provided. Thus, it was observed that in the sediments studied from Leg 63 , the most intense alkylation of perylene was found to have occurred (is occurring) in Miocene sediments presently at about 35 to $40^{\circ} \mathrm{C}$. In the present study, the alkylation of perylene was found to occur at about 40 to $50^{\circ} \mathrm{C}$ in the Quaternary and late Pliocene sediments from Sites 474 and 479 . Thus, the alkylation of perylene has been found to occur at higher temperatures in geo- 


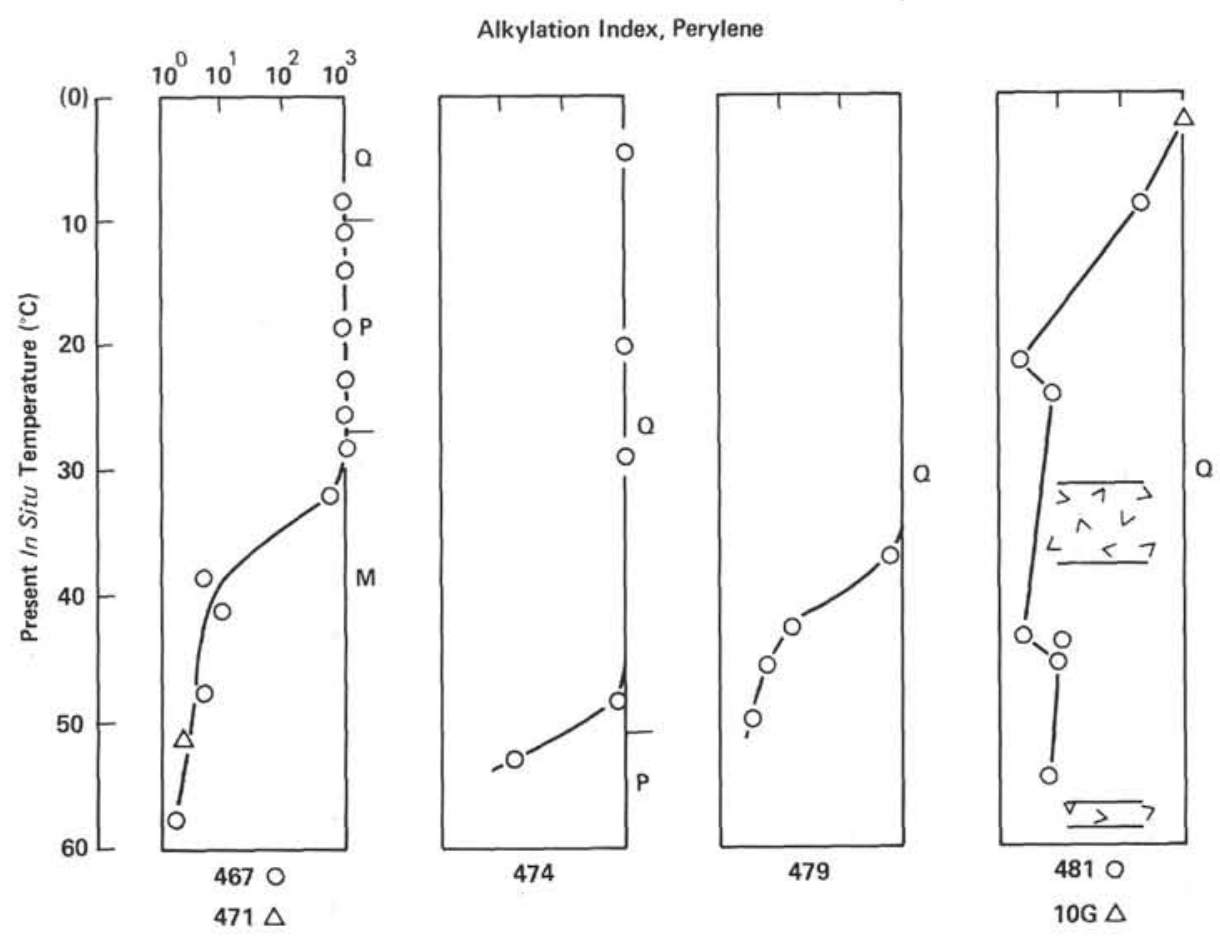

Figure 6. Alkylation indices versus present in situ temperature obtained for perylene isolates from DSDP Leg 64 sediment samples (Sites 474, 479, 481, and 10G). DSDP Leg 63 data (Sites $467-471$ ) co-plotted as reference. (Alkylation index is equivalent to the relative intensity of perylene [C-20], divided by the sum of relative intensities for the alkylated perylenes [C-21, C-22, C-23, etc.] $\mathrm{M}=$ Miocene; $\mathrm{P}=$ Pliocene; $\mathrm{Q}=$ Quaternary. .

Table 9. Normalized 14-eV mass spectra of perylene(s) ${ }^{\mathrm{a}}$ isolated from DSDP Leg 64 sediment samples.

\begin{tabular}{|c|c|c|c|c|c|c|}
\hline \multirow[b]{2}{*}{ Hole-Core-Section ${ }^{b}$} & \multicolumn{5}{|c|}{$\begin{array}{l}\text { Normalized Intensity } \\
\left(m / e \text { designation }{ }^{c}\right)\end{array}$} & \multirow[b]{2}{*}{$\begin{array}{l}\text { Alkylatior } \\
\text { Index }\end{array}$} \\
\hline & $\begin{array}{c}252 \\
P\end{array}$ & $\begin{array}{l}266 \\
C_{1} P\end{array}$ & $\begin{array}{l}280 \\
\mathrm{C}_{2} \mathrm{P}\end{array}$ & $\begin{array}{l}294 \\
\mathrm{C}_{3} \mathrm{P}\end{array}$ & $\begin{array}{l}308 \\
\mathrm{C}_{4} \mathrm{P}\end{array}$ & \\
\hline $10 G-10$ & 100.0 & - & - & - & - & $\infty$ \\
\hline $474-2-3$ & 100.0 & - & - & - & - & $\infty$ \\
\hline $474-17-6$ & 100.0 & - & - & - & - & $\infty$ \\
\hline $474 \mathrm{~A}-7-2$ & 100.0 & - & - & - & - & $\infty$ \\
\hline $474 \mathrm{~A}-28-2$ & 100.0 & Tr. & - & - & - & $<\infty$ \\
\hline $474 A-32-2$ & 100.0 & 4.5 & 0.8 & - & - & 18.87 \\
\hline $477-5-1$ & 100.0 & 6.6 & 2.1 & - & - & 11.49 \\
\hline $479-39-4$ & 100.0 & 4.1 & 0.8 & 0.5 & - & 18.52 \\
\hline $479-43-1$ & 100.0 & 8.4 & 3.6 & 0.1 & - & 8.33 \\
\hline $479-47-4$ & 100.0 & 9.6 & 2.6 & 1.4 & 0.5 & 7.09 \\
\hline $481-8-2$ & 100.0 & 5.6 & 1.7 & - & - & 13.70 \\
\hline $481 \mathrm{~A}-8-2$ & 100.0 & 20.8 & 14.7 & 0.6 & - & 2.77 \\
\hline $481 \mathrm{~A}-10-2$ & 100.0 & 5.9 & 5.4 & 0.4 & - & 8.55 \\
\hline $481 \mathrm{~A}-22-4$ & 100.0 & 18.0 & 19.6 & 0.9 & - & 2.60 \\
\hline $481-24-5$ & 100.0 & 6.0 & 3.7 & 0.4 & - & 9.90 \\
\hline $481 \mathrm{~A}-30-5$ & 100.0 & 7.6 & 4.5 & 0.3 & - & 8.06 \\
\hline
\end{tabular}

a Averaged and normalized mass spectra determined at $14 \mathrm{eV}$ and covering the entire volatility of sample from solid probe EI-MS (see Louda and Baker, 1981).

b For sample description, pigment yields, etc., see Table 2.

$c_{\mathrm{P}}=$ perylene: $\mathrm{C}_{1} \mathrm{P}=$ methyl perylene: $\mathrm{C}_{2}, \mathrm{C}_{3}, \mathrm{C}_{4}=$ alkylated perylenes with 2,3 , or 4 additional methylene equivalents.

d Defined here as the intensity of perylene divided by the sum of the intensities of alkylated perylenes.

logically younger sediments and, as such, follows the time-temperature dicta of thermal reactions. The pattern of perylene alkylation within Site 481 strata was found to have been randomized, and this effect is at- tributed to the emplacement of igneous sills at the positions indicated in Figure 6. The near-surface sample from Site 10G (site survey cruise; see materials and methods section and Table 2) was co-plotted with Site 481 data as a surface reference. The effect of igneous intrusion upon other organic compounds and mixtures (i.e., metalloporphyrins, kerogen) has been described (Baker et al., 1978a) from Leg 41 post-cruise investigations. That igneous activity has imposed variant thermal stress upon Site 481 sediments is evident from the random alkylation of perylene within this profile.

Overall, the alkylation of perylene in sedimentary strata free from igneous intrusion, variant hydrothermal influences, or reworking is found to proceed with increasing thermal stress and may serve as an indicator of the thermal history of those sediments (cf. Baker and Louda, 1981; Louda and Baker, 1981).

\section{SUMMARY AND CONCLUSIONS}

\section{Diagenesis of Tetrapyrrole Pigments}

The sediments recovered by DSDP Leg 64 operations have provided a very complete overview of the early to mid-diagenesis of chlorophyll-that is, defunctionalization of pheophytin-a (I), aromatization of phorbides to free-base porphyrins, and chelation of nickel-yielding nickel-DPEP-type porphyrins.

As this report is preliminary and mass spectrometric analysis of metalloporphyrin isolates is still underway, only certain features of the metallo- pigments have been uncovered to date. The vast majority of metalloporphyrin arrays isolated from Leg 64 samples contain a 
copper and nickel ETIO-porphyrin component, as determined by chromatographic and electronic spectral characteristics. These pigments most likely derive from a previously oxidized source with a separate diagenetic history (e.g., terrestrial reworked; cf. Louda and Baker, 1981; Palmer and Baker, 1978). Only in the deepest sections of Site 479 (e.g., 479-37-5 through 479-47-4; see Tables 2, 3, and 5) do metalloporphyrin arrays assume the character of predominately NiDPEP porphyrins, indicating in situ diagenetic formation. The presence of decarboxylated nickel phylloerythrin (7-ethyl-7-desproprio-nickel-phylloerythrin cf. XVI) in sediments from all sites (i.e., $474,477,479$, and 481 ) is taken as indicating that in situations with high heat flow and rapid sedimentation a substantial portion of tetrapyrrole pigments retain the 9-keto moiety, inherited from biotic chlorophyll, past the aromatization and chelation stages.

Results from analyses of near-surface samples from all sites and the entire sample suite from Site 479 have yielded valuable insight into the variant pathways of early chlorophyll diagenesis in marine sediments.

Three forms of pheophytin-a have been isolated from Leg 64 sediment samples. These tentatively have been identified as pyropheophytin-a (i.e., 10-decarbomethoxy-pheophytin-a: II), "true" pheophytin-a (I), and allomerized pheophytin-a (i.e., 10-hydroxy-pheophytina: III). We believe that the formation of these various forms, and possibly of the analogous pheophorbides, dictates (i.e., fates) the subsequent diagenesis of tetrapyrrole pigments.

The formation of allomerized phorbides (i.e., 10-oxy forms of pheophytin-a: III, pheophorbide-a: VI) is known to be an initiating reaction in the oxidative scission of the isocyclic ring and yields either purpurins or chlorins as initial products, depending upon reaction conditions (see Hynninen, 1979; Seely, 1966). It is conceivable that, given sufficient original chlorophyllous input, such oxidative pathways can generate small amounts of ETIO porphyrins with further maturation (Louda and Baker, 1980, 1981). That similar reactions occur in oxidizing geologic situations is apparent from the isolation of purpurin-18 (XIX: see Appendix B) and chlorin- $\mathrm{p}_{6}(\mathrm{XX})$ from the upper sediments of Sites 10G, 474,477 , and 481 (see Table 3). The occurrence of minor amounts of allomerized pheophytin-a (III) and purpurin-18 (XIX) in the uppermost sample from Site 479 (i.e., 479-3-2, 110-130 cm) is taken as reflecting input of chlorophyll derivatives oxidized during residence in the water column and prior to entering the oxygen minimum, currently at Site 479.

As previously suggested (Baker and Louda, 1980a; Louda et al., 1980), the oxidative opening of the isocyclic ring appears to destabilize the tetrapyrrole macrocycle in such a manner as to render these pigments amenable to further reaction (destruction). At present, the mechanism of destruction of tetrapyrrole pigments is unknown, and this fact is incorporated into scheme I (Fig. 7), the proposed alteration of sedimentary chlorophyll in oxic settings.

The early stages in the reductive diagenesis of chlorophylls, eventually yielding quite stable biologic markers (i.e., $\mathrm{Ni}$ and $\mathrm{V}=\mathrm{O}$ porphyrins) has, to date, been difficult to study, this being primarily due to the lack of a fortuitous sample suite of organically rich sediments with a proper maturity continuum. Site 479 , located within the oxygen minimum northeast of the Guaymas Basin, is the profile needed. Though studies on the more-polar fractions (e.g., pheophorbides) are still underway, several valuable data have been obtained from the Site 479 sample suite (16 samples, $15.0-436.1 \mathrm{~m}$ subbottom; see Tables 2 and 3). Data from shipboard analyses reveals a bottom-water temperature of $7.9^{\circ} \mathrm{C}$ and a simple temperature profile for underlying sediments of $95.9^{\circ} \mathrm{C} / \mathrm{km}$ (site reports, this volume). These data have been employed in describing the thermal regimes in which the following diagenetic reactions of the tetrapyrrole pigments have occurred.

Earlier studies show that magnesium is lost from chlorophyll during settling out of the photic zone in the water column (Louda and Baker, unpublished data; Yentsch, 1965). Thus, in marine (aquatic) sedimentary situations with the sediment/water interface below the photic zone (especially photosynthetic compensation point), the primary tetrapyrrole input to sediments is pheophytin-a (I). Pheophytin-a (I) often is accompanied by variable amounts of other chlorophyll derivatives (e.g., pheophorbide-a: IV, purpurin-18: XIX), depending upon the biotic and abiotic factors (i.e., predation, consumption, oxygen tension, etc.) encountered during post-senescent residence in the overlying waters (Louda and Baker, unpublished data). Thus, the diagenesis of tetrapyrrole pigments will be defined as initiating with pheophytin-a (I) and pheorphorbide-a(IV).

Pigments which were isolated and tentatively identified from Site 479 samples and which, we feel, figure directly in the diagenesis of pheophytin-a (I) leading to metalloporphyrins (NiDPEP) are (see scheme II; Fig. 8) pheophytin-a (I), pyropheophytin-a (II), 7-ethyl-7-desproprio-meso-(alt. 2-methyl-2-desvinyl)-pyropheophorbide-a (X), 7-ethyl-7-desproprio-meso (alt. 2-methyl-2desvinyl)-desoxopyropheophorbide-a XIII, XIV), desoxophylloerythroetioporphyrin (XIV: i.e., free-base DPEP), nickel 7-ethyl-7-desproprio-phylloerythrin (cf. XVI), and metalloporphyrins dominated by NiDPEP (see Table 3).

A pigment designated as "Phorbide-686.5" (Table 3; Fig. 2C) was isolated from Section 479-5-3 and tentatively has been identified as a 2-acetyl-2-desvinyl derivative of pheophytin-a (VII), which may or may not retain the phytyl ester linkage but which is not the free acid (i.e., not 2-acetyl-2-desvinyl-pheophorbide-a). Oxidation at the 2-vinyl moiety, most notably at the alphacarbon, implies an anti-Markovnikov reaction and has profound implications concerning the homologies of DPEP isolated from more-mature sediments. That is, we routinely report free-base DPEP porphyrins and immature metalloporphyrins (i.e., $\mathrm{Ni}, \mathrm{V}=\mathrm{O}$ ) as being not only composed of C-32 ("true" DPEP; cf. Quirke et al., 1979), but also accompanied by large, sometimes dominant, quantities of C-31 homolog(s) (desmethylDPEP: see, e.g., Baker et al., 1978a, b; Louda and Baker, 1981). Thus, "Phorbide-686.5," identified as a 2acetyl-9-keto-phorbide, affords the first indication that 
E. W. BAKER, J. W. LOUDA

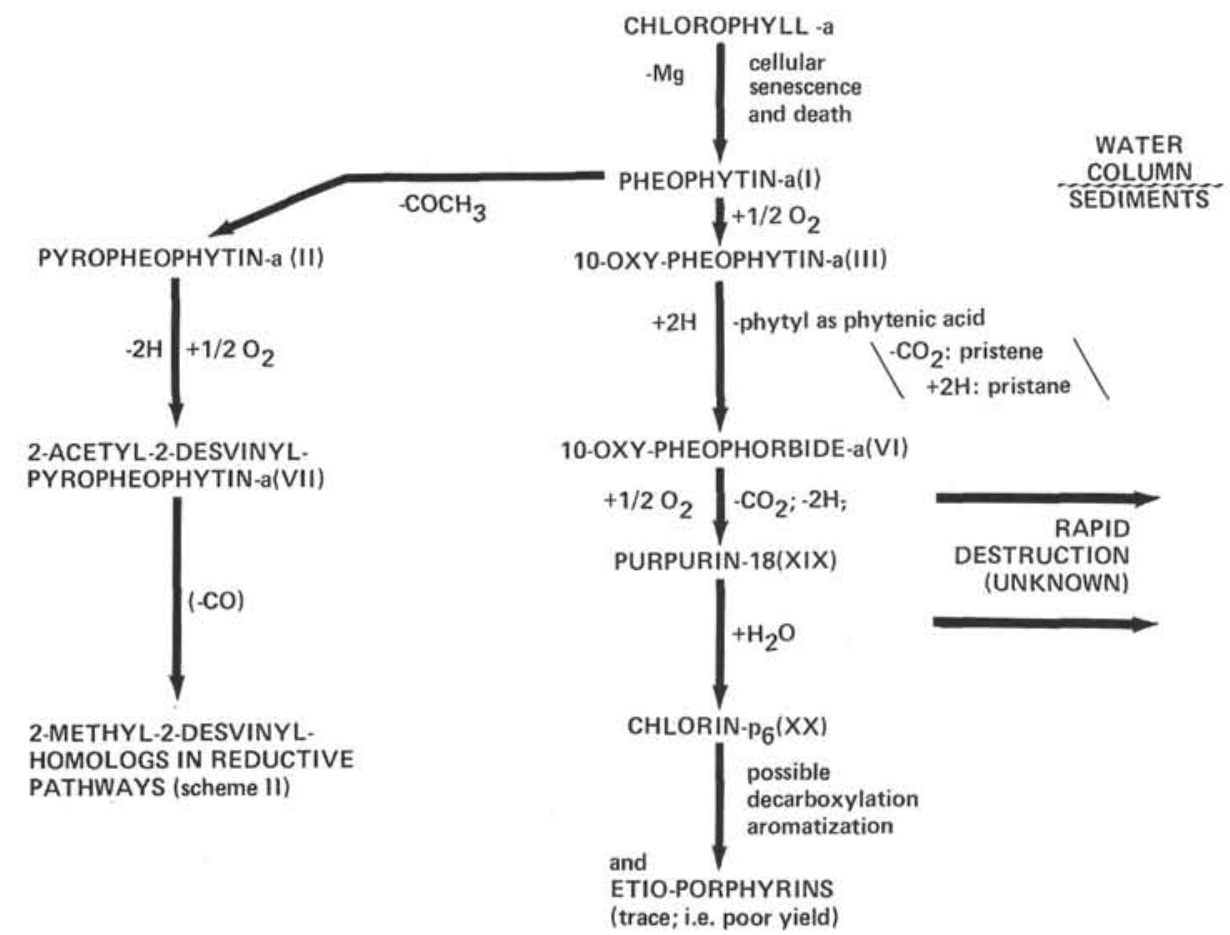

Figure 7. Proposed oxidative (oxic) diagenesis of chlorophyll derivatives in marine sediments.
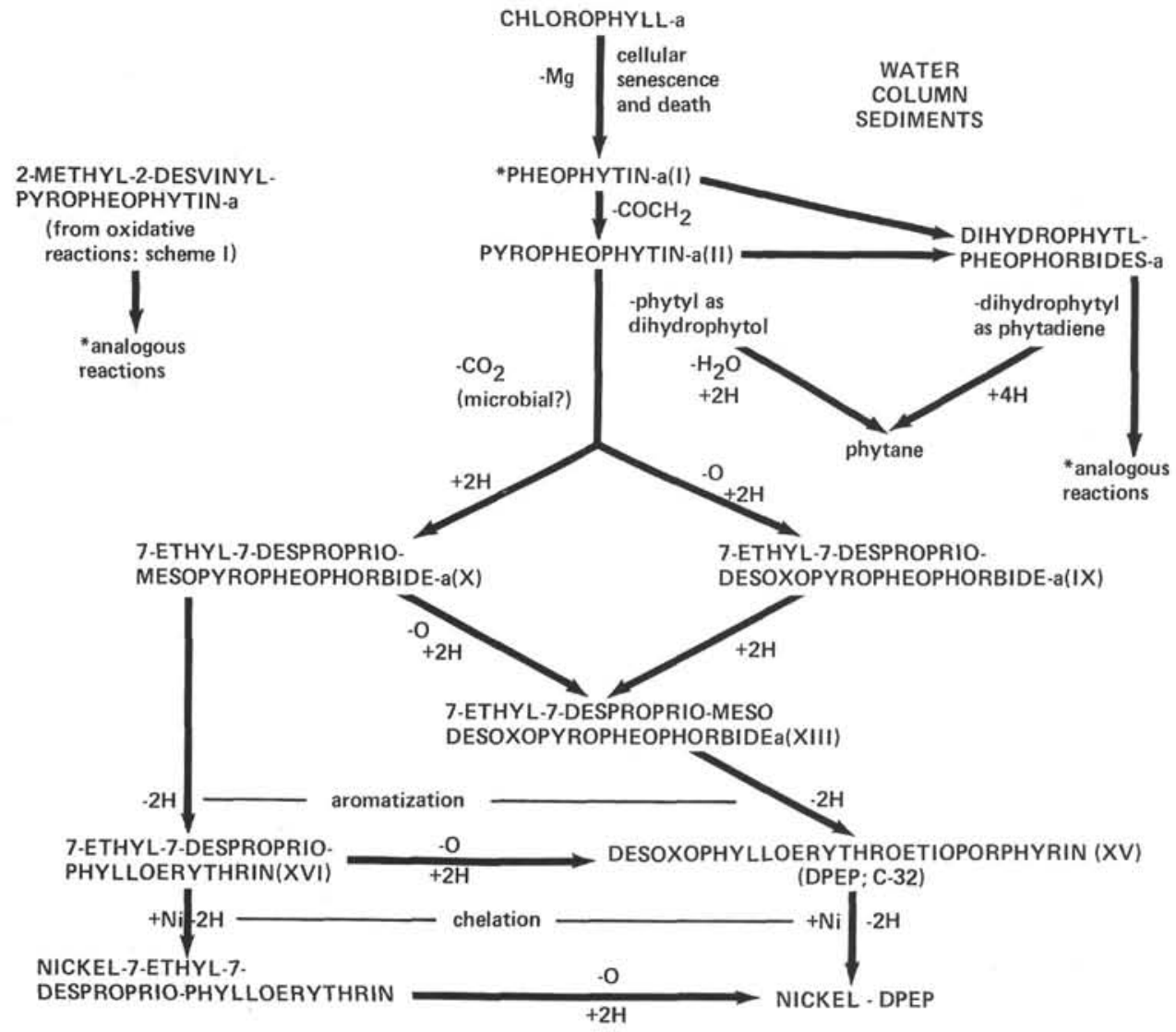

Figure 8. Proposed reductive (anoxic) diagenesis of chlorophyll derivatives in marine sediments. 
this initial methylene loss may occur by oxidation of the 2-vinyl moiety.

Aside from the minor occurrences of "Phorbide663 ,' shown previously to be a 9-keto-phorbide (Baker and Louda, 1980), and "Chlorin-636," thought to be a secondary chlorin (Baker and Louda, 1980; Louda and Baker, 1981; cf. Blumer and Omenn, 1961), two isolates from Site 479 pose questions. These are "Chlorin-660complex" and Ni-7-ethyl-7-desproprio-phylloerythrin (see Table 3).

First, "Chlorin-660-complex" is impossible, to date, to purify to a stage which yields an electronic spectrum typical of a purified pigment, in contrast with other tetrapyrrole pigments. Based on the arguments given earlier (see results and discussion), this compound(s) may be a large molecular complex, containing a tetrapyrrole pigment(s). If this is the case, then this concept of a bound tetrapyrrole is in line with other such suggestions (Louda and Baker, 1981; Mackenzie et al., 1980). Vanadyl porphyrins appear to arise via a separate pathway, in relation to the nickel species, and such phenomena as "chlorin-660 complex" may explain the appearance of the vanadyl chelates only after sufficient thermal stress has been applied (cf. Baker et al., 1978a; Louda and Baker, 1981; Mackenzie et al., 1980). Further, the electronic spectrum of "chlorin-660-complex" is reminiscent of immature humic acids (see Brassell et al., 1980), and the "cracking" of such pigmented complexes may also explain why chlorophyll derivatives appear to "move from the humic to solvent-soluble fractions during diagenesis"' (cf. Sato, 1980).

The decarboxylated form of $\mathrm{Ni}$ phylloerythrin is present in most of the same samples from Site 479 and is coincident with free-base and metallo-DPEP-porphyrins. The correlation between free-base DPEP (XV) and NiDPEP or 7-ethyl-7-desproprio-Ni phylloerythrin and NiDPEP is easily seen. However, the direct precursor to $\mathrm{Ni}$ phylloerythrin, namely phylloerythrin, is lacking. Since phorbide-658.5 (Table 3) tentatively has been identified as 7-ethyl-7-desproprio-meso (alt. 2-methyl-2desvinyl, or both) -pyropheophorbide-a (XIII, XIV), it appears likely that phylloerythrin (i.e., as the 7-ethyl-7desproprio-analog: XVI) forms, via aromatization of phorbide-658.5, and is more reactive to metals, thus chelating more rapidly than DPEP (XV). Alternatively, chelation may occur at the phorbide stage with rapid or concurrent aromatization yielding decarboxylated $\mathrm{Ni}$ phylloerythrin. No evidence suggests one over the other, aside from the fact that, in the 9-desoxo-phorbide series, free-base DPEP (XV) forms prior to chelation.

Schemes I and II, mentioned above (Figs. 7 and 8), present the oxidative and reductive diagenesis of chlorophyll derivatives in marine sediments as revealed by examination of Leg 64 samples. The key reaction fating tetrapyrrole-pigment survival appears to be the loss of the 10-carbomethoxy group prior to allomerization. This parallels the known in vitro chemistry of chlorophyll derivatives, in that the pyro- compounds can no longer ionize the $\mathrm{C}-10$ hydrogen prior to or concurrent with allomerization (see Hynninen, 1979; Seely, 1966).
Several stages in the diagenesis of tetrapyrrole pigments can be related to the thermal histories of the various Leg 64 sites.

Section 477-7-1, presently at 49.8 meters sub-bottom and with an in situ temperature of about $10.9^{\circ} \mathrm{C}$ (i.e., based on bottom water $T=3.5^{\circ} \mathrm{C}$ and temperature gradient $=149^{\circ} \mathrm{C} / \mathrm{km}$; site reports, this volume) was found to contain over $75 \%$ of the total tetrapyrrole pigment as free-base DPEP. Considering that defunctionalization of phorbides and subsequent aromatization to free-base DPEP (XV) is observed to occur, over geologic time (e.g., Neogene equivalency), throughout a temperature regime of about 15 to $38^{\circ} \mathrm{C}$ (Louda and Baker, 1981; this report), and that chelation overlaps aromatization (e.g., Miocene sediments, $\sim 30-45^{\circ} \mathrm{C}$; Louda and Baker, 1981: Quaternary sediments, $\sim 40^{\circ} \mathrm{C}+$; this report), it appears that the time function in the kinetics of the chelation reaction is indeed operative.

The undisturbed sedimentary sequence examined from Site 479 reveals that the three major diagenetic steps in the early geochemistry of tetrapyrrole pigments proceed in a very orderly fashion. These are defunctionalization of phorbides, aromatization, and chelation. These reactions were discussed earlier herein and are covered elsewhere (Baker and Palmer, 1978; Louda and Baker, 1981). In the present study, defunctionalization of phorbides in Quaternary sediments was found to occur at bottom-water temperatures up to about $32^{\circ} \mathrm{C}$ (see Section 479-291-5; Table 3), after which only the immediate precursor to DPEP (XV), 7-ethyl-7-desproprio-meso (alt. 2-methyl-2-desvinyl) desoxophyropheophorbide-a (i.e., "Phorbide-641" in Table 3: See XIII, XIV), remains. The defunctionalization of phorbides in these Quaternary sediments, occurring at about 3.5 to $32^{\circ} \mathrm{C}$, contrasts well with the extended period of defunctionalization found for the Pliocene and Miocene sediments from the Japan Trench inner wall, which were only at about $11^{\circ} \mathrm{C}$ (DSDP Sites 434, 435, 440; Baker and Louda, 1980a; Louda et al., 1980).

Aromatization of phorbides yielding porphyrins (see Fig. 3) was found to be most intense through a present temperature regime of about 28 to $38^{\circ} \mathrm{C}$ for Site 479 Quaternary sediments. The relative geologic youth (i.e., time) of these strata has been found to elevate the temperature required in order to elicit aromatization, when compared to sediments of lesser heat flow. That is, in the early Pleistocene to Miocene sediments studied from the Black Sea (DSDP Site 380A), aromatization was found to have occurred throughout a temperature regime of about 20 to $35^{\circ} \mathrm{C}$, and was complete by $40^{\circ} \mathrm{C}$ (from the data of Baker et al., 1978b; and Erickson, 1978). Similar results were obtained with the PlioceneMiocene sections investigated from the San Miguel Gap off California (DSDP Site 467), in that aromatization occurred within the range of about 15 to $38^{\circ} \mathrm{C}$ (Louda and Baker, 1981).

The transition from free-base to metalloporphyrins (chelation, $\mathrm{Ni}$ ) has been observed to occur between 50 and $60^{\circ} \mathrm{C}$ for the early Miocene sediments from the Tarfaya Basin, eastern Atlantic (DSDP Site 397A: from the 
data of Baker and Palmer, 1979; and von Rad, Ryan, et al., 1979). The chelation of nickel, from initiation to completion, was found to have occurred between 20 and $55^{\circ} \mathrm{C}$ in the Miocene sediments from the San Miguel Gap, California (DSDP Site 467: Louda and Baker, 1981).

Until now, we have related the diagenetic steps transforming biotic chlorophyll (pheophytin-a) into the geologic metalloporphyrins only with temperature. Because a great deal of decarboxylation appears to occur in thermally unstressed sediments (e.g., $\mathrm{T}<20^{\circ} \mathrm{C}$ ), biotic factors are implicated. Loss of other functionalities (e.g., vinyl, carbonyl) may also be related to microbial activity or in combination with such abiotic factors as Eh, $\mathrm{pH}$, degree of consolidation (water content), or the presence of mineral catalysts (e.g., clays). Integration of all biotic and abiotic forces which act upon tetrapyrrole diagenesis is a major task yet to be performed.

\section{Diagenesis of Tetraterpenoid Pigments}

All Leg 64 sections analyzed (see Tables 2 and 6) yielded markedly lower amounts of oxygen-containing carotenoids, relative to the hydrocarbon pigments (carotenes), than reported for aquatic or terrestrial plants (see Goodwin, 1976; Vallentyne, 1960). The ratio of oxygen-containing carotenoids to carotenes was found to decrease to zero within the uppermost 156.6 meters of Site 479 , whereas carotenes remained present to depths greater than 171.6 meters sub-bottom (see Table 2 and 6 ). These data indicate more-rapid destruction of the oxy- and oxo-carotenoids, relative to the carotenes (cf. Fox et al., 1944; Schwendinger and Erdman, 1963; Vallentyne, 1960). The tentative identification of several dehydro- and bisdehydro-carotenes may reflect a diagenetic dehydration of carotenols and carotene-diols, respectively. The bisdehydro-carotenes isolated from Leg 64 sediments were further classified as retro-forms (see Appendix B; Tables 6 and 8).

As with previous studies of DSDP core samples (Baker and Louda, 1980a; Brassell et al., 1980; Louda and Baker, 1981) carotenoids were found to be rapidly destroyed, as pigments, with increasing depths of burial. Much greater survival of carotenoids was found for the oxygen-minimum site (479) than at any other site investigated (see Table 2). Thus, a role as indicators of paleoenvironment (anoxic versus oxic deposition) is suggested (cf. Louda and Baker, 1981; Watts et al., 1977).

The tentative identification of mutatochrome (XXVII: 5,8 -epoxy- $\beta, \beta$-carotene) and mono-epoxy- $\beta$-carotene (XXVI: 5,6 -epoxy- $\beta, \beta$-carotene) from Leg 64 sediments at first implicates these pigments as diagenetic products. However, we were able to show the presence of mutachrome (XXVII) in fresh and 2-month postmortum cultures of the diatom Synedra sp. Thus, it appears that these epoxy carotenes are partially inherited from biotic sources, rather than totally formed in situ within these sediments. Epoxy-carotenoids have been implicated in the intra-cellular degradations of senescent plant materials (Simpson et al., 1976; and references therein). However, the formation of epoxycarotenoids, potentially leading to the formation of apo-carotenoids, should not be overlooked as a possible route of sedimentary carotenoid degradation.

Carotenoid input to the Gulf of California sediments appears to have been primarily from the Bacillariophyceae. That is, diatoxanthin, diadinoxanthin, and several carotenols and carotene-diols apparently derived from fucoxanthin dominate the oxygen-containing carotenoid assemblages isolated from Leg 64 samples.

The rapid demise of carotenoid pigments during early diagenesis reinforces, in part, the idea that these compounds serve as precursors to such hydrocarbons as toluene, iso-pentane, neo-pentane, and a series of gemdimethylalkanes present in the gasoline-range $\left(C_{4}-C_{7}\right)$ isolates from various immature marine sediments (see Hunt and Whelan, 1978a, b; Hunt et al., 1980).

\section{Geochemistry of Perylene}

Perylene was isolated as a ubiquitous component of all Leg 64 samples analyzed, except for certain sections near igneous sills (see Table 2). Perylene may have been present in trace amounts even in these latter strata, but the absence of tetrapyrrole pigments prompted an end to those analyses.

Within roughly the uppermost 125 meters of sediment at Site 479 , minima in perylene concentrations were found to be associated with maxima in $\mathrm{H}_{2} \mathrm{~S}$ concentrations. Conversely, a large maximum in perylene abundance was found to correspond with a minimum in $\mathrm{H}_{2} \mathrm{~S}$ content. This was interpreted as reflecting the influence of oxic conditions near the sediment/water interface as partially controlling perylene formation and/or the input of unknown perylene precursors. Unknown perylene-based pigments, possibly present in aerobic or micro-aerophilic marine benthic microbes, were hypothesized as perylene precursors. Much study is yet required in order to solve the enigma of perylene in non-contemporaneous marine sediments.

Whatever the exact source of perylene, the alkylation of perylene is suggested as an indicator of geothermal stress. That is, near-surface sediments from the sitesurvey locale (Site 10G) and Site 474 contained only perylene (C-20) itself. With increased depth of burial, and concurrent increases of in situ temperature, the alkylated $\left(C_{1}, C_{2}\right.$, etc.) perylenes were found to have formed. In the present case, the region of most intense perylene alkylation was found to occur with in situ temperatures of 40 to $50^{\circ} \mathrm{C}$ for these Quaternary to very late Pliocene sediments. This contrasts well with perylene alkylation observed previously to occur throughout a temperature profile of 35 to $40^{\circ} \mathrm{C}$ for the Miocene sediments investigated from the San Miguel Gap, California borderlands (DSDP Site 479; Louda and Baker, 1981). The alkylation of perylene within sediments from Site 481 was found to have been accelerated and partially randomized because of the presence of igneous intrusions.

\section{ACKNOWLEDGMENTS}

The assistance of Mr. Ron Lane, Mr. Churchill Barton, and Ms. Cheryl Marshall during initial sample preparation and routine laboratory duties is appreciated. Mr. Lane is also thanked for determining the percent water of all samples. 
Dr. Karl S. Schorno of Phillips Petroleum, Bartlesville, Oklahoma, is thanked for determinations of organic-carbon contents for the Leg 64 Guaymas Basin site survey (S.I.O. Leg 3, Sites 10G and $18 \mathrm{G})$ samples.

Dr. Bernd R. T. Simoneit and Ms. Monica Mazurek are gratefully acknowledged for providing the surface samples from the Guaymas Basin (S.I.O. Leg 3, Sites 10G and 18G).

Dr. Pam Zelmer of the University of Miami is thanked for her critical review of this manuscript.

The authors studies are funded by grant (OCE-7913258) from the National Science Foundation whose support is sincerely appreciated.

\section{REFERENCES}

Aizenshtat, Z., 1973. Perylene and its geochemical significance. Geochim. Cosmochim. Acta, 37:559-567.

Baker, E. W., 1970. Tetrapyrrole Pigments. In Bader, R. G., Gerard, R. D., et al., Init. Repts. DSDP, 4: Washington (U.S. Govt. Printing Office), 431-438.

Baker, E. W., and Corwin, A., 1966. Mesoporphyrin-IX. In Maehly, A. C. (Ed.), Biochemical Preparations (Vol. 11): New York (Wiley), 76-79.

Baker, E. W., Corwin, A. H., Klesper, E., and Wei, P. E., 1968. Deoxophylloerythroetioporphyrin. J. Org. Chem., 33:3144-3148.

Baker, E. W., and Louda, J. W., 1980a. Products of chlorophyll diagenesis in Japan Trench sediments. II. DSDP/IPOD Sites 438439 and 440. In Scientific Party et al., Init. Repts. DSDP, 56, 57, Pt. 2: Washington (U.S. Govt. Printing Office), 1397-1408.

1980b. Geochemistry of Tetrapyrrole Pigments in Sediments of the North Philippine Sea: DSDP/IPOD Leg 58. In Klein, G. deV., Kobayashi, K., et al., Init. Repts. DSDP, 58: Washington (U.S. Govt. Printing Office), 737-739.

1981. Perylene in marine sediments: a potentially useful geothermal stress indicator of problematic source. In 181st National ACS Meeting, Division of Geochemistry, Atlanta, Georgia, March 29-April 3, 1981.

Baker, E. W., and Palmer, S. E., 1978. Geochemistry of porphyrins. In Dolphin, D. (Ed.), The Porphyrins (Vol. 1): New York (Academic Press), 486-552.

1979. Chlorophyll diagenesis in IPOD Leg 47A, Site 397. core samples. In von Rad, U., Ryan, W. B. F., et al., Init. Repts. DSDP, 47, Pt. 1: Washington (U.S. Govt. Printing Office), 547-551.

Baker, E. W., Palmer, S. E., and Huang, W. Y., 1978a. Intermediate and late diagenetic tetrapyrrole pigments, Leg 4i: Cape Verde Rise and Basin. In Lancelot, Y., Seibold, E., et al., Init. Repts. DSDP, 41: Washington (U.S. Govt. Printing Office), 825-837.

1978b. Early and intermediate chlorophyll diagenesis of Black Sea sediments: Sites 379, 380, and 381. In Ross, D. A., Neprochnov, Y. P., et al., Init. Repts. DSDP, 42, Pt: 2: Washington (U.S. Govt. Printing Office), 707-715.

Baker, E. W., Palmer, S. E., Huang, W. Y., and Rankin, J. G., 1978. Mass and electronic paramagnetic resonance spectrometric analyses of selected organic components of Cretaceous shales of marine origin. In Uden, P. C., Siggia, S., and Jensen, H. B. (Eds.), Analytical Chemistry of Liquid Fuel Sources: Tar Sands, Oil Shale, Coat, and Petroleum: Washington (Am. Chem. Soc.), pp. $159-180$

Baker, E. W., and Smith, G. D., 1973. Chlorophyll derivatives in sediments, Site 147. In Heezen, B. C., MacGregor, I. D., et al., Init. Repts. DSDP, 20: Washington (U.S. Govt. Printing Office), 943-946.

Blumer, M., and Omenn, G. S., 1961. Fossil porphyrins: uncomplexed chlorins in a Triassic sediment. Geochim. Cosmochim. Acta, 25:81-90.

Blumer, M., and Rudrum, M., 1970. High molecular weight fossil porphyrins: evidence for monomeric and dimeric tetrapyrroles of about 1100 molecular weight. J. Inst. Pet., 56:99-106.

Bonnett, R., Mallams, A. K., Spark, A. A., Tee, J. L., Weedon, B. C. L., and McCormick, A., 1969. Carotenoids and related compounds. Part XX. Structure and reactions of fucoxanthin. $J$. Chem. Soc., 1969(3):429-454.

Brassell, S. C., Comet, P. A., Eglinton, G., Isaacson, P. J., McEvoy, Maxwell, J. R., Thomson, I. D., Tibbetts, P. J. C., and Volkman, J. K., 1980. Preliminary lipid analyses of Sections 440A-7-6,
440B-3-5, 440-8-4, 440B-68-2, and 436-11-4: Legs 56 and 57, Deep Sea Drilling Project. In Scientific Party, et al., Init. Repts. DSDP, 56, 57, Pt. 2: Washington (U.S. Govt. Printing Office), $1367-1390$.

Cardoso, J. N., Wardroper, A. M. K., Watts, C. D., Barnes, P. J., Maxwell, J. R., Eglinton, G., Mound, D. G., and Speers, G. C., 1978. Preliminary organic geochemical analysis, Site 391, Leg 44 of the Deep Sea Drilling Project. In Benson, W. E., Sheridan, R. E., et al., Init. Repts. DSDP, 44: Washington (U.S. Govt. Printing Office), 617-623.

Chichester, C. O., and Nakayama, T. O. M., 1965. Pigment changes in senescent and stored tissue. In Goodwin, T. W. (Ed.), Chemistry and Biochemistry of Plant Pigments: London (Academic Press), pp. $439-457$.

Davies, B. H., 1965. Analysis of carotenoid pigments. In Goodwin, T. W. (Ed.), Chemistry and Biochemistry of Plant Pigments: London (Academic Press), pp. 489-532.

Day, C., and Erdman, J. G., 1963. Ionene: a thermal degradation product of $\beta$-carotene. Science, 141:808.

Erikson, A. J., and Von Herzen, R. P., 1978. Downhole temperature measurements and heat flow data in the Black Sea-DSDP Leg 42B. In Ross, D. A., Neprochnov, Y. P., et al., Init. Repts. DSDP, 42, Pt. 2: Washington (U.S. Govt. Printing Office), 1085-1104.

Fiksdahl, A., Mortensen, J. T., and Liaaen-Jensen, S., 1978. Highpressure liquid chromatography of carotenoids. J. Chromatog., 157:111-117.

Fischer, H., and Stern, A., 1940. The Chemistry of Pyrroles (Vol. 2): Leipzig (Akad. Verlagsg.).

Foppen, F. H., 1971. Tables for the identification of carotenoids. Chromatogr. Rev., 14:133-298.

Fox, D. L., 1948. Some biochemical aspects of marine carotenoids. In Zechmeister, L. (Ed.), Progress in the Chemistry of Organic Natural Products (Vol. 5): New York (Springer-Verlag), 20-39.

Fox, D. L., Updegraff, D. M., and Novelli, G. D., 1944. Carotenoid pigments in the ocean floor. Arch. Biochem., 5:1-23.

Fuhrhop, J. H., and Smith, R. M., 1975. Laboratory methods. In Smith, K. M. (Ed.), Porphyrins and Metalloporphyrins: Amsterdam (Elsevier), pp. 757-889.

Galimov, E., Kodina, L. A., Shirinsky, V. G., Drozdova, T. V., Generalova, V. N., Bogachova, M. P., Chinyonov, V. A., and Bannikova, L. A., 1980. A study of organic matter from deep oceanic bore holes, Deep Sea Drilling Project Sites 415 and 416, in the Moroccan Basin. In Lancelot, Y., Winterer, E. L., et al., Init. Repts. DSDP, 50: Washington (U.S. Govt. Printing Office), 575-603.

Goedheer, J. C., 1966. Visible absorption and fluorescence of chlorophyll and its aggregates in solution. In Vernon, L. P., and Seely, G. F. (Eds.), The Chlorophylls: New York (Academic Press), pp. 147-184.

Goodwin, T. W., 1976. Distribution of carotenoids. In Goodwin, T. W. (Ed.), Chemistry and Biochemistry of Plant Pigments (2nd ed.) (Vol. 1): London (Academic Press), 225-261.

Hager, A., and Stransky, H., 1970. Das Carotinoidmuster und die Verbreitung des lichtinduzierten Xanthophyllcyclus in verschiedenen Algenklassen. III. Grunalgen. Arch. Mikrobiol., 72: 68-83.

Hajibrahim, S. K., Tibbetts, P. J. C., Watts, C. D., Maxwell, J. R., Eglinton, G., Colin, H., and Guiochon, G., 1978. Analysis of carotenoid and porphyrin pigments of geochemical interest by HPLC. Analyt. Chem., 50:549-553.

Hodgson, G. W., and Baker, B. L., 1967. Spectra of selected geochemically significant porphyrins and chlorins. Chem. Geol., 2: $187-1198$.

Hodgson, G. W., and Peake, E., 1961. Metal chlorin complexes in Recent sediments as initial precursors to petroleum porphyrin pigments. Nature, 191:766-767.

Holt, A., 1959. Reduction of chlorophyllides, chlorophylls, and chlorophyll derivatives by sodium borohydride. Plant Physiol., $34: 310-314$

Hunt, J. M., Miller, R. J., and Whelan, J. K., 1980. Formation of $\mathrm{C}_{4}-\mathrm{C}_{7}$ hydrocarbons from bacterial degradation of naturally occurring terpenoids. Nature, 288:577-578.

Hunt, J. M., and Whelan, J. K., 1978a. Dissolved gases in Black Sea sediments. In Ross, D. A., Neprochnov, Y. P., et al., Init. 
Repts. DSDP, 42, Pt. 2: Washington (U.S. Govt. Printing Office), 661-665.

1978b. Light hydrocarbon in sediments of DSDP Leg 44 Holes. In Benson, W. E., Sheridan, R. E., et al., Init. Repts. DSDP, 44: Washington (U.S. Govt. Printing Office), 651-652.

Hynninen, P., 1979. Application of elution analysis to the study of chlorophyll transformations of column chromatography on sucrose. J. Chromatog., 175:75-88.

Jones, I. D., White, R. C., Gibbs, E., and Denard, C. D., 1968. Absorption spectra of copper and zinc complexes of pheophytins and pheophorbides. J. Agr. Food Chem., 16:80-83.

Krinsky, N. I., 1963. A relationship between partition coefficients of carotenoids and their functional groups. Analyt. Bichem., 6: 293-302.

Krinsky, N. I., and Goldsmith, T. H., 1960. The carotenoids of the flagellated alga, Euglena gracilis. Arch. Biochem. Biophys., 91: 271-279.

Liaaen-Jensen, S., 1971. Isolation, reactions. In Isler, B. (Ed.), Carotenoids: Basel (Birkhauser-Verlag), pp. 61-188.

Louda, J. W., and Baker, E. W., 1980. Incorporation of the various chlorophylls into marine sediments and terrestrial peats. 179th National A.C.S. Meeting, Division of Geochemistry, Houston, Texas, March 23-28, 1980.

1981. Geochemistry of tetrapyrrole, carotenoid, and perylene pigments in sediments from the San Miguel Gap (Site 467) and Baja California borderlands (Site 471): DSDP/IPOD Leg 63. In Haq, B., Yeats, R. S., et al., Init. Repts. DSDP, 63: Washington (U.S. Govt. Printing Office), 785-818.

Louda, J. W., Palmer, S. E., and Baker, E. W., 1980. Products of chlorophyll diagenesis in Japan Trench sediments. I. Deep Sea Drilling Project Sites 434, 435, and 436. In Scientific Party, et al., Init. Repts. DSDP, 56, 57, Pt. 2: Washington (U.S. Govt. Printing Office), 1391-1396.

Mackenzie, A. S., Quirke, J. M. E., and Maxwell, J. R., 1980. Molecular parameters of maturation in the Toarcian shales, Paris Basin, France-II. Evolution of metalloporphyrins. In Douglas, A. G., and Maxwell, J. R. (Eds.), Advances in Organic Geochemistry1979. Oxford (Pergamon Press), pp. 239-248.

Orr, W. L., Emery, K. O., and Grady, J. R., 1958. Preservation of chlorophyll derivatives in sediments off Southern California. Bull. Am. Assoc. Petrol. Geol., 42:925-958.

Palmer, S. E., and Baker, E. W., 1978. Copper porphyrins in deepsea sediments: a possible indicator of oxidized terrestrial organic matter. Science, 201:49-51.

Petracek, F. J., and Zechmeister, L., 1956. Determination of partition coefficients of carotenoids as a tool in pigment analysis. Analyt. Chem., 28:1484-1485.

Purcell, A. E., 1958. Partition separation of carotenoids by silicamethanol columns. Analyt. Chem., 30:1049-1051.

Sato, S., 1980. Diagenetic alteration of organic matter in Leg 57 sediments, Deep Sea Drilling Project. In Scientific Party, et al., Init. Repts. DSDP, 56, 57, Pt. 2: Washington (U.S. Govt. Printing Office), $1305-1312$.

Schnurman, R., Maddanis, W. F., and Barlow, M. C., 1953. Spectrometric identification of polynuclear aromatic components in high-boiling petroleum fractions. Analyt. Chem., 25:1010-1013.

Schwendinger, R. B., and Erdman, J. G., 1963. Carotenoids in sediments as a function of environment. Science, 141:808-810.

Scientific Party, 1980. Introduction and Site Reports (DSDP/IPOD Legs 56-67). In Scientific Party, Init. Repts. DSDP, 56, 57, Pt. 1: Washington (U.S. Govt. Printing Office), 1-446.
Seely, G. R., 1966. The structure and chemistry of functional groups. In Vernon, L. P., and Seely, G. R. (Eds.), The Chlorophylls: New York (Academic Press), pp. 67-110.

Simoneit, B. R. T., Mazurek, M. A., Brenner, S., Crisp, P. T., and Kaplan, I. R., 1979. Organic geochemistry of Recent sediments from Guaymas Basin, Gulf of California. Deep-Sea Res., 26A: 879-891.

Simpson, K. L., Lee, T-C., Rodriquez, D. B., and Chichester, C. O., 1976. Metabolism in senescent and stored tissues. In Goodwin, T. W. (Ed.), Chemistry and Biochemistry of Plant Pigments (2nd ed.), (Vol. 1): London (Academic Press), 780-842.

Smith, J. H. C., and Benitz, A., 1955. Chlorophylls: analysis in plant materials. In Paech, K., and Tracey, M. V. (Eds.), Modern Methods of Plant Analysis (Vol. 4): Berlin (Springer-Verlag), pp. 142-196.

Smith, R., and Kevin, M., 1975. General features on the structure and chemistry of porphyrin compounds. In Smith, K. M. (Ed.), Porphyrins and Metalloporphyrins: Amsterdam (Elsevier), pp. 3-28.

Straub, O., 1971. Lists of natural carotenoids. In Isler, O. (Ed.), Carotenoids: Basel (Birkhauser-Verlag), pp. 771-850.

Thomson, R. H., 1976. Quinones, nature, distribution and biosynthesis. In Goodwin, T. W. (Ed.), Chemistry and Biochemistry of Plant Pigments (2nd ed.) (Vol. 1): London (Academic Press), pp. 527-559.

Treibs, A., 1936. Chlorophyll and hemin derivatives in organic mineral substances. Angew. Chem., 49:682-686.

Ultraviolet Atlas of Organic Compounds, Volume III, 1967: New York (Plenum Press), Perylene-Spectrum $\triangle E 6 / 14$.

Vallentyne, J. R., 1960. Fossil pigments. In Allen, M. B. (Ed.), Comparative Biochemistry of Photoreactive Systems: New York (Academic Press), pp. 83-105.

Vetter, W., Englert, G., Rigassi, N., and Schwieter, V., 1971. Spectroscopic methods. In Isler, O. (Ed.), Carotenoids: Basel (Birkhauser-Verlag), pp. 189-266.

von Rad, U., Ryan, W. B. F., et al., 1979. Site 397. In von Rad, U., Ryan, W. B. F., et al., Init. Repts. DSDP, 47, Pt. 1: Washington (U.S. Govt. Printing Office), 17-218.

Wakeham, S. G., Schaffner, C., and Giger, W., 1980. Polycyclic aromatic hydrocarbons in Recent lake sediments-II. Compounds derived from biogenic precursors during early diagenesis. Geochim. Cosmochim. Acta, 44:415-429.

Wakeham, S. G., Schaffner, C., Giger, W., Boon, J. J., and DeLeeuw, J. W., 1979. Perylene in sediments from the Namibian Shelf. Geochim. Cosmochim. Acta 43:1141-1144.

Watts, C. D., and Maxwell, J. R., 1977. Carotenoid diagenesis in a marine sediment. Geochim. Cosmochim. Acta, 41:493-497.

Watts, C. D. Simoneit, B. R., Maxwell, J. R., and Ragot, J. P., 1977. The quincyte pigments. A novel series of fossil "dyes" from an Eocene sediment. In Campos, R., and Goni, J. (Eds.), Advances in Organic Geochemistry-1975: Madrid (Enadisma), pp. 223-235.

Weedon, B. C. L., 1969. Spectroscopic methods for elucidating the structures of carotenoids. In Zechmeister, L. (Ed.), Progress in the Chemistry of Organic Natural Products (Vol. 27): New York (Springer-Verlag), 81-130.

Yentsch, C. S., 1965. Distribution of chlorophyll and phaeophytin in the open ocean. Deep-Sea Res., 12:653-666.

Zechmeister, L., 1960. Cis-trans isomeric carotenoid pigments. In Zechmeister, L. (Ed.), Progress in the Chemistry of Organic Natural Products (Vol. 18): New York (Springer-Verlag), 223-349. 
APPENDIX A

Structure of Tetrapyrrole Pigments

Phorbides and DPEP-Type Porphyrins

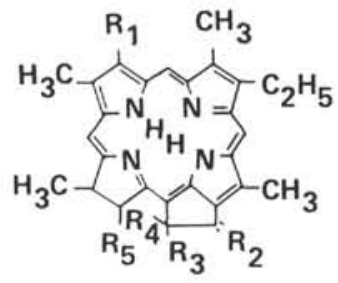

\begin{tabular}{|c|c|c|c|c|c|c|}
\hline \multicolumn{2}{|c|}{ Compound } & \multirow{2}{*}{$\frac{\mathrm{R}_{1}}{\mathrm{CH}=\mathrm{CH}_{2}}$} & \multirow{2}{*}{$\begin{array}{l}R_{2} \\
=0\end{array}$} & \multirow{2}{*}{$\frac{\mathrm{R}_{3}}{-\mathrm{COOCH}_{3}}$} & \multirow{2}{*}{$\begin{array}{l}\mathrm{R}_{4} \\
-\mathrm{H}\end{array}$} & \multirow{2}{*}{$\frac{\mathrm{R}_{5}{ }^{*}}{-\mathrm{CH}_{2} \mathrm{CH}_{2} \mathrm{COO} \text {-Phytyl }}$} \\
\hline 1 & Pheophytin-a & & & & & \\
\hline II & Pyropheophytin-a & $-\mathrm{CH}=\mathrm{CH}_{2}$ & $=0$ & $\cdot H$ & $\cdot H$ & - $\mathrm{CH}_{2} \mathrm{CH}_{2} \mathrm{COO}$-Phytyl \\
\hline III & 10-oxy-pheophytin-a ("allomerized") & $\cdot \mathrm{CH}=\mathrm{CH}_{2}$ & $=0$ & $-\mathrm{COOCH}_{3}$ &. $\mathrm{OH}$ & - $\mathrm{CH}_{2} \mathrm{CH}_{2} \mathrm{COO}$-Phytyl \\
\hline IV & Pheophorbide-a & $\mathrm{CH}=\mathrm{CH}_{2}$ & $=0$ & $-\mathrm{COOCH}_{3}$ & $\cdot+\mathrm{H}$ & $-\mathrm{CH}_{2} \mathrm{CH}_{2} \mathrm{COOH}$ \\
\hline V & Pyropheophorbide-a & $-\mathrm{CH}=\mathrm{CH}_{2}$ & $=0$ & $-H$ & $\cdot \mathrm{H}$ & $-\mathrm{CH}_{2} \mathrm{CH}_{2} \mathrm{COOH}$ \\
\hline VI & 10-oxy-pheophorbide-a ("allomerized") & $\cdot \mathrm{CH}=\mathrm{CH}_{2}$ & $=0$ & $\cdot \mathrm{COOH}_{3}$ &. $\mathrm{OH}$ & $-\mathrm{CH}_{2} \mathrm{CH}_{2} \mathrm{COOH}$ \\
\hline VII & 2-acetyl-2-desvinyl-pyropheophytin-a & $-\mathrm{COCH}_{3}$ & $=0$ & $\cdot H$ & $-H$ & - $\mathrm{CH}_{2} \mathrm{CH}_{2} \mathrm{COO}$-Phytyl \\
\hline VIII & 7-ethyl-7-desproprio-pyropheophorbide-a & $-\mathrm{CH}=\mathrm{CH}_{2}$ & $=0$ & $\cdot H$ & $\cdot H$ & $-\mathrm{CH}_{2} \mathrm{CH}_{3}$ \\
\hline IX & $\begin{array}{l}\text { 7-ethyl-7-desproprio-desoxo- } \\
\text { pyropheophorbide-a }\end{array}$ & $\mathrm{CH}=\mathrm{CH}_{2}$ & $\cdot H \cdot \cdot H$ & $-H$ & $-H$ & $-\mathrm{CH}_{2} \mathrm{CH}_{3}$ \\
\hline$x$ & $\begin{array}{l}\text { 7-ethyl-7-desproprio-meso- } \\
\text { pyropheophorbide-a }\end{array}$ & $-\mathrm{CH}_{2} \mathrm{CH}_{3}$ & $=0$ & $\cdot H$ & $\cdot H$ & $-\mathrm{CH}_{2} \mathrm{CH}_{3}$ \\
\hline XI & $\begin{array}{l}\text { 7-ethyl-7-desproprio-2-methyl-2- } \\
\text { desvinyl-pyropheophorbide-a }\end{array}$ & $-\mathrm{CH}_{3}$ & $=0$ & $\cdot H$ & $\cdot H$ & $-\mathrm{CH}_{2} \mathrm{CH}_{3}$ \\
\hline XII & desoxo-mesopyropheophorbide-a & $\cdot \mathrm{CH}_{2} \mathrm{CH}_{3}$ & $\mathrm{H}, \mathrm{H}$ & $-H$ & $\cdot H$ & $-\mathrm{CH}_{2} \mathrm{CH}_{2} \mathrm{COOH}$ \\
\hline XIII & $\begin{array}{l}\text { 7-ethyl-7-desproprio-meso- } \\
\text { desoxopyropheophorbide-a }\end{array}$ & $-\mathrm{CH}_{2} \mathrm{CH}_{3}$ & $\mathrm{H}, \mathrm{H}$ & $\cdot H$ & $\cdot H$ & $-\mathrm{CH}_{2} \mathrm{CH}_{3}$ \\
\hline XIV & $\begin{array}{l}\text { 7-ethyl-7-desproprio-2-methyl- } \\
\text { 2-desvinyl-desoxopyropheophorbide-a }\end{array}$ & $-\mathrm{CH}_{3}$ & $\mathrm{H}, \mathrm{H}$ & $\cdot H$ & $\cdot H$ & $-\mathrm{CH}_{2} \mathrm{CH}_{3}$ \\
\hline XV & Desoxophylloerythroetioporphyrin & $\cdot \mathrm{CH}_{2} \mathrm{CH}_{3}$ & $\mathrm{H}, \mathrm{H}$ & $-H$ & $\cdot H$ & - $\mathrm{CH}_{2} \mathrm{CH}_{3}$; plus 7,8-didehydro \\
\hline XVI & 7-ethyl-7-desproprio-phylloerythrin & $-\mathrm{CH}_{2} \mathrm{CH}_{3}$ & $=0$ & $\cdot H$ & $\cdot \mathrm{H}$ & $-\mathrm{CH}_{2} \mathrm{CH}_{3}$; plus 7,8-didehydro \\
\hline
\end{tabular}

"Phytol ester $=\mathrm{C}_{20} \mathrm{H}_{40} \mathrm{O}$; alternately may be converted to dihydrophytol ester $\left(\mathrm{C}_{20} \mathrm{H}_{42} \mathrm{O}\right.$ ); see text.

Chlorins, Purpurins, and Etio-Porphyrins

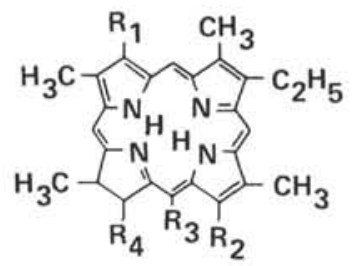

\begin{tabular}{llll}
\multicolumn{2}{l}{ Compound } & \multicolumn{1}{l}{$\mathrm{R}_{2}$} & $\mathrm{R}_{3}$ \\
\hline XVII & Chlorin-e 6 & $\mathrm{CH}_{2} \mathrm{COOH}$ & $-\mathrm{COOH}$ \\
XVIII & Chlorin-e 4 & $-\mathrm{CH}_{3}$ & $-\mathrm{COOH}$ \\
XIX & Purpurin018 & $\mathrm{O}=\mathrm{C}-\mathrm{O}-\mathrm{C}=\mathrm{O}$ \\
XXI & Purpin-7 & $-\mathrm{COCOOH}$ & $-\mathrm{COOH}$ \\
& ETIO-porphyrin-III & $-\mathrm{C}_{2} \mathrm{H}_{5}$ & $-\mathrm{H}$; plus 7,8-didehydro \\
\hline
\end{tabular}

$\mathrm{R}_{1}{ }^{*}$ equals vinyl for compounds as given: Possible derivatives are; meso, $R_{1}$ equals ethyl and 2-methyl 2.desvinyl, $R_{1}$ equals methyl.

$\mathrm{R}_{4}{ }^{*}$ equals proprionic acid for compounds as given: Possible analogs are phytyl esters, dihydrophytyl esters, and 7-ethyl-7-desproprio-compounds. 
APPENDIX B

Structure of Tetraterpenoid Pigments

Structural

Numeral (see Straub, 1971)

\begin{tabular}{|c|c|c|}
\hline$x \times 11$ & all-trans- $\beta$-carotene & $\beta, \beta$-carotene \\
\hline$X X I I I$ & $15,15^{\prime}$-cis- $\beta$-carotene & 15 -cis- $\beta, \beta$-carotene \\
\hline XXIV & dehydro- $\beta$-carotene & 3,4-didehydro- $\beta, \beta$-carotene \\
\hline$x \times V$ & retro-dehydro- $\beta$-carotene & $4^{\prime}, 5^{\prime}$-didehydro- $4^{\prime}, 5^{\prime}$-retro- $\beta, \beta$-carotene \\
\hline$X X V I$ & $\beta$-carotene-monoepoxide & 5,6-epoxy-5,6-dihydro- $\beta, \beta$-carotene \\
\hline$X X V I I$ & mutatochrome & 5,8-epoxy-5,8-dihydro- $\beta, \beta$-carotene \\
\hline$X X V I I I$ & echinenone & $\beta, \beta$-carotene-4-one \\
\hline $\mathrm{XXIX}$ & canthaxanthin & $\beta, \beta$-carotene- $4,4^{\prime}$-dione \\
\hline$x \times x$ & isocryptoxanthin & $\beta, \beta$-carotene-4-ol \\
\hline$x \times X I$ & $\beta$-cryptoxanthin & $\beta, \beta$-carotene-3-ol \\
\hline$x \times x I 1$ & zeaxanthin & $\beta, \beta$-carotene-3,3'-diol \\
\hline$x \times X I I I$ & diatoxanthin & 7,8-didehydro- $\beta, \beta$-carotene-3,3'-diol \\
\hline XXXIV & diadinoxanthin & 5,6-epoxy-7', $8^{\prime}$-didehydro-5,6-dihydro- $\beta, \beta$-carotene-3,3'-diol \\
\hline$x \times x y$ & fucoxanthin & $\begin{array}{l}\text { 5,6-epoxy-3,3',5'-trihydroxy- } 6^{\prime}, 7^{\prime} \text {-didehydro-5,6,7,8,5',6'- } \\
\text { hexahydro- } \beta, \beta \text {-carotene } 8 \text {-one } 3^{\prime} \text {-acetate }\end{array}$ \\
\hline
\end{tabular}

XXII

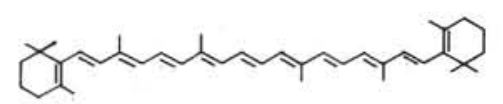

XXIV<smiles>CC(C)=CC=CC=C(C)C=CC=CC1=C(C)CCCC1(C)C</smiles>

XXVI

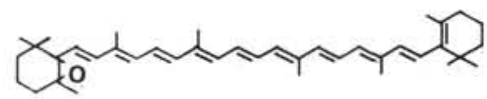

XXVIII

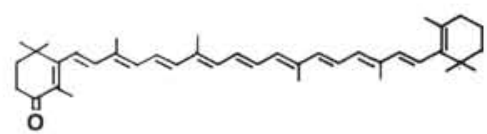

$x x x$

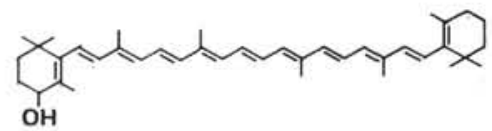

XXXII<smiles>CC=C(C)C=CC=CC(C)=CC=CC=CC=CC(C)=CC=CC1=C(C)CC(O)CC1C</smiles><smiles>[X]C([R])=O</smiles>

XXIII

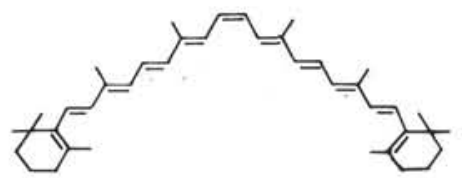

XXV

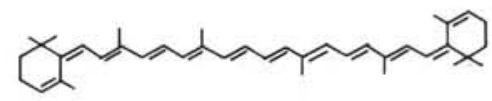

XXVII

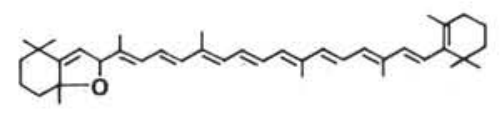

$\operatorname{XXIX}$

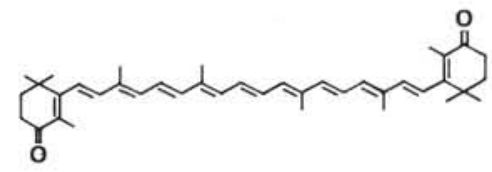

$\mathrm{XXXI}$<smiles>CC1=C(C)C(C)CC(O)C1</smiles>

XXXIII

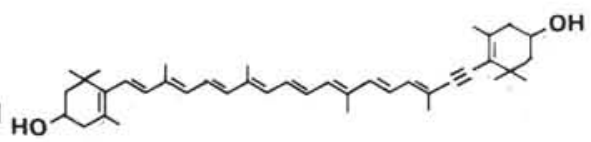

$x \times x$

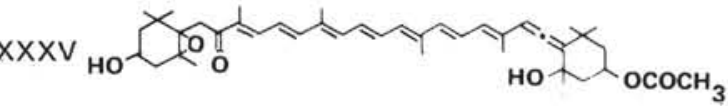

